\title{
Early Pennsylvanian to early Permian (Bashkirian-Asselian) miospore and pollen assemblages of the Czech part of the Intra-Sudetic Basin
}

\author{
JiŘí BeK \& StANisLav OpluštIL
}

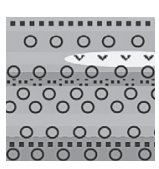

\begin{abstract}
Unpublished data resulting from extensive palynological investigation of coal and carbonaceous rocks from more than thirty boreholes, drilled in the Czech sector of the Intra-Sudetic Basin in the second half of the $20^{\text {th }}$ century, were taxonomically upgraded and analysed for stratigraphic and systematic evaluation. In total 78 genera and 322 miospore and pollen species have been recorded within a radioisotopically constrained $\sim 21 \mathrm{Ma}$ long interval from middle Bashkirian to early Asselian times, i.e. between 318 and 297 Ma. The miospore and pollen assemblages of coal seams are characteristic by the occurrence of stratigraphically important genera (e.g. Waltzispora, Radiizonates, Tripartites, Kosankeisporites, Gillespieisporites, Cadiospora, Angulisporites, Latensina, Lueckisporites, Spinosporites) and taxa recorded only within each member with the combination of quantitative data. Five new palynozones of the basin are recognised. All miospore and pollen taxa are divided into categories based on their plant affinity for the comparison of palynological and macrofloral records in terms of the diversity and vegetation patterns based on the combination of unpublished palynological and freshly published plant fossil records. - Key words: palynology, spores and pollen, Intra-Sudetic Basin, Pennsylvanian.
\end{abstract}

Bek, J. \& Opluštil, S. 2021. Early Pennsylvanian to early Permian (Bashkirian-Asselian) miospore and pollen assemblages of the Czech part of the Intra-Sudetic Basin. Bulletin of Geosciences 96(3), 341-379 (15 figures, 3 tables, appendix, electronic supplement). Czech Geological Survey, Prague. ISSN 1214-1119. Manuscript received February 28, 2020; accepted in revised form April 26, 2021; published online May 23, 2021; issued July 4, 2021.

Jiři Bek, Department of Palaeoecology and Palaeobiology, Institute of Geology v.v.i., Academy of Sciences, Rozvojová 269, 16500 Prague 6, Czech Republic; mrbean@gli.cas.cz • Stanislav Opluštil, Institute of Geology and Palaeontology, Faculty of Science, Charles University, Albertov 6, 12843 Prague 2, Czech Republic

The Intra-Sudetic Basin located along the Czech-Polish border is one of the Late Palaeozoic continental basins of Variscan Europe. It is characterised by a long depositional history ranging from late Viséan to early Triassic times. While the macrofloral record from the Czech part of the basin spans a period from the late Viséan to the Asselian (Opluštil et al. 2017), available palynological data cover an interval from early Bashkirian (early Pennsylvanian) to the Asselian (early Permian). The basin bears economically significant coal deposits exploited systematically since the beginning of the $19^{\text {th }}$ century (Tásler et al. 1979) to the closure of the last coal mine in 2009. Palaeontological research was a common part of the borehole and underground mine exploration during the second half of the $20^{\text {th }}$ century. However, nearly all data remained archived in the form of short unpublished reports. The only exception is a monograph on the Czech part of the basin prepared by Tásler et al. (1979) and later by Pešek et al. (2001) and Pešek (2004), where the palaeontological data are performed with a low resolution of individual members and does not include all the identified taxa. In this paper we focus on previously unpublished palynological research and attempt to assemble all existing palynological data from the Czech part of the basin to provide a complete list of taxa and their precise stratigraphic ranges. This list, in turn, serves as a base for an analysis of the diversity of palynological assemblages and their comparison with macroflora diversity in the same stratigraphic intervals (Opluštil et al. 2017). Available CA-ID TIMS radioisotopic ages of zircons from intercalated volcaniclastic beds in the Czech part of the basin further allow for the calibration of palynozones and biotic events marked by significant changes in palynofloras and, in turn, in macrofloras (Opluštil et al. 2016a, b).

\section{History of palaeontological research of the Czech part of the Intra-Sudetic Basin}

The history of palaeontological research of the basin starts in the first half of the $19^{\text {th }}$ century with the onset of systematic coal mining in the area. These early research activities included geological, lithostratigraphical and 
palaeontological observations and focused mainly on development of basin-wide lithostratigraphy. Fossil record served as an important tool for correlation of fossiliferous strata, mostly coal groups and lacustrine horizons. The thorough overview of history of the research in the basin provided Tásler et al. (1979), Pešek et al. (2001) and Opluštil et al. (2017).

The first megaspore research from the Czech part of the Intra-Sudetic Basin was published by Zerndt (1937) and the last by Kaiserová (1960). The review of dispersed megaspores and a short summary of some miospore results have been published by Tásler et al. (1979). All other reports, i.e. sources of data of dispersed miospore and pollen assemblages were written by Valterová $(1965$, 1967a-i, 1968a-d, 1969a-d, 1970, 1972, 1974, 1976, 1977a, b, 1978, 1979a-h, 1980a-e, 1981a-c, 1982a-e, 1984a, b, 1986a-n) in the form of short manuscripts, which are parts of the unpublished well reports. A summary of dispersed miospore and pollen assemblages; however, was published by Pešek et al. (2001). In situ spores were recently described from some fructifications collected in the basin (Bek \& Opluštil 2004, Bek et al. 2008 and Opluštil et al. 2009).

\section{Geology of the Czech part of the Intra-Sudetic Basin (CPISB)}

The Intra-Sudetic Basin consists of the eastern part of a large complex of Late Palaeozoic continental basins of the Bohemian Massif (Fig. 1). About two-thirds of this $1800 \mathrm{~km}^{2}$ basin is situated in Poland, the rest is on Czech territory (Fig. 1). The sedimentation in the basin started in late Viséan and including several hiatuses continued for over $80 \mathrm{Ma}$ until the Triassic (Tásler et al. 1979, Opluštil et al. 2017). Detailed overview of depositional history is described by Opluštil et al. (2016a, 2017). Here we will only provide a brief overview of the basin's lithostratigraphy (Fig. 1). Late Viséan to early Namurian coarse-grained alluvial deposits of the Blazkow Formation are the oldest sediments from the Czech part of the basin (Opluštil et al. 2017). After a short break, sedimentation resumed around late Namurian times by fluvial, bedload-dominated facies of the Žaclér̆ Formation. This deposition would continue until middle Westphalian. These coal-bearing units (Tásler et al. 1979) are after another short break, followed by late Westphalian to middle Stephanian fluvial red beds of the Odolov Formation, with several embedded grey coal-bearing intervals (Fig. 1). The overlying Chvaleč Formation is also mainly a red bed complex with intercalated lacustrine strata of thin coals (Tásler et al. 1979) spanning the late Stephanian (late Gzhelian) and early Permian (Asselian). Succession continues with early Permian fluvial red beds of the Broumov Formation with intercalated volcanic rock (both maphic and felsic) and grey lacustrine horizons. Lacustrine strata provided rich faunas and macrofloras (Pešek et al. 2001, Opluštil et al. 2017). The remaining Permian lithostratigraphic units, the Trutnov and Bohuslavice formations, were deposited after the hiatus associated with the Saale tectonic event. Neither yielded any fossil plants (Opluštil et al. 2017).

\section{Material and methods}

During 2012-2015 a group of Czech palaeobotanists and palynologists created the database named the MafDat (a special software) in the West Bohemian Museum in Pilsen, and included all available palynological records and all occurrences of Carboniferous/early Permian plants from the Czech part of the Intra-Sudetic Basin (Opluštil et al. 2017). The bulk of palynological data presented herein is represented by 62 short unpublished manuscripts (palynological reports to boreholes) of Valterová (1965, 1967a-i, 1968a-d, 1969a-d, 1970, 1972, 1974, 1976, 1977a, b, 1978, 1979a-h, 1980a-e, 1981a-c, 1982a-e, 1984a, b, and 1986a-n) supplemented by the research of the first author (in Libertín et al. 2009). The samples were macerated at Geoindustria Prague, an exploration company during last few decades (1965-1986). Nearly all palynological samples were mostly taken from coal seams and associated carbonaceous mudstones. Dispersed miospores and pollen were recovered by dissolving of rocks in nitric acid for 24-48 hours and $\mathrm{KOH}$ for 1-2 hours and washed by water several times. Miospores and pollen were classified according to the system of dispersed fossil spores suggested by Potonié \& Kremp $(1954,1955)$, Dettmann (1963) and Smith \& Butterworth (1967) by Valterová. Species in samples without specification of their percentage, or number of specimens were recorded in the database as either present or absent. Where quantitative analyses of miospores and pollen from coal seams were made by Valterová, we counted the number of miospores/ pollen as a simple average mean for each sample, i.e. one percent was one hundredth of total summary of all miospore and pollen specimens per sample.

The stratigraphic resolution is to the scale of individual coal seams. In case of non-coal-bearing strata, stratigraphic resolution is at the level of individual lacustrine horizon. Although macroflora was recovered from red beds (Opluštil et al. 2017), no miospores are known from this type of lithology.

Palynological data stored in the MafDat database have been consequently exported to two Excel spreadsheets tables. In the first one (electronic supplement 1) palynospecies are plotted against the stratigraphic column with resolution of individual fossiliferous horizons, 


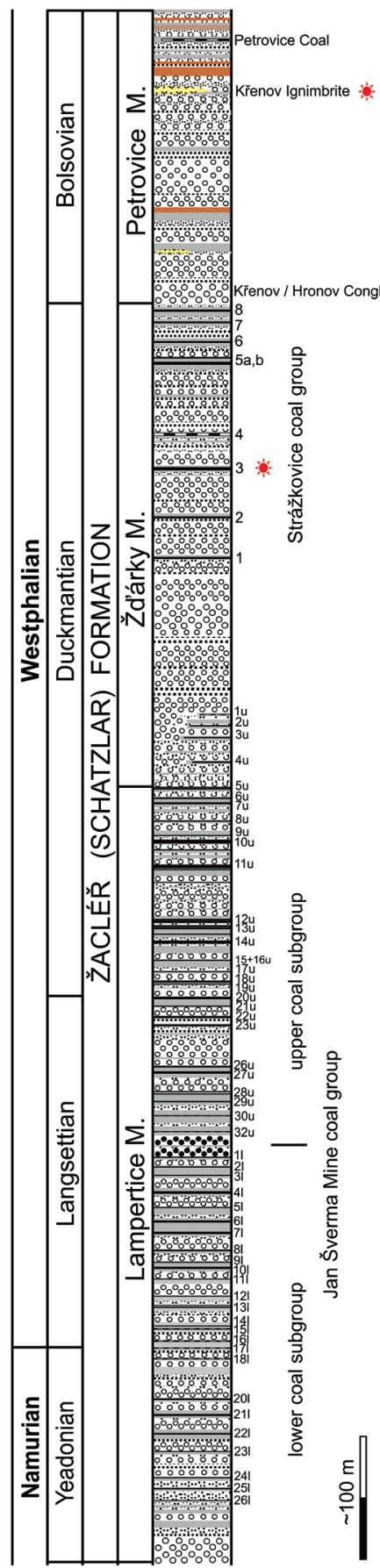

$\because \%$ Conglomerate

20:80:
conglomerate between lower and upper $\therefore \rightarrow$ Breccia

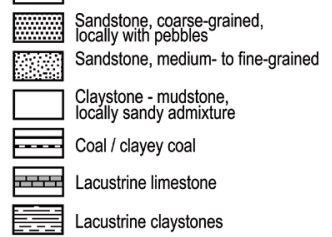

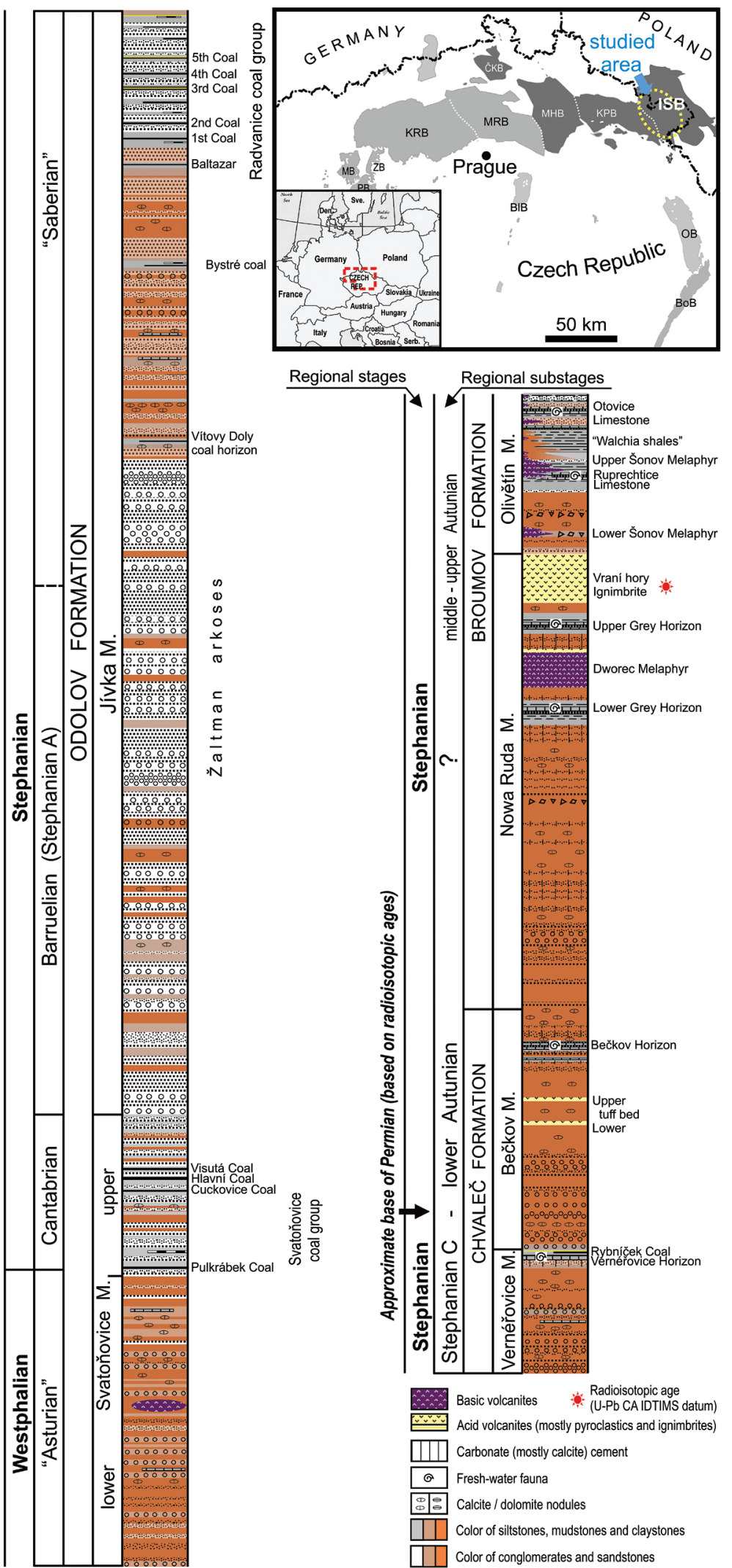

Figure 1. Lithostratigraphic subdivision of the Czech part of the Intra-Sudetic Basin. Post "Autunian" units are unfossiliferous and omited in this scheme. After Opluštil et al. (2016a). Abbreviation: M. - member. 


\begin{tabular}{|c|c|c|c|c|c|c|c|c|}
\hline \multirow[t]{2}{*}{ Genus } & \multirow{2}{*}{$\begin{array}{c}\text { Formation } \\
\text { Member }\end{array}$} & \multicolumn{3}{|c|}{ ŽACLÉŘ } & \multicolumn{2}{|c|}{ ODOLOV } & \multirow{2}{*}{$\begin{array}{l}\text { CHVALEČ } \\
\text { Vernéřovice }\end{array}$} & \multirow{2}{*}{$\begin{array}{l}\text { BROUMOV } \\
\text { Olivětín }\end{array}$} \\
\hline & & Lamp. & Prk. Důl-Žd’árky & Petr. & Svat. & Jívka & & \\
\hline \multicolumn{9}{|c|}{ Spinosporites } \\
\hline \multicolumn{9}{|c|}{ Cadiospora } \\
\hline \multicolumn{9}{|c|}{ Potonieisporites } \\
\hline \multicolumn{9}{|c|}{ Angulisporites } \\
\hline \multicolumn{9}{|c|}{ Aumancisporites } \\
\hline \multicolumn{9}{|c|}{ Lundbladispora } \\
\hline \multicolumn{9}{|c|}{ Lueckisporites } \\
\hline \multicolumn{9}{|c|}{ Latensina } \\
\hline \multicolumn{9}{|c|}{ Gillespieisporites } \\
\hline \multicolumn{9}{|c|}{ Speciososporites } \\
\hline \multicolumn{9}{|c|}{ Kosankeisporites } \\
\hline \multicolumn{9}{|c|}{ Variouxisporites } \\
\hline \multicolumn{9}{|c|}{ Torispora } \\
\hline \multicolumn{9}{|c|}{ Kuhlensisporites } \\
\hline \multicolumn{9}{|c|}{ Tripartites } \\
\hline \multicolumn{9}{|c|}{ Stellisporites } \\
\hline \multicolumn{9}{|c|}{ Reinschospora } \\
\hline \multicolumn{9}{|c|}{ Stenozonotriletes } \\
\hline \multicolumn{9}{|c|}{ Camptotriletes } \\
\hline \multicolumn{9}{|c|}{ Cingulizonates } \\
\hline \multicolumn{9}{|c|}{ Anaplanisporites } \\
\hline \multicolumn{9}{|c|}{ Foveosporites } \\
\hline \multicolumn{9}{|c|}{ Radiizonates } \\
\hline Waltzisp & & & & & & & & \\
\hline
\end{tabular}

Figure 2. Gradual appearance of selected miospore and pollen genera through the profile of the Czech part of the Intra-Sudetic Basin. Abbreviations: Lamp. Lampertice Member; Prk. DůlŽd'árky - Prkenný Důl-Žd'árky Member; Petr. - Petrovice Member; Svat. - Svatoňovice Member. usually cyclothems and lacustrine strata. This resolution is identical with that used by Opluštil et al. (2017) for a similar study on macroflora in the same part of the basin. The purpose is obvious - to allow palynological data to be directly comparable with similar macrofloral data (Opluštil et al. 2017) by individual stratigraphic intervals. Similar to the macrofloral analysis, the presence of each palynological taxon is expressed as " 1 " whereas its absence as " 0 ". Empty fields between the first and last occurrences of any the taxon were subsequently filled by 1 , based on assumption of continuous presence of the species in the study area, although it was not actually found at that or those levels (electronic supplement 1). To clearly distinguish between stratigraphic intervals where the taxon was found from those where its presence is only an interpretation, we marked the fields with the proved occurrence by grey colour while the fields with interpreted occurrences are white. This through-range approach to determine species richness is commonly applied in similar biostratigraphic studies and allows more reliable interpretation of biodiversities (e.g. Cleal 2005, Gastaldo et al. 2009, Cleal et al. 2012, Opluštil et al. 2017). Although such "smoothing" of the data may cause some detail in diversity change to be lost, we believe that absence of some taxa in particular level (e.g. coal horizon) is reflecting local-scale habitat heterogeneity, rather than the change in landscape-scale vegetation. For a further discussion on the legitimacy of using range-through data for such studies, we recommend paper of Gastaldo et al. (2009).

The number of species in each stratigraphic horizon was counted for larger taxonomical groups (usually families or orders and higher) based on botanical affinity to parent plants, if known. The table was consequently used for the construction of diversity curves of palynological taxa by botanical groups as well as the curve of overall diversity of palynological taxa throughout the studied interval in a similar resolution as used for macroflora (Opluštil et al. 2017).

The second table (electronic supplement 2) provides percentage values of individual genera plotted against stratigraphic column of the studied basin interval with the same resolution as in the electronic supplement 1. However, in this case, the fields between the first and last occurrence of the genus, where no data were available, remained empty. Data in the table has been used for the construction of graphs of percentage distribution of miospore and pollen genera throughout the studied 
stratigraphic interval and, in turn, for consideration of original vegetation patterns. Fig. 2 shows gradual appearance of selected miospore and pollen genera through the profile of the basin and Fig. 3 the same for miospore and pollen species.

West European regional chronostratigraphic stages and substages correlated with macrofloral biozones (Wagner 1984, Wagner \& Álvarez-Vázquez 2010, Cleal 2018) are used throughout the paper instead the international chronostratigraphic stages defined dominantly on marine fauna in carbonate successions of east European Platform (Schneider et al. 2020). The regional ("Heerlen") stages are well defined in the Czech part of the Intra-Sudetic Basin (Opluštil et al. 2017) and radioisotopically constrained (Opluštil et al. 2016a). Their correlation to global stages is not a matter of this study, and therefore we refer readers to available summarising papers on this topic (e.g. Davydov et al. 2010, Opluštil et al. 2016b, Schneider et al. 2020).

\section{Results}

Palynological data summarised in electronic supplement 1 were obtained from 37 boreholes, several coal mines and exposures in the Czech part of the Intra-Sudetic Basin and represent 59 different stratigraphic levels. Overall diversity of palynoflora in individual stratigraphic levels varies between 8 and 158 species throughout the $21 \mathrm{Ma}$ fossiliferous interval comprising Bashkirian to Asselian strata (electronic supplement; Fig. 4). Generally, high miospore and pollen diversity is typical for coalbearing intervals with high preservation potential. In contrast, palynological record of red beds is so far absent except grey lacustrine horizons occasionally interrupting the monotonous fluvial red beds (Fig. 1). The only palynological data from these successions were obtained by interpolation between bounding fossiliferous coal-bearing or lacustrine horizons below and above.
Figure 3. Gradual appearance of selected miospore and pollen species through the profile of the Czech part of the Intra-Sudetic Basin. Abbreviations: Lamp. Lampertice Member; Prk. DůlŽd'árky - Prkenný Důl-Žd'árky Member; Petr. - Petrovice Member; Svat. - Svatoňovice Member.

\begin{tabular}{|c|c|c|c|c|c|c|c|c|}
\hline \multirow[t]{2}{*}{ Species } & \multirow{2}{*}{$\begin{array}{c}\text { Formation } \\
\text { Member }\end{array}$} & \multicolumn{3}{|c|}{ ŽACLÉŘ } & \multicolumn{2}{|c|}{ ODOLOV } & \multirow{2}{*}{$\begin{array}{l}\text { CHVALEČ } \\
\text { Vernéřovice }\end{array}$} & \multirow{2}{*}{$\begin{array}{c}\text { BROUMOV } \\
\text { Olivětín }\end{array}$} \\
\hline & & Lamp. & Prk. Důl-Žd'árky & Petr. & Svat. & Jívka & & \\
\hline \multicolumn{9}{|c|}{ Spinosporites spinosus } \\
\hline \multicolumn{9}{|c|}{ Apiculatisporites baccatus } \\
\hline \multicolumn{9}{|c|}{ Potonieisporites novicus } \\
\hline \multicolumn{9}{|c|}{ Endosporites globiformis } \\
\hline \multicolumn{9}{|c|}{ Kosankeisporites elegans } \\
\hline \multicolumn{9}{|c|}{ Punctatosporites speciosus } \\
\hline \multicolumn{9}{|c|}{ Thymospora thiessenii } \\
\hline \multicolumn{9}{|c|}{ Lundbladispora gigantea } \\
\hline \multicolumn{9}{|c|}{ Latensina triletus } \\
\hline \multicolumn{9}{|c|}{ Disaccites } \\
\hline \multicolumn{9}{|c|}{ Punctatosporites speciosus } \\
\hline \multicolumn{9}{|c|}{ Wilsonites delicatus } \\
\hline \multicolumn{9}{|c|}{ Speciososporites laevigatus } \\
\hline \multicolumn{9}{|c|}{ Punctatosporites pygmaeus } \\
\hline \multicolumn{9}{|c|}{ Wilsonites kosankei } \\
\hline \multicolumn{9}{|c|}{ Torispora undulata } \\
\hline \multicolumn{9}{|c|}{ Cristatisporites saarensis } \\
\hline \multicolumn{9}{|c|}{ Tripartites } \\
\hline \multicolumn{9}{|c|}{ Cingulizonates tuberosus } \\
\hline \multicolumn{9}{|c|}{ Apiculatisporites abditus } \\
\hline \multicolumn{9}{|c|}{ Alatisporites hexalatus } \\
\hline Reinscho & a magnifica & & & & & & & \\
\hline Savitrisp & s nux & & & & & & & \\
\hline Lophozon & letes & & & & & & & \\
\hline Grumosis & & & & & & & & \\
\hline Dictyotril & bireticulatus & & & & & & & \\
\hline Bellispor & itidus & & & & & & & \\
\hline Cingulizo & es radiatus & & & & & & & \\
\hline Radiizonc & & & & & & & & \\
\hline Murospor & ulcata & & & & & & & \\
\hline Apiculati: & ites aculeatus & & & & & & & \\
\hline Anaplani: & ites globosus & & & & & & & \\
\hline Alatispor & pustulatus & & & & & & & \\
\hline Acanthot & es echinatus & & & & & & & \\
\hline
\end{tabular}


Palynoflora diversity + pteridosperms

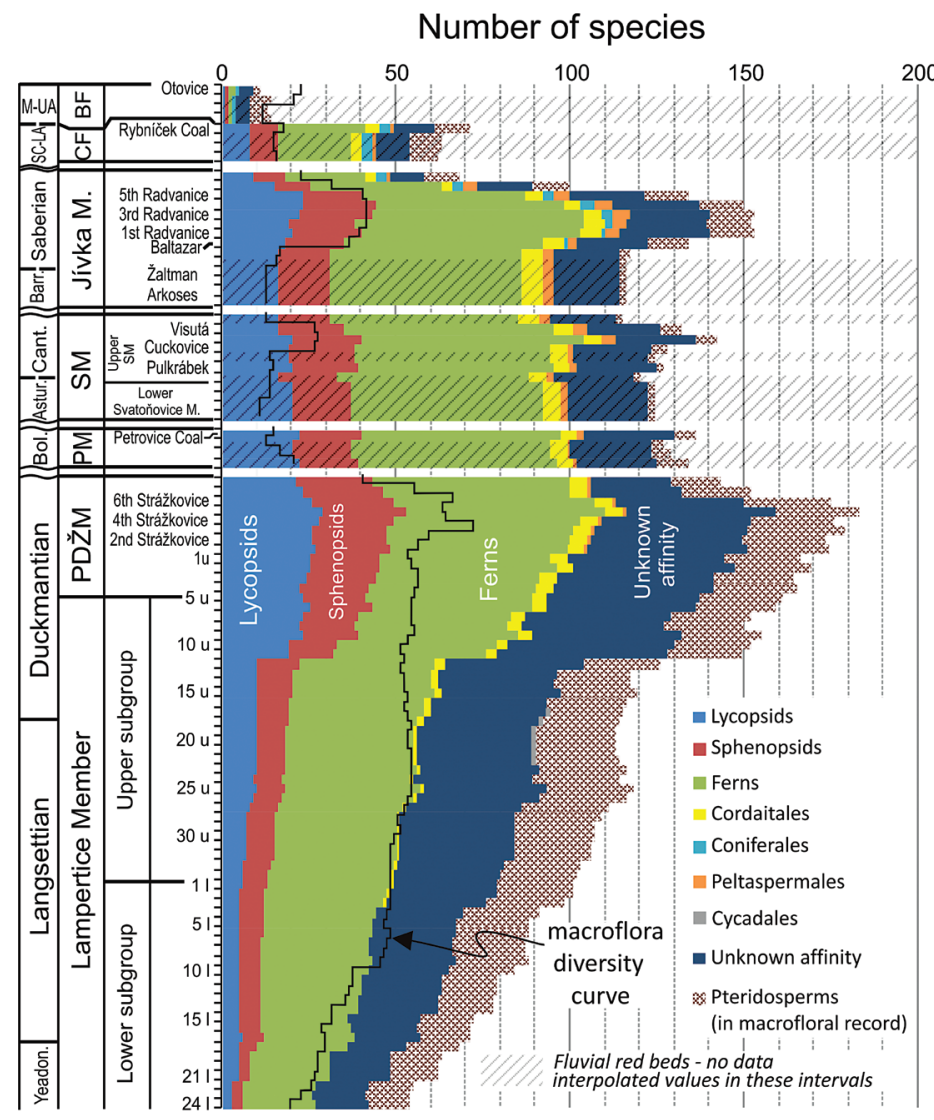

Macroflora diversity

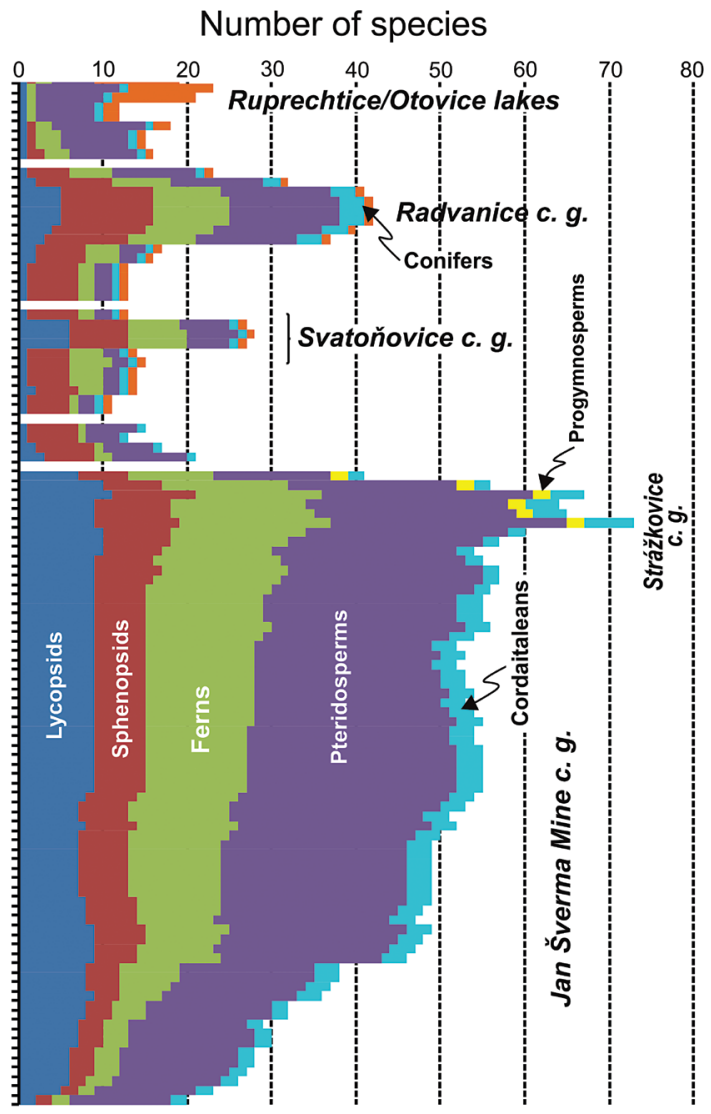

Figure 4. Comparison of diversities of miospores and macroflora in the Czech part of the Intra-Sudetic Basin. Macrofloral data adapted from Opluštil et al. 2017. Abbreviations: Yeadon. - Yeadonian; PDŽM - Prkenný Důl-Žd'árky Member; PM - Petrovice Member; SM - Svatoňovice Member; M. - member; CF - Chvaleč Formation; BF - Broumov Formation; Bol. - Bolsovian; Astur. - Asturian; Cant. - Cantabrian; Barr. - Barruelian; SC-LA - Stephanian C-lower Autunian; M-UA - middle-upper Autunian; c. g. - coal group.

There is a gradual increase in the number of species from about 41 to 48 at the base of the Lampertice Member (= base of the studied succession), up to 103 species at the $12^{\text {th }}$ coal of the upper subgroup (Fig. 4). Between the $12^{\text {th }}$ and $11^{\text {th }}$ coal of the upper subgroup 24 new taxa, mostly lycopsid and sphenopsid miospores, appear and the assemblage of this interval reaches 127 species (electronic supplement 1, Figs 4, 5). Above this level the overall diversity increases up to its maximum of 158 species at the $5^{\text {th }}$ Strážkovice Coal in the upper part of the Prkenný Důl-Žd'árky Member (upper Duckmantian). It is followed by drop to 128 species recorded between the $5^{\text {th }}$ and the $8^{\text {th }}$ Strážkovice coals at the top of the Prkenný Důl-Žd'árky Member.

Following upwards, there is a thick fossil-barren interval up to base of the Svatoňovice coal group (Cantabrian) where only interpolated values for palynoflora diversity are available, except for the Petrovice Coal in the uppermost part of the Petrovice Member (Bolsovian).
Interpolated values in red beds, however, surprisingly suggest presence of 121 palynospecies (Fig. 4), whereas in the Petrovice Coal and Svatonovice coal group the diversity increases to $124-135$ species. At the top of the coal group another drop of diversity is observed and $\sim 113$ species (interpolated values) are counted. These values are constant throughout the Barruelian to the lower Saberian red beds of the Jívka Member. The Radvanice coal group (Saberian) in the upper part of the Jívka member marks the second maximum in diversity (134-139 species). Following upwards, the diversity drastically decreases to approximately 57 species at top of this member due to unfavourable conditions for preservation (electronic supplement 1, Fig. 4). These low diversity values persist also in the Vernéřovice Member of the Chvaleč Formation (Stephanian C-lower Autunian). The Asselian strata above are poorly fossiliferous except for a few lacustrine horizons in the in the Olivětín Member, which provided about $8-9$ species - the lowest values of all. 
Generally, dispersed miospore and pollen assemblages from individual samples are not very rich in the number of specimens. Locally, however, palynological assemblages from some members are richer (Lampertice, Prkenný Důl-Ždárky and Jívka) than from others (Petrovice, Vernéřovice and Olivětín). Dispersed miospore and pollen assemblages from the Czech part of the Intra-Sudetic Basin can be divided into stratigraphically long-ranging of low stratigraphic value and stratigraphically important taxa. Long-ranging taxa (quantitatively variable) included genera Calamospora Schopf et al., Leiotriletes (Naumova) Potonié \& Kremp, Granulatisporites (Ibrahim) Potonié \& Kremp, Punctatisporites (Ibrahim) Potonié \& Kremp, Apiculatisporites (Ibrahim) Potonié \& Kremp, Florinites Schopf et al., Laevigatosporites (Ibrahim) Potonié \& Kremp, Latosporites Potonié \& Kremp, Lophotriletes (Naumova) Potonié \& Kremp, Lycospora (Schopf et al.) Potonié \& Kremp, Raistrickia (Schopf et al.) Potonié
\& Kremp, Savitrisporites Bharadwaj and Triquitrites (Wilson \& Coe) Potonié \& Kremp. Most of these genera are also relatively common; sometimes even abundant (Lycospora, Calamospora and Laevigatosporites).

Genera Waltzispora Staplin, Radiizonates Staplin \& Jansonius, Murospora Somers, Camptotriletes (Naumova) Potonié \& Kremp, Anaplanisporites Jansonius, Reinschospora Schopf et al., Stellisporites Alpern, Tripartites (Schemel) Potonié \& Kremp, Gillespieisporites Clendening, Angulisporites Bharadwaj, Lueckisporites (Potonié \& Klaus) Jansonius, Latensina Alpern, Cadiospora (Kosanke) Turner and Spinosporites Alpern are the most stratigraphically important taxa. Palaeoecologically important taxa included Lycospora, Densosporites (Berry) Butterworth et al., Florinites, smallest monolete species of genera Laevigatosporites, Latosporites, Speciososporites Potonié \& Kremp, Punctatosporites Ibrahim, Thymospora Wilson \& Venkatachala and Torispora Balme.

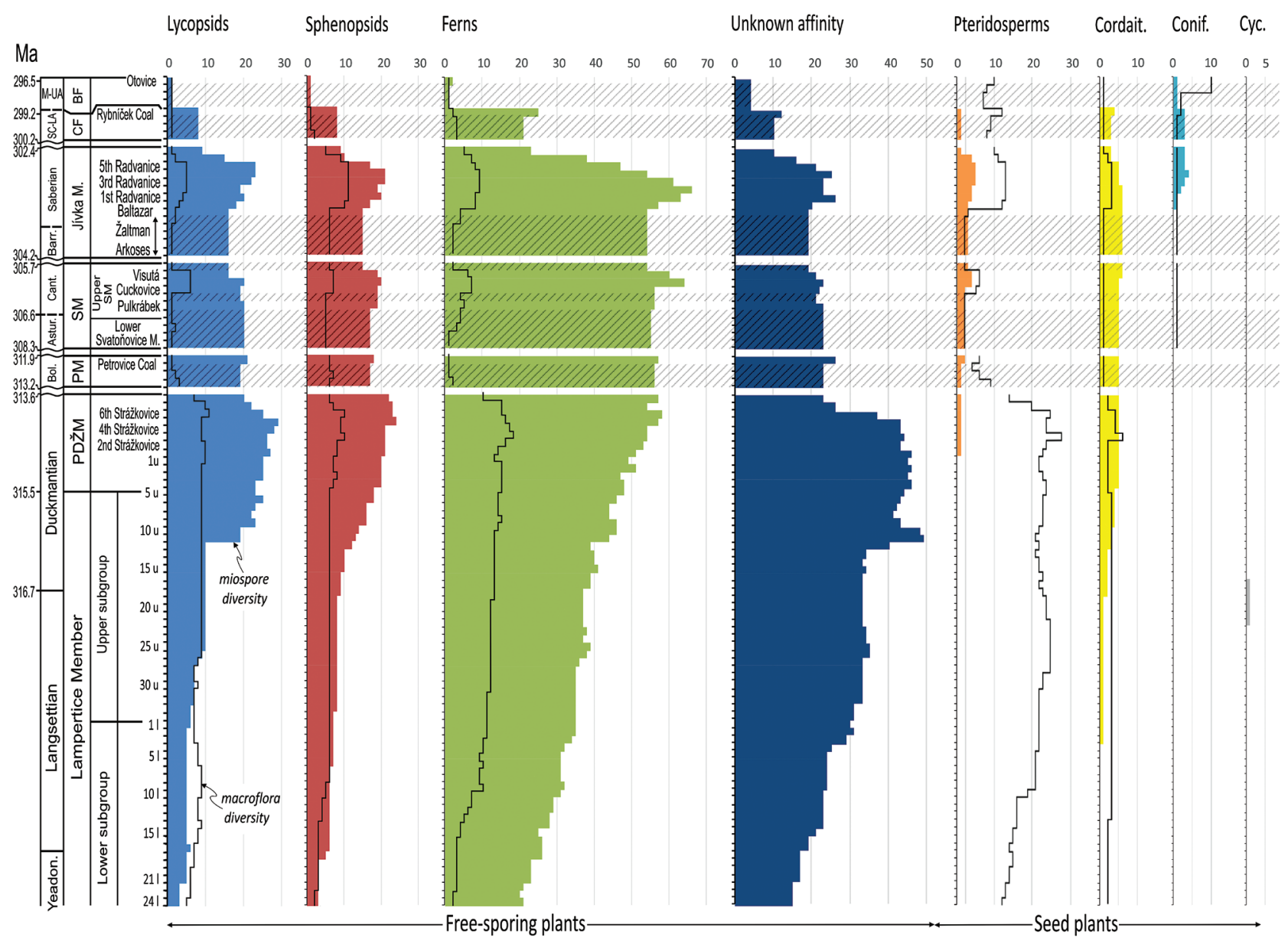

Figure 5. Miospore diversity of major plant groups and comparison with diversity of the same groups in macrofloral record (Opluštil et al. 2017) in the Czech part of the Intra-Sudetic Basin. Abbreviations: Yeadon. - Yeadonian; PDŽM - Prkenný Důl-Žd'árky Member; PM - Petrovice Member; SM Svatoňovice Member; M. - member; CF - Chvaleč Formation; BF - Broumov Formation; Bol. - Bolsovian; Astur. - Asturian; Cant. - Cantabrian; Barr. - Barruelian; SC-LA - Stephanian C-lower Autunian; M-UA - middle-upper Autunian; Cordait. - Cordaitales; Coniferales; Cyc. - Cycadales. 


\section{Palynology of the Czech part of the Intra-Sudetic Basin}

\section{Lampertice Member}

The Lampertice Member stratigraphically covers the interval from the late Namurian (Yeadonian), the whole Langsettian and the early Duckmantian. Dispersed miospore and pollen assemblage consists of 177 species belonging to 56 genera and is the richest (together with that from the Prkenný Důl-Žd'árky Member) of all members. Thirty-eight species are restricted to this interval (Tab. 1). The percentage of some genera increased from the bottom to the top of the member, e.g. Densosporites (max. 30\% at the $10^{\text {th }}$ upper coal seam of the Lampertice Member), Cirratriradites Wilson \& Coe (from the $11^{\text {th }}$ upper coal seam of the Lampertice Member), Laevigatosporites and Latosporites (bigger than $35 \mu \mathrm{m}$ ), Ahrensisporites Potonié \& Kremp, Apiculatisporites and Florinites. The genera Converrucosisporites Potonié \& Kremp, Lophotriletes, Granulatisporites, Leiotriletes, Triquitrites, Dictyotriletes (Naumova) Smith \& Butterworth, Pustulatisporites Potonié \& Kremp and Savitrisporites are the most abundant at this level (electronic supplement 2). It is inter- esting to note that the first appearance of the genus Endosporites Wilson \& Coe within $7^{\text {th }}$ upper coal seam is simultaneously its highest local percentage $(21 \%)$ in the whole basin providing the evidence on local concentration of sub-arborescent lycopsids of the Polysporia type. Kalibová (in Tásler et al. 1979) mentioned the occurrence of only seven megaspore taxa including the species Lagenoisporites rugosus (Loose) Potonié \& Kremp, Cystosporites giganteus (Zerndt) Schopf, Tuberculatisporites mamillarius (Bartlett) Potonié \& Kremp, Triangulatisporites triangulatus (Zerndt) Potonié \& Kremp, Bentzisporites tricollinus (Zerndt) Potonié \& Kremp, Spencerisporites gracilis (Zerndt) Winslow and Pseudovalvisisporites spp.

\section{Prkenný Důl-Žd'árky Member}

The Prkenný Důl-Žd'árky Member stratigraphically belongs to the later part of Duckmantian. Its miospore and pollen assemblage is the richest of all members (together with that from the Lampertice Member) with 177 species belonging to 56 genera. The most abundant genera are Densosporites (16\% on average), Lycospora (15\% on average) and Savitrisporites (6\% on average). Twenty-two

Table 1. The list of dispersed miospores and pollen from the Czech part of the Intra-Sudetic Basin that occur only in one member.

\begin{tabular}{|c|c|c|}
\hline Formation & Member & Miospore and pollen species \\
\hline Chvaleč & Vernéřovice & $\begin{array}{l}\text { Apiculatisporites baccatus, A. baccatus f. trebechovensis, Florinites piérartii, Punctatisporites provectus, } \\
\text { Spinosporites spinosus, Thymospora verrucosa }\end{array}$ \\
\hline \multirow[t]{2}{*}{ Odolov } & Jívka & $\begin{array}{l}\text { Anapiculatisporites conatus, Apiculatisporites latigranifer, Aumancisporites striatus, Cadiospora magna f. } \\
\text { maior, C. magna f. minor, C. magna f. plicata, C. sphaera, Crassispora ovalis, C. plicata, C. pergranulus, } \\
\text { Disaccites spp., Endosporites grandisaccus, Gillespieisporites discoideus, G. spinosus, Guthoerlisporites } \\
\text { magnificus, Illinites unicus, Latensina triletus, Lundbladispora gigantea, Lueckisporites spp., Punctatosporites } \\
\text { bechlinensis, P. oculus, P. speciosus, Raistrickia aculeolata, Speciososporites plicatus, Thymospora thiessenii, } \\
\text { Verrucosisporites donarii, V. grandiverrucosus, V. verrucosus, Wilsonites vesicatus }\end{array}$ \\
\hline & Svatoňovice & $\begin{array}{l}\text { Cirratriradites annulatus, Lycospora micrograna, Torispora granulata, T. undulata, Triquitrites pulvinatus, } \\
\text { Wilsonites kosankei }\end{array}$ \\
\hline \multirow[b]{3}{*}{ Žacléř } & Petrovice & Cristatisporites saarensis \\
\hline & $\begin{array}{l}\text { Prkenný } \\
\text { Dủl-Ždárky }\end{array}$ & $\begin{array}{l}\text { Acanthotriletes triquetrus, Alatisporites hexalatus, Apiculatisporites abditus, Cingulizonates tuberosus, } \\
\text { Cirratriradites flabelliformis, Convolutispora jugosa, Cristatisporites indignabundus, Dictyotriletes falsus, } \\
\text { Florinites antiquus, Kuhlensisporites spp., Lycospora triangulata, Reinschospora magnifica, Stenozonotriletes } \\
\text { lycosporoides, Tripartites spp., Vestispora magna, V. laevigata }\end{array}$ \\
\hline & Lampertice & $\begin{array}{l}\text { Acanthotriletes acerosus, A. falcatus, A. echinatus, A. microspinosus, Alatisporites pustulatus, A. trialatus, } \\
\text { Anapiculatisporites minor, Anaplanisporites globulus, Apiculatisporites aculeatus, Camptotriletes juglandilis, } \\
\text { Calamospora perrugosa, Cingulizonates loricatus, Cirratriradites rarus, Converrucosisporites armatus, } \\
\text { Convolutispora varicosa, C. tessellata, Crassispora maculosa, Cyclogranisporites pressoides, Densosporites } \\
\text { lobatus, D. triangularis, Dictyotriletes reticulocingulum, Endosporites magnificus, Foveosporites spp., } \\
\text { Lycospora parva, Microreticulatisporites reticuloides, Murospora sulcata, Punctatisporites aerarius, } \\
\text { Radiizonates spp., Raistrickia carbondalensis, R. crinita, R. microhorrida, Remysporites magnificus, } \\
\text { Reticulatisporites adhaerens, Savitrisporites majus, Simozonotriletes majus, Stenozonotriletes commendatus, } \\
\text { S. reticulatus, Waltzispora spp. }\end{array}$ \\
\hline
\end{tabular}


species are restricted to this interval (Tab. 1). Some taxa make their first appearance here, e.g. Anapiculatisporites spinosus (Kosanke) Potonié \& Kremp, Vestispora laevigata Wilson \& Venkatachala, V. quaesita (Kosanke) Wilson \& Venkatachala, Punctatosporites granifer Potonié \& Kremp, P. punctatus (Kosanke) Alpern \& Doubinger, Torispora securis Balme, Endosporites formosus Kosanke, Cyclogranisporites jelenicensis Kalibová, Kuhlensisporites spp. and Westphalensisporites irregularis Alpern. Interesting is the local abundance of the genus Densosporites in the lower part of the Strážkovice Group of coals is notable with $63 \%$ on average within $2^{\text {nd }}$ and $3^{\text {rd }}$ Strážkovice Coal Seams. Endosporites, Latosporites (smaller than $35 \mu \mathrm{m}$ ), Vestispora (Wilson $\&$ Hoffmeister) Wilson \& Venkatachala and Leiotriletes are all the most abundant in the $4^{\text {th }}$ Strážkovice Coal Seam with $12,12,13$ and $10 \%$ respectively. The genus Punctatosporites reaches its maximum within the $8^{\text {th }}$ Strážkovice Coal Seam, i.e. the last coal seam of the member. The percentage of the genera Florinites and Savitrisporites increases from the bottom to the top of the member while Densosporites and Vestispora decrease within the same interval. Megaspores of the Prkenný Důl-Žd'árky Member (Kalibová in Tásler et al. 1979) are the same as those from the Lampertice Member except for Triletisporites bohemicus Kalibová that appears for the first time at this level. The most abundant megaspore species is Lagenoisporites rugosus.

\section{Petrovice Member}

The Petrovice Member represents strata of Bolsovian age which are mostly fossil-poor beds with dominant red beds, except the upper part where locally developed thin coal and associated grey mudstones occur. Dispersed miospore and pollen assemblage of this interval yielded a low number of taxa because only 111 species belonging to 43 genera. Cristatisporites saarensis Bharadwaj is recorded only at this level and Thymospora obscura (Kosanke) Wilson \& Venkatachala, Variouxisporites spp. and Vittatina spp. make their first appearance at this level while Knoxisporites polygonalis (Ibrahim) Potonié \& Kremp has its last occurrence. One of stratigraphically most important taxa is Vestispora fenestrata (Kosanke \& Brokaw) Spode in Smith \& Butterworth. No megaspores are described from the Petrovice Member.

\section{Svatoňovice Member}

The Svatoňovice Member stratigraphically corresponds to the Asturian and Cantabrian. Dispersed miospore and pollen assemblage consists of 130 species that belong to 45 genera. Five species are restricted to this interval including Cirratriradites annulatus Kosanke \& Brokaw in
Kosanke, C. flabelliformis Wilson \& Kosanke, Torispora granulata Alpern, T. undulata Dybová \& Jachowicz and Triquitrites pulvinatus Kosanke. Some species make their first occurrence here, e.g. Punctatosporites granulatus Bharadwaj, P. pygmaeus (Imgrund) Potonié \& Kremp, P. rotundus (Bharadwaj) Dybová \& Jachowicz, Verrucosisporites sinensis Imgrund, Wilsonites delicatus (Kosanke) Kosanke and Variouxisporites plicatus Alpern. Only three palynological samples from this member were quantitatively evaluated (Pulkrábek, Main and Visutá coal seams), therefore the data source is limited. The megaspore assemblage is similar to that of the Lampertice Member but four new species appear, Laevigatisporites glabratus (Zerndt) Potonié \& Kremp, Valvisisporites auritus (Zerndt) Potonié \& Kremp, Cystosporites varius (Wicher) Dijkstra and Triletisporites tuberculatus (Zerndt) Potonié \& Kremp that make their first appearance here (Kalibová in Tásler et al. 1979).

\section{Jívka Member}

The Jívka Member stratigraphically ranges Barrualian and Saberian ages. Dispersed miospore and pollen assemblage of the Jívka Member consists of 160 species belonging to 50 genera. Thirty-nine species are restricted to this member (Tab. 1). Some species appear here for the first time, e.g. Apiculatisporites conatus Kalibová, Cadiospora magna Kosanke including forms maior Kalibová, minor Kalibová and plicata Kalibová. It is interesting to note the decrease of Lycospora from the base to the top of the member. The most abundant megaspore species are Valvisisporites auritus and Lagenoisporites levis Zerndt (Kalibová in Tásler et al. 1979). Other megaspore taxa are Calamospora spp., Triangulatisporites triangulatus, Cystosporites giganteus, Spencerisporites gracilis, Laevigatisporites glabratus and Monoletes ellipsoides Ibrahim.

\section{Vernéřovice Member}

The Vernérovice Member is composed of red beds of the late Gzhelian (latest Stephanian to early Autunian) age. Dispersed miospore and pollen assemblages of this member consist of 29 genera with 60 species. No megaspores have been reported from the Vernéřovice Member (Kalibová in Tásler et al. 1979).

\section{Olivětín Member}

The Olivětín Member represents rocks of the late Asselian (middle-late Autunian) age. Only eleven miospore and pollen species were reported from this member: Lycospora spp, Vestispora spp., Punctatosporites granulatus, Lophotriletes mosaicus Potonié \& Kremp, Potoniei- 
Table 2. Affinity of all miospore and pollen genera recorded in the Czech part of the Intra-Sudetic Basin (based on Balme 1995 and Bek 1998, 2017).

\begin{tabular}{|c|c|c|}
\hline \multicolumn{2}{|c|}{ Plant groups/parent genera } & \multirow{2}{*}{$\begin{array}{l}\text { Spores and pollen genera } \\
\text { Cadiospora, Crassispora, Lycospora }\end{array}$} \\
\hline \multirow{3}{*}{ Lycopsids } & Arborescent & \\
\hline & Sub-arborescent & Cristatisporites, Densosporites, Endosporites \\
\hline & Herbaceous & Anapiculatisporites, Cingulizonates, Cirratriradites, Lundbladispora \\
\hline \multirow[b]{2}{*}{ Sphenopsids } & Calamitales & Calamospora \\
\hline & Sphenophyllales & $\begin{array}{l}\text { Dictyotriletes muricatus, Laevigatosporites and Latosporites (more than } 35 \mu \mathrm{m} \text { ), Punctatisporites obesus, } \\
\text { Reticulatasporites, Vestispora }\end{array}$ \\
\hline \multirow{4}{*}{ Ferns } & Marratiales & $\begin{array}{l}\text { Laevigatosporites }(<35 \mu \mathrm{m}), \text { Latosporites }(<35 \mu \mathrm{m}) \text {, Punctatosporites, Speciosporites, Torispora, } \\
\text { Thymospora, Verrucosisporites, Cyclogranisporites, Punctatisporites (except for P. obesus), } \\
\text { Tuberculatosporites }\end{array}$ \\
\hline & Zygopteridales & $\begin{array}{l}\text { Convolutispora, Verrucosisporites, Apiculatasporites, Apiculatisporites, Punctatisporites } \\
\text { (except for P. obesus), Cyclogranisporites }\end{array}$ \\
\hline & Botryopteridales & $\begin{array}{l}\text { Verrucosisporites, Convolutispora, Camptotriletes, Microreticulatisporites, Raistrickia, Lophotriletes, } \\
\text { Granulatisporites, Cyclogranisporites }\end{array}$ \\
\hline & Gleicheniales & Triquitrites, Leiotriletes \\
\hline \multirow{4}{*}{ Gymnosperms } & Cordaitales & Florinites \\
\hline & Coniferales & Lueckisporites, Potonieisporites \\
\hline & Cycadales & Remysporites \\
\hline & Peltaspermales & Vittatina, Wilsonites, Guthoerlisporites \\
\hline Unknown origin & & $\begin{array}{l}\text { Acanthotriletes, Ahrensisporites, Alatisporites, Anaplanisporites, Angulisporites, Bellispores, } \\
\text { Converrucosisporites, Dictyotriletes, Disaccites, Euryzonotriletes, Foveosporites, Gillespieisporites, } \\
\text { Grumosisporites, Illinites, Knoxisporites, Kosankeisporites, Kuhlensisporites, Latensina, } \\
\text { Lophozonotriletes, Mooreisporites, Murospora, Planisporites, Polymorphisporites, Pustulatisporites, } \\
\text { Radiizonates, Reinschospora, Reticulatisporites (except for R. muricatus), Savitrisporites, } \\
\text { Simozonotriletes, Sinuspores, Spinosporites, Stellisporites, Stenozonotriletes, Variouxisporites, } \\
\text { Westphalensisporites }\end{array}$ \\
\hline
\end{tabular}

Table 3. Percentage of miospores and pollen of main plants groups in all members in the Czech part of the Intra-Sudetic Basin. Abbreviations: Lamp. Lampertice Member; Prk. Důl - Prkenný Důl Member; Petr. - Petrovice Member; Svat. - Svatoňovice Member; Vern. - Vernéřovice; Od. - Odolov Formation.

\begin{tabular}{|c|c|c|c|c|c|c|c|c|c|}
\hline Plant group & & Lamp. & Prk. Důl & Petr. & Svat. & Jívka & Vern. & Od. & Generally \\
\hline \multirow{3}{*}{ Lycopsids } & Arborescent & 6 & 5 & 5 & 4 & 7 & 7 & 11 & 6.5 \\
\hline & Sub-arborescent & 8 & 7 & 5 & 4 & 5 & 0 & 0 & 4.1 \\
\hline & Herbaceous & 5 & 5 & 5 & 4 & 2 & 0 & 0 & 3.0 \\
\hline \multirow{2}{*}{ Sphenopsids } & Calamites & 1 & 2 & 3 & 2 & 2 & 3 & 0 & 1.9 \\
\hline & Sphenophylls & 5 & 7 & 5 & 8 & 4 & 4 & 0 & 4.8 \\
\hline Ferns & & 31 & 30 & 40 & 42 & 34 & 49 & 22 & 35.4 \\
\hline Noeggerathiopsids & & 2 & 3 & 5 & 4 & 3 & 7 & 0 & 3.4 \\
\hline Gymnosperms & & 1 & 5 & 3 & 8 & 8 & 10 & 0 & 5.0 \\
\hline Conifers & & 0 & 0 & 0 & 0 & 3 & 3 & 11 & 2.4 \\
\hline Unknown origin & & 41 & 36 & 29 & 24 & 32 & 17 & 56 & 33.5 \\
\hline
\end{tabular}

sporites novicus Bharadwaj, Ahrensisporites angulatus (Kosanke) Dybová \& Jachowicz, Ahrensisporites spp., Converrucosisporites spp., Gillespieisporites spp. and
Kosankeisporites spp. and all records represent only one specimen. No megaspores have been described from the Vernéřovice Member (Kalibová in Tásler et al. 1979). 


\section{Reconstruction of plant assemblages}

It is possible to divide all dispersed miospores and pollen into several groups based on their parent plants. Table 2 shows the affinity (lycopsids, sphenopsids, ferns, gymnosperms including cordaites, conifers, cycadaleans and pteridosperms) of all miospore and pollen genera including a group with unknown producers. The percentage of miospores and pollen of main plant groups within the profile is shown in Tab. 3 .

The percentage of some miospore genera produced by ferns of different groups is divided equally according to the number of groups of their producers. Fifty percent of Convolutispora Hoffmeister et al. is divided between zygopterids and botryopterids and Punctatisporites into marattialeans and zygopterids. Thirtythree percent of Cyclogranisporites Potonié \& Kremp and Verrucosisporites (Ibrahim) Smith \& Butterworth is divided among marattialeans, zygopterids and botryopterids. Monolete laevigate miospores of the Laevigatosporites and Latosporites types are divided based on their diameter that corresponds with their different plant producers. Specimens smaller than $35 \mu \mathrm{m}$ [Laevigatosporites minimus (Wilson \& Coe) Schopf et al. and Latosporites globosus Schemel)] belong to marattialeans (Balme 1995) all others are assigned to sphenophylls (Libertín et al. 2014). Calamospora is interpreted as sphenopsid miospore because other possible Calamospora-producers were not recognised in the basin.

\section{Lycopsid spores}

It is possible to divide lycopsid miospores into three main groups based on different morphological type/habit of their producers; miospores of arborescent [Lycospora, Crassispora (Bharadwaj) Sullivan and Cadiospora], sub-arborescent [Densosporites, Endosporites and Cristatisporites (Potonié \& Kremp) Staplin \& Jansonius] and herbaceous [Cirratriradites, Cingulizonates (Dybová \& Jachowicz) Butterworth et al., Lundbladispora (Balme) Playford) and Anapiculatisporites Potonié \& Kremp] forms (electronic supplement 1, 2; Tab. 3). In the macrofloral record, lycopsid diversity is highest during the Langsettian and Duckmantian, where nine species of lepidodendrids and sigillarians make between 15 and $25 \%$ of the total diversity (Opluštil et al. 2017). It corresponds with the occurrence of Lycospora that makes $30 \%$ on average from all miospores of the Lampertice Member with maximum occurrences of 68 and $92 \%$ in the $26^{\text {th }}$ and $33^{\text {rd }}$ upper coal seams respectively (Fig. 6). Generally, Lycospora is more abundant in older strata of the Lampertice Member than in the Prkenný Důl-Žd'árky $(14 \%)$, Svatoňovice (11\%) and Jívka (10\%) members.
It suggests a distinctive decline of their producers, i.e. arborescent lycopsids of the genera Lepidodendron Sternberg and Lepidophloios Sternberg from the Langsettian to the Cantabrian that is also confirmed by the macrofloral record (Opluštil et al. 2017). Crassispora and Cadiospora genera make their first appearance higher in the Prkenný Důl-Žd'árky Member but are much rarer, especially within the Prkenný Důl-Žd'árky Member. Crassispora produced by sigillarians (Balme 1995) has its maximum occurrence within the Jivka Member (only 3\%) and Cadiospora - produced by sigillarians bearing cones of the Thomasostrobus type (Opluštil et al. 2009) - within the Prkenný Důl-Žd'árky Member (only $2 \%$ ). In the Bolsovian red bed interval of the Petrovice Member, the number of lycopsid species gradually decreases to less than five reaching $\sim 7 \%$ of the total plant diversity and remains at similar values throughout most of the late Moscovian and late Pennsylvanian (Fig. 6). The only exceptions are coal-bearing intervals of the Svatoňovice (Cantabrian) and Radvanice (Saberian) groups, where number of taxa of arborescent lycopsids and their percentage within the entire diversity approaches Langsettian and Duckmantian values (Opluštil et al. 2017). However, as these authors pointed out, in these Stephanian windows of preservation, species composition of lycopsids and their small populations, expressed by general rarity of their compressions, contrast significantly with their richness and composition in Langsettian and Duckmantian macrofloras. In contrast, diversity of lycopsids in the palynological record shows an opposite trend where lowest values are typical of Langsettian to early Duckmantian times. Diversity significantly increases earlier than mid Duckmantian (Fig. 6) and reaches its maximum ( $25 \%$ of all diversity) in the late Duckmantian Strážkovice coal group with subsequent minor drop to $20 \%$ at the top of that coal group. This prominent rise is due to an increase in number of miospore taxa produced by arborescent (lepidodendrids) and sub-arborescent lycopsids. Values between 15 and $20 \%$ persist throughout the most of the late Pennsylvanian. Together with macrofloral record suggests that lepidodendrid lycopsids were part of the wetland ecosystems until the latest Gzhelian (Opluštil et al. 2017). In palynological data, however, Lycospora occurs even in strata of Asselian age (electronic supplement 1, Fig. 7) and thus may indicate survival of their producers until early Permian times. Palynological record also confirms the presence of sub-arborescent and herbaceous lycopsids, the remains of which in compression record are exceptional (Bek et al. 2009, 2015; Opluštil et al. 2017). Miospores of subarborescent lycopsids belong to rare spore types with only $6 \%$ on average from the Lampertice to the Jívka members and maximum $18 \%$ within the Prkenný Důl-Žd'árky Member. Miospores produced by herbaceous lycopsids 


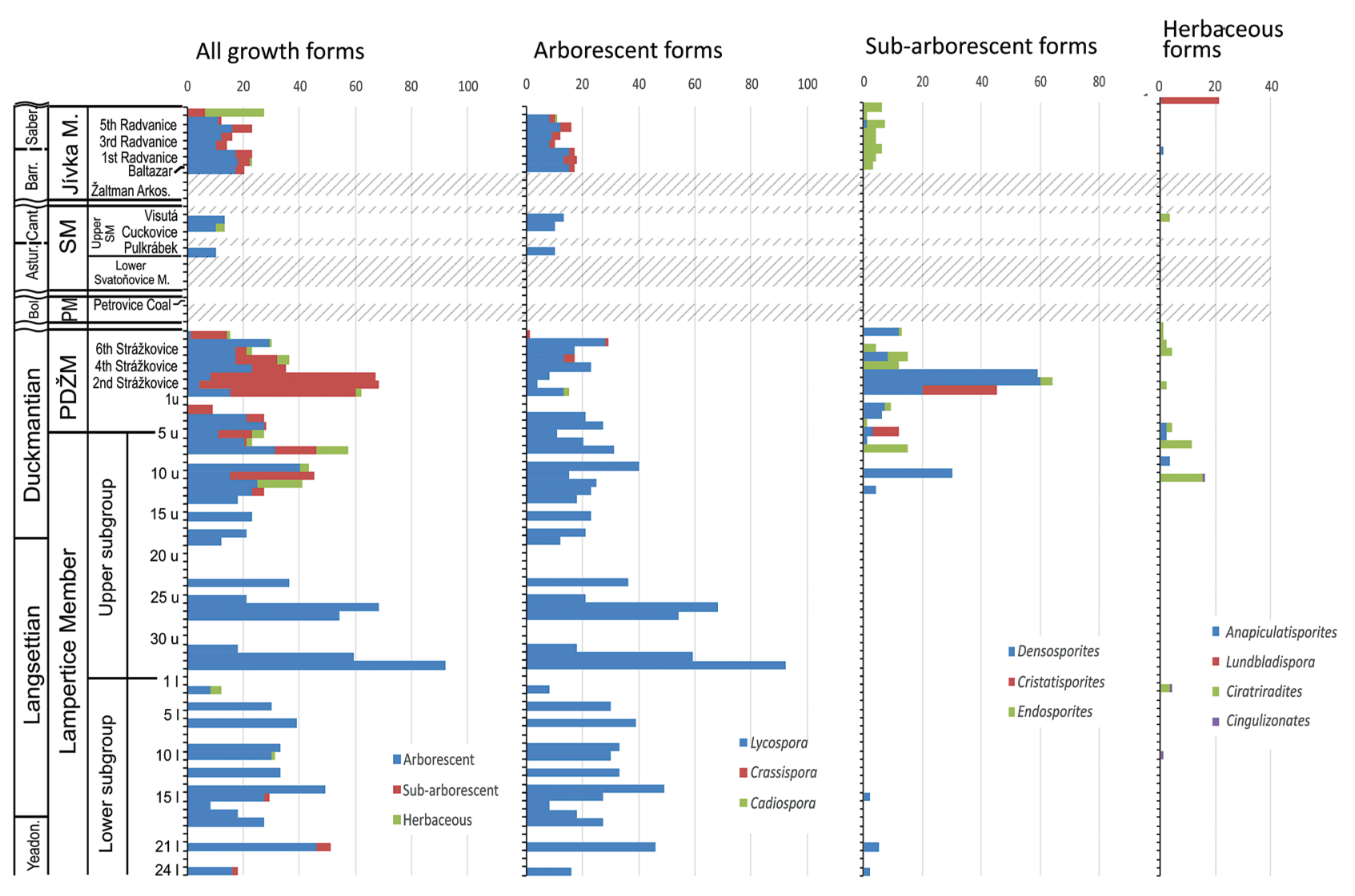

Figure 6. Percentage abundancy of lycopsid miospores in the Intra-Sudetic Basin. Abbreviations: Yeadon. - Yeadonian; PDŽM - Prkenný Důl-Žd'árky Member; PM - Petrovice Member; SM - Svatoňovice Member; M. - member; CF - Chvaleč Formation; BF - Broumov Formation; Bol. Bolsovian; Astur. - Asturian; Cant. - Cantabrian; Barr. - Barruelian; Saber. - Saberian.

are even rarer with $1.75 \%$ on average from the Lampertice to the Jívka members. A slightly increasing occurrence is recorded within the Jívka Member (3\%). Miospores of lycopsids make up almost $30 \%$ on average from the Lampertice to the Jivka members with the highest occurrence within the Prkenný Důl-Žd'árky members (36\%).

The general pattern of lycopsid miospores is their decrease from the Lampertice (34\% on average), Prkenný Důl-Žd'árky ( $14 \%$ on average), Svatoňovice ( $11 \%$ on average) to the Jívka Member (10\% on average). Megaspores assemblages of the Lampertice and Prkenný DůlŽd'árky members are very similar (Kalibová in Tásler et al. 1979). The most abundant are megaspores produced by flemingitacean arborescent forms that correspond with the miospore record. Seed-like megaspores of the Cystosporites type produced by arborescent lycopsids of the Lepidocarpon and Achlamydocarpon types occurred from the Lampertice to the Jívka members, but their "male counterparts", i.e. miospores of the Cappasporites type have never been described in the basin. The occurrence of megaspores of other groups of sigillarians is the same (Crassispora miospores). Miospores produced by sub-arborescent lycopsids of the Polysporia type occur from the upper part of the Lampertice Member but their megaspores are recoded in the Prkenný Důl-Žd'árky Member for the first time. It is interesting to note that megaspores of other sub-arborescent lycopsids of the Omphalophloios type have never been recorded, although its miospores of the Densosporites/Cristatisporites types are recorded in the entire profile and reach local maximum (up to 65\%) in the Prkenný Důl-Žd'árky Member. Although sub-arborescent lycopsids of the Spencerites type are not recorded in the basin, their spores (sometimes referred to megaspores or isospores) of the Spencerisporites type are known from the Lampertice to the Jívka members. Megaspores of the Triangulatisporites and Bentzisporites types produced by herbaceous lycopsids of the Selaginella type occur from the Lampertice to the Jívka members that correspond with ranges of their miospores of the Cirratriradites and Lundbladispora types.

\section{Sphenopsid spores}

Miospores of sphenopsids are divided into two groups (electronic supplement 1; Figs 8, 9); calamitean (Calamo- 

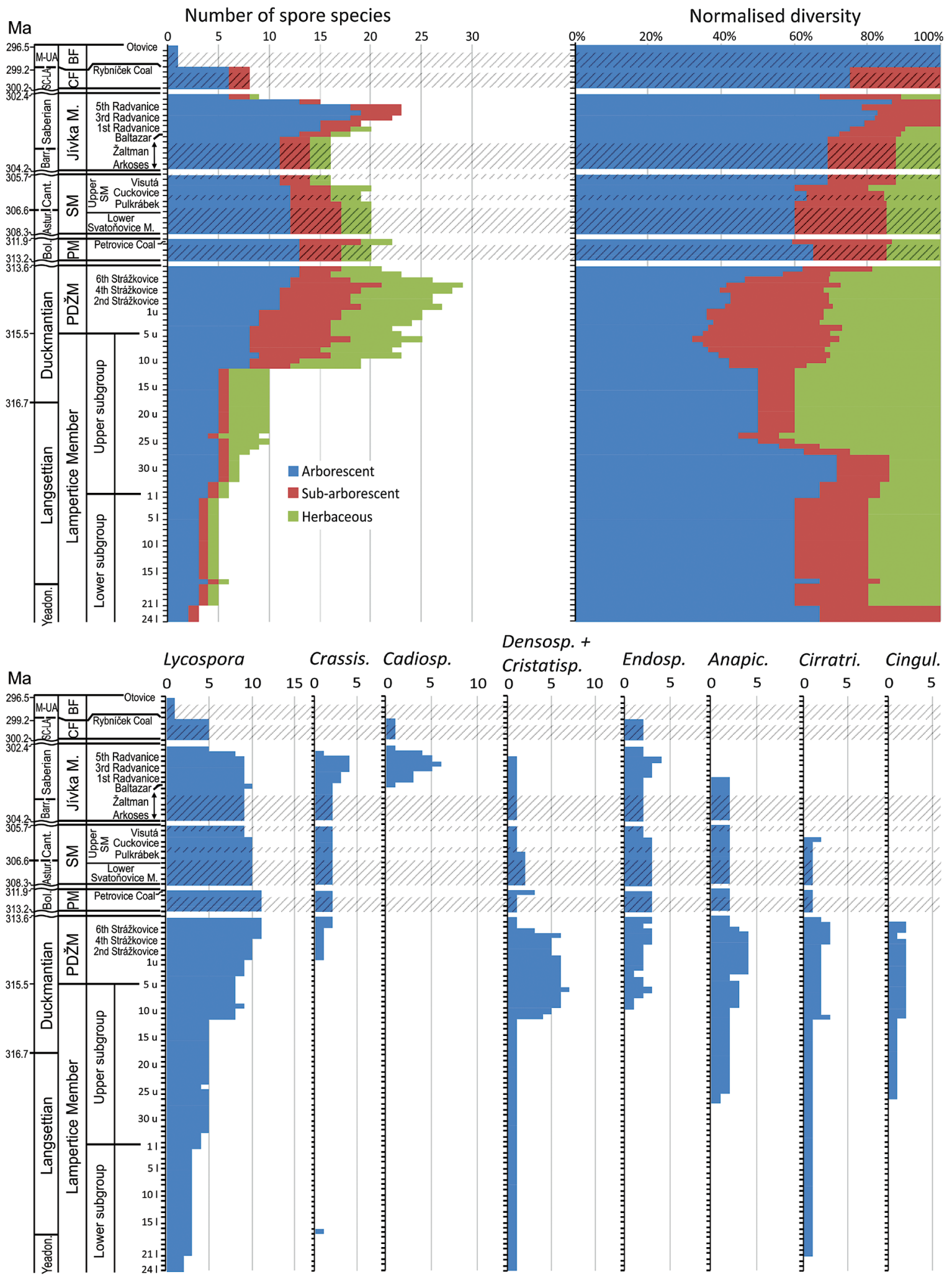

Figure 7. Species diversity of lycopsid miospores in the Czech part of the Intra-Sudetic Basin. Abbreviations: Yeadon. - Yeadonian; PDŽM - Prkenný Důl-Žd'árky Member; PM - Petrovice Member; SM - Svatoňovice Member; M. - member; CF - Chvaleč Formation; BF - Broumov Formation; Bol. - Bolsovian; Astur. - Asturian; Cant. - Cantabrian; Barr. - Barruelian; Saber. - Saberian; SC-LA - Stephanian C-lower Autunian; M-UA - middle-upper Autunian; Crassis. - Crassispora; Cadiosp. - Cadiospora; Densosp. - Densosporites; Cristatisp. - Cristatisporites; Endosp. Endosporites; Anapic. - Anapiculatisporites; Cirratri. - Cirratriradites; Cingul. - Cingulizonates. 


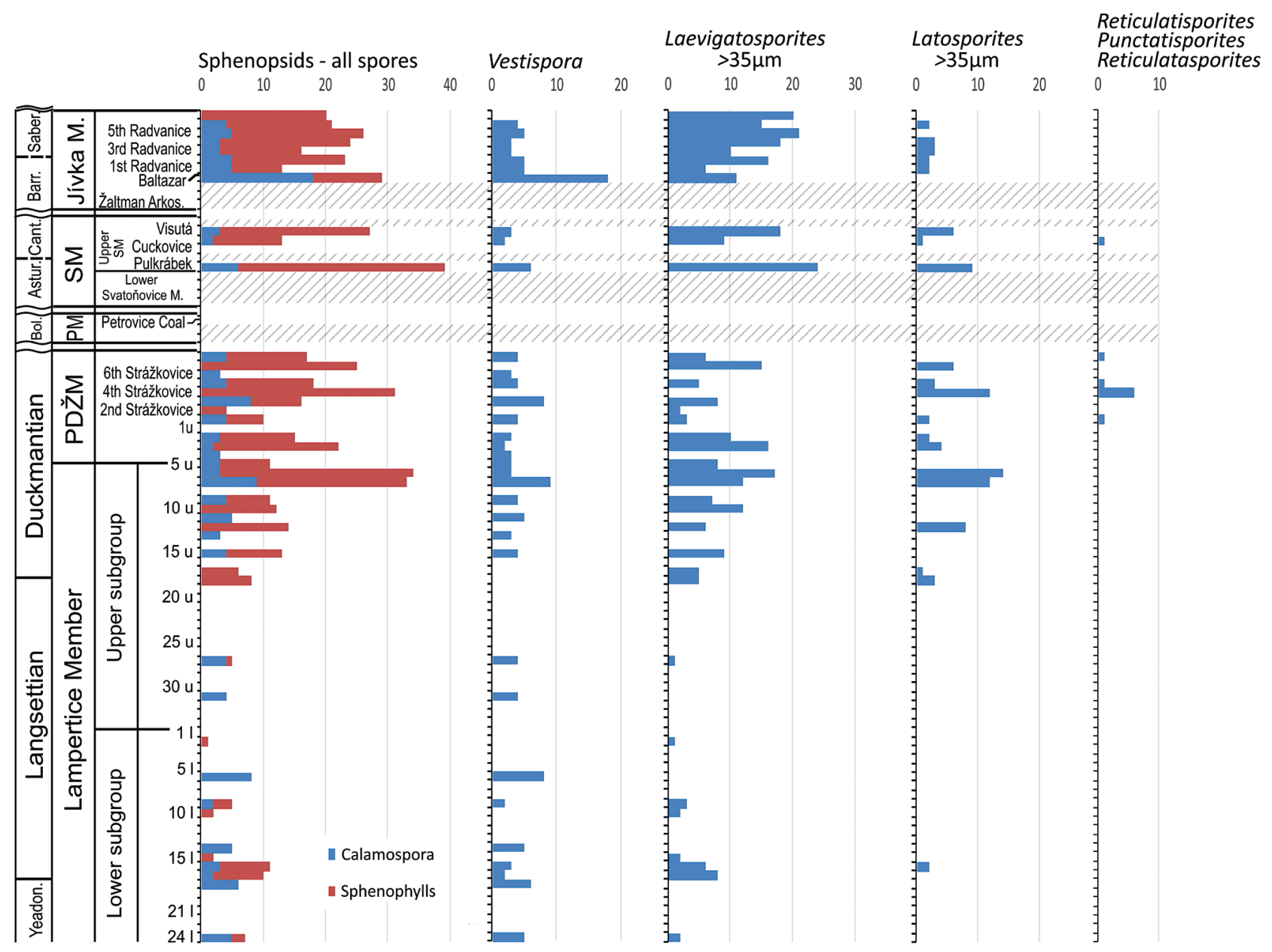

Figure 8. Percentage abundance of sphenopsid miospores in the Czech part of the Intra-Sudetic Basin. Abbreviations: Yeadon. - Yeadonian; PDŽM Prkenný Důl-Žd'árky Member; PM - Petrovice Member; SM - Svatoňovice Member; M. - member; CF - Chvaleč Formation; BF - Broumov Formation; Bol. - Bolsovian; Astur. - Asturian; Cant. - Cantabrian; Barr. - Barruelian; Saber. - Saberian.

spora) and sphenophyllalean [(Laevigatosporites and Latosporites more than $35 \mu \mathrm{m}$ in diameter, Vestispora, Dictyotriletes muricatus Kosanke, Punctatisporites obesus (Loose) Potonié \& Kremp and Reticulatasporites (Ibrahim) Potonié \& Kremp (opercula of the genus Vestispora)]. Similar to lycopsids, also sphenopsid plants are less diverse in macrofloral record comparing to diversity of their spores (Fig. 9). There is an increase in number of sphenophyllalean miospores from the bottom to the top of the Lampertice Member, i.e. from the level of the $12^{\text {th }}$ upper Lampertice coal seam. They reach only $2 \%$ from the $24^{\text {th }}$ to $13^{\text {th }}$ upper Lampertice coal seams but $12 \%$ above $11^{\text {th }}$ upper Lampertice coal seam (Fig. 8). This increase continues within the Prkenný Důl-Žd'árky (12\% on average) Svatoňovice (16\% on average) and the Jívka (14\% on average) members. Sphenophyllalean miospores are rarer within the Lampertice Member with only three genera. The most abundant sphenophyllalean miospores are the species of Laevigatosporites and Latosporites bigger than $35 \mu \mathrm{m}$. The only recorded sphenopsid megaspores of the Calamospora type are described in the Jivka Member (Kalibová in Tásler et al. 1979). Changes in diversity of sphenopsid miospores is more pronounced in sphenophylls whereas diversity of Calamospora born by calamites remains relatively stable from the Duckmantian to Saberian (Fig. 9). It indicates a significant proportion of long-ranging taxa among calamites and $\mathrm{Ca}$ lamospora.

\section{Miospores of ferns}

It is possible to divide fern miospores into marattialean zygopteridalean, botryopteridalean and gleicheniacean types (electronic supplement 1). There is a clear contrast between diversities of ferns recorded in plant compressions and miospores, the latter being up to several times higher (Fig. 5). Their diversities, however, show similar 

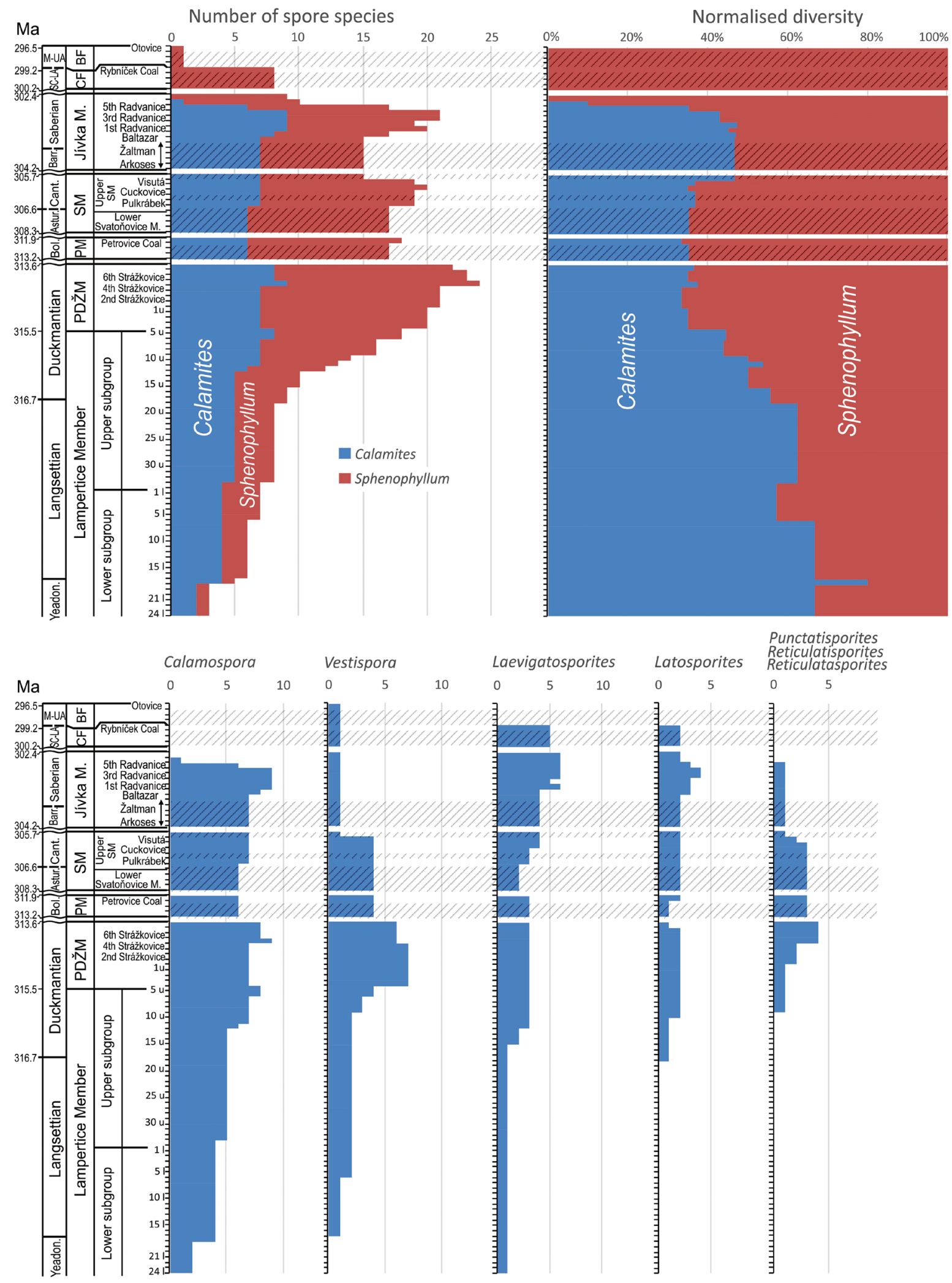

Figure 9. Species diversity of sphenopsid miospores in the Czech part of the Intra-Sudetic Basin. Abbreviations: Yeadon. - Yeadonian; PDŽM Prkenný Důl-Žd'árky Member; PM - Petrovice Member; SM - Svatoňovice Member; M. - member; CF - Chvaleč Formation; BF - Broumov Formation; Bol. - Bolsovian; Astur. - Asturian; Cant. - Cantabrian; Barr. - Barruelian; Saber. - Saberian; SC-LA - Stephanian C-lower Autunian; M-UA - middle-upper Autunian. 


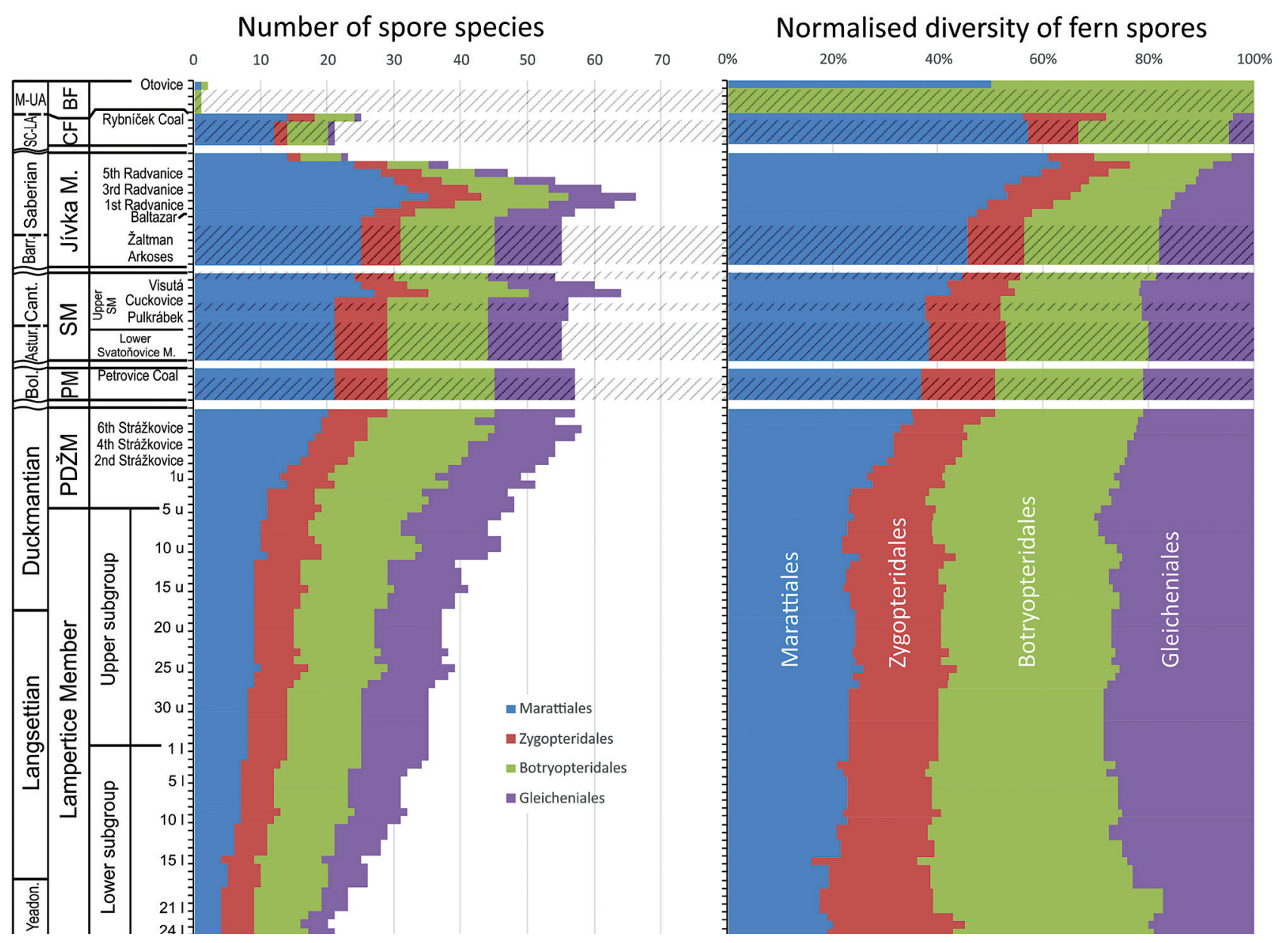

Figure 10. Species diversity of miospores produced by ferns in the Czech part of the Intra-Sudetic Basin. Abbreviations: Yeadon. - Yeadonian; PDŽM - Prkenný Důl-Žd'árky Member; PM - Petrovice Member; SM - Svatoňovice Member; M. - member; CF - Chvaleč Formation; BF Broumov Formation; Bol. - Bolsovian; Astur. - Asturian; Cant. - Cantabrian; Barr. - Barruelian; Saber. - Saberian; SC-LA - Stephanian C-lower Autunian; M-UA - middle-upper Autunian.

increase up to their maximum values in the late Duckmantian Strážkovice coal group. Above this level macrofloral diversity significantly drops and with some oscillation remains relatively low throughout the late Pennsylvanian and Asselian. In contrast, diversity of ferns in the palynological record above the Strážkovice coal group persists throughout most of Asturian and late Pennsylvanian times with further restricted increase in the Svatoňovice and Radvanice coal-bearing intervals (Figs 5, 10). This late Pennsylvanian maximum of fern diversity recorded in miospore assemblages corresponds to general dominance of ferns, especially maratiallean tree ferns, to basinal landscape in this time interval (Pfefferkorn \& Thomson 1982, DiMichele 2014). The higher palynological diversity can be partly explained by the production of more than one miospore taxon produced by each species of tree fern with Pecopteris-type of foliage (e.g. Balme 1995, Bek \& Opluštil 1998). It may also reflect conservatism of their foliage where different biological species produced morphologically very similar foliage hardly distinguishable in fragmentary fossil record.

The general feature of marattialean miospores is their increasing number from $2 \%$ on average in the Lampertice to the $18 \%$ in the Jívka members (Fig. 11). The most abundant are smallest (less than $35 \mu \mathrm{m}$ in diameter) species of genera Laevigatosporites and Latosporites. It is interesting to note that local abundance $(20 \%)$ of the genus Punctatosporites within $8^{\text {th }}$ Strážkovice Coal Seam represents its maximum percentage of the whole profile. The number of miospore genera of marattialeans is more or less same through the profile of the basin (seven to eight genera). Miospores of zygopterid ferns reach 7.5\% on average from the Lampertice to the Jívka members and are represented by seven genera. Generally, these miospores are the most abundant in older strata of the Lampertice Member with six genera that make up 10\% on average. Zygopterid miospores reach five percent on average in the Prkenný Důl-Žd'árky members and slightly 
increased number is recorded in the Jívka ( $8 \%$ on average) Member. The most abundant zygopterid miospore type is the genus Apiculatisporites with local abundance within the $12^{\text {th }}$ lower coal seam (39\%).

Botryopterid miospores are represented by six genera and make $11 \%$ on average from the Lampertice to the Jívka members (electronic supplement 1). The general pattern is similar to that of zygopterid miospores, i.e. the number of botryopterid miospores slightly decreases from the Lampertice ( $13 \%$ on average) to the Jivka ( $8 \%$ on average) members but the number of genera is comparable (Fig. 11). Gleicheniacean miospores are represented only by two genera, Leiotriletes and Triquitrites that reaches $4.8 \%$ along the profile and their number decreases from the Lampertice ( $7 \%$ on average) to the Jívka ( $2 \%$ on average) members. Generally, miospores of fern origin reach their maximum within the Svatoňovice Member (46\%) and their minimum in the Prkenný Důl-Žd'árky Member (30\%).

\section{Gymnosperm pollen}

\section{Cordaitalean pollen}

Cordaitalean pollen consists of only eight Florinites species and makes $3.3 \%$ on average from the Lampertice to the
Jívka members. Increased numbers of Florinites from the Lampertice ( $1 \%$ on average) to the Jívka members $(5 \%$ on average) are observable. Local maximum of Florinites is recorded in the 18th upper coal seam at $8^{\text {th }}$ Strážkovice Coal Seam (both of them 8\%). Surprisingly, the stratigraphic range of Florinites is smaller than of compressions of its parent plants (Fig. 5; Opluštil et al. 2017). The former enters the palynological record below the mid of the Lampertice Member in early Langsettian and makes its last occurrence in the Rybníček Coal of Stephanian Clower Autunian age (late Gzhelian). In compression floras cordaitalean remains occur throughout the entire studied section. Between late Duckmantian and Saberian times, the number of palynological taxa usually mostly exceeds macrofloral record, except the $3^{\text {rd }}$ Strážkovice Coal (Duckmantian) where exceptionally high number of cordaitalean species was distinguished from cuticular analysis of their leaves (Šimůnek \& Libertín 2006, Šimůnek 2007).

\section{Coniferalean pollen}

Coniferalean pollen (genera Lueckisporites and Potonieisporites Bharadwaj) occur only in the Jívka Member where they reach only $1 \%$ on average (electronic supplement 1, 2; Figs 4, 12). Lueckisporites occurs only in the $4^{\text {th }}$ Radvanice Coal Seam where Potonieisporites reached

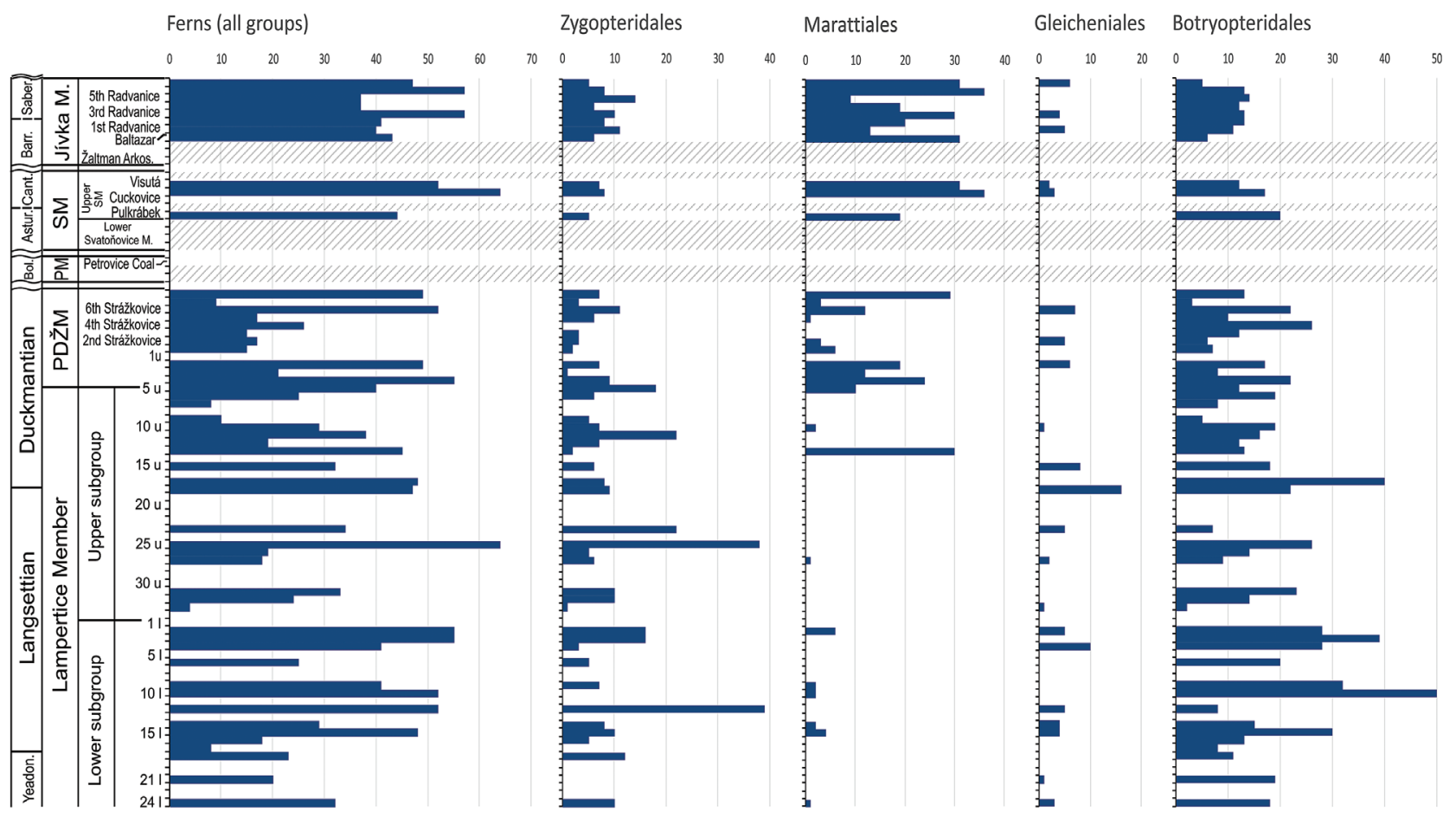

Figure 11. Percentage abundance of fern miospores in the Czech part of the Intra-Sudetic Basin. Abbreviations: Yeadon. - Yeadonian; PDŽM Prkenný Důl-Žd’árky Member; PM - Petrovice Member; SM - Svatoňovice Member; M. - member; CF - Chvaleč Formation; BF - Broumov Formation; Bol. - Bolsovian; Astur. - Asturian; Cant. - Cantabrian; Barr. - Barruelian; Saber. - Saberian. 
its maximum (4\%). Cumulative stratigraphic ranges of these two genera spans the interval between the Saberian and Asselian that surprisingly does not fit with the first occurrence of conifer impressions in the late Asturian red beds of the early Svatoňovice Member (Opluštil et al. 2017). Instead, their pollen first enters the palynological record in the Radvanice coal group of Saberian age (Figs $4,12)$. This may be due to fact that palynological samples included nearly exclusively coal or carbonaceous clastics from coal-bearing intervals whereas no palynological data has been obtained from red beds. Another inconsistency between macro- and microfossil records of conifers concerns very low diversity of their pollens (one species) in the Asselian comparing to ten species identified in plant compressions (electronic supplement 1, Fig. 4).

\section{Pollen of cycadaleans}

Cycadalean pollen are represented only by the species Remysporites magnificus (Horst) Potonié \& Kremp that rarely (three records) occurs only within the Lampertice Member.

\section{Pollen of pteridosperms}

Pollen of pteridosperms are very rarely recorded in miospore and pollen assemblages from Pennsylvanian times (Willard 1993, Peppers 1996, Eble et al. 2003, Willard et al. 2007). In the Czech part of the Intra-Sudetic Basin only very few of them have been found. They include genera Vittatina Luber ex Jansonius, Guthoerlisporites Bharadwaj and possibly Wilsonites Kosanke which have been reported from pollen organs possibly of peltasperm affinity (Gomankov \& Meyen 1986, Poort \& Kerp 1990, Balme 1995, Dimitrova et al. 2011) although the affinity of Wilsonites is only presumed (Meyen 1987). They appear for the first time in the Prkenný Důl-Žd'árky Member (electronic supplement 1) but they are most abundant in the Jívka Member with 1\% on average. The genus Wilsonites is the most common with its maximum $(4 \%)$ in the $6^{\text {th }}$ Radvanice Coal Seam. Wilsonites enters the palynological record in the upper Duckmantian Strážkovice coal group followed by Vittatina in the Bolsovian Petrovice Coal and by Guthoerlisporites in the Saberian Radvanice coal group. It is, however, not until the Cantabrian Svatoňovice coal group where this pollen becomes relatively more common and diverse (electronic supplement 1). Completely absent from palynological record is pollen of Medullosales, Lyginopteridales and Callistophytales. Very unusual but of highest importance is the occurrence of Vittatina that is considered to be of peltaspermales affinity (e.g. Poort \& Kerp 1990) in the Petrovice Coal of Bolsovian age (electronic supplement 1).
It is more typical for late Pennsylvanian and Permian, although in the Sydney coalfield of eastern Maritime Canada occurs in the Cantabrian (Dimitrova et al. 2011). The Petrovice Coal is only several tens of centimetres thick, composed of high-ash coal to carbonaceous mudstone. Its local extent suggests possible coexistence of peat swamp precursor with well-drained habitats in the basin landscape (possibly lowland) during late Bolsovian times. This coincides with the earliest dry interval of increased seasonality/aridity (Roscher \& Schneider 2006). Vittatina is absent in the palynological record of the Svatoňovice (Cantabrian) and Radvanice (Saberian) coal groups and makes its second occurrence in the late Gzhelian Rybníček Coal of the Vernéřovice Member (electronic supplement 1).

\section{Miospores and pollen of unknown affinity}

Miospores of unknown affinity consist of 37 genera and reach $13 \%$ on average from the Lampertice to the Jívka members. Their general pattern is clearly characterised by decreasing numbers in the Lampertice ( $24 \%$ on average) to the Jívka (6\% on average) members. The most important and abundant is the genus Savitrisporites that contitutes $12 \%$ in the Lampertice Member with its maximum in the $17^{\text {th }}$ lower coal seam. Miospores of unknown affinity are generally more abundant in late Langsettian and Duckmantian part of the succession. We assume that most of these taxa may represent various ferns that reach their maximum diversity in plant compression record of this interval.

\section{Palynozonation and comparison}

Several Pennsylvanian palynozones have been proposed during last fifty years (e.g. Alpern \& Liabeuf 1966, Smith \& Butterworth 1967, Alpern et al. 1969, Grebe 1972, Coquel et al. 1976, Wijhe \& Bless 1974, Kmiecik 1978, Górecka \& Górecka-Nowak 1979, Dolby 1988, Peppers 1996, Dimitrova 2004) including the most cited western European zonation published by Clayton et al. (1977). The ground principle of palynozonation is the combination of first appearances and last records of one or more taxa, sometimes combined with some type of biozones, mostly acmezones. Palynozones covering more than one basin and/or country (e.g. Coquel et al. 1976, Clayton et al. 1977) cannot be so precise and generally valid as local ones.

Much better is detail division of only one basin or coalfield into palynozones and subzones (e.g. Dimitrova 2004, McLean et al. 2005) because characteristics of stratigraphically important data of spore and pollen species 


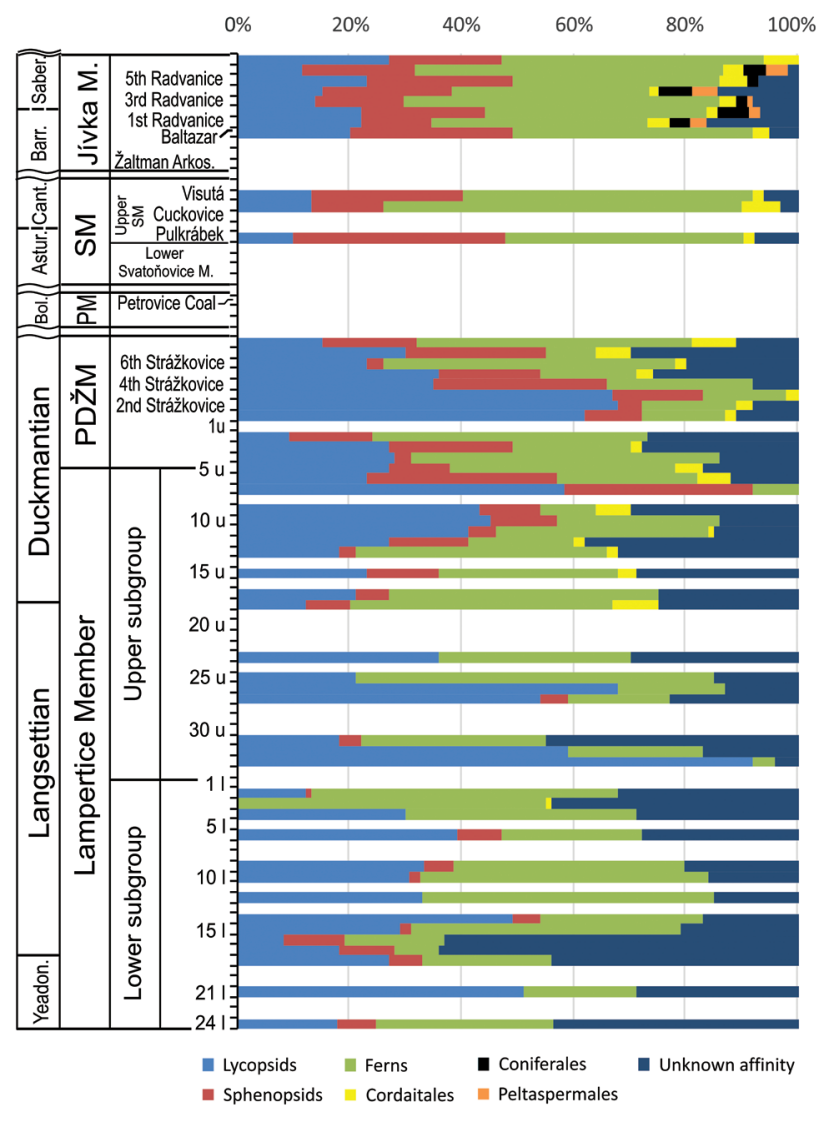

Figure 12. Percentage abundancy of major plant groups miospores in the Czech part of the Intra-Sudetic Basin. Abbreviations: Yeadon. Yeadonian; PDŽM - Prkenný Důl-Žd'árky Member; PM - Petrovice Member; SM - Svatoňovice Member; M. - member; CF - Chvaleč Formation; BF - Broumov Formation; Bol. - Bolsovian; Astur. Asturian; Cant. - Cantabrian; Barr. - Barruelian; Saber. - Saberian.

are homogeneous. It is the reason why here we do not adopt some of existed broad international palynozones but propose a new zonation only for the Czech part of the Intra-Sudetic Basin.

Herein the proposed palynozones are based on the combination of first occurrences and last occurrences of species that occur commonly in the basin and defined by absolute age and plant zonation.

The first Acanthotriletes echinatus-Murospora palynozone covers the Lampertice Member sedimentation interval, i.e. about 320-315 Ma. This palynozone corresponds to the upper part of the Pecopteris aspera, the whole $\mathrm{Ca}$ lymnotheca hoeningshausii and lower part of the Lochopteris rugosus plant zones (Wagner \& Alvárez-Vásques 2010). The genera Foveosporites Balme, Radiizonates and Waltzispora and species Acanthotriletes echinatus (Knox) Potonié \& Kremp, Remysporites magnificus, Cingulizonates loricatus (Loose) Butterworth \& Smith and Murospora sulcata (Waltz) Jachowicz occur only here. The increasing number of spores of Apiculatisporites,
Punctatisporites, Ahrensisporites, Bellispores Artüz and Savitrisporites from the bottom to the top of the member is a characteristic of this palynozone. Most Acanthotriletes species are restricted to this interval.

Vestispora magna-Anapiculatisporites spinosus palynozone is restricted to the Prkenný Důl-Žd'árky Member, i.e. about 315-314 Ma. This palynozone corresponds to the upper part of the Lonchopteris rugosa and the lowermost part of the Paripteris linguaefolia plant zones (Wagner \& Alvárez-Vásques 2010). Some species including Acanthotriletes triquetrus Smith \& Butterworth, Alatisporites hexalatus Kosanke, Apiculatisporites abditus (Loose) Potonié \& Kremp, Cingulizonates tuberosus Dybová \& Jachowicz, Cristatisporites indignabundus (Loose) Staplin \& Jansonius, Vestispora magna (Butterworth \& Williams) Wilson \& Venkatachala, V. laevigata and the genera Tripartites and Kuhlensisporites Kruszewska are restricted to only here. Several species have their last occurrence including Anapiculatisporites cf. spinosus, Bellispores nitidus (Horst) Sullivan, Dictyotriletes bireticulatus (Ibrahim) Potonié \& Kremp, Stellisporites inflatus Alpern, Mooreisporites cf. inusitatus Neves and Savitrisporites nux (Butterworth \& Williams) Smith \& Butterworth. The maximum of Densosporites, Cristatisporites, Acanthotriletes Naumova, Punctatosporites are characteristic, as well as the abundance of Endosporites and increasing number of specimens of Planisporites (Knox) Potonié \& Kremp.

The Wilsonites kosankei-Torispora granulata/T. undulata palynozone corresponds to the Svatoňovice Member, i.e. about 308-306 Ma. This palynozone corresponds to the upper part of the Crenulopteris acadica and the lower part of the Odontopteris cantabrica plant zones (Wagner \& Alvárez-Vásques 2010). The species Cirratriradites annulatus, Lycospora micrograna Hacquebard \& Barss, Triquitrites pulvinatus Kosanke and all key taxa occur only here and Speciososporites laevigatus Alpern, Punctatosporites rotundus and P. pygmaeus have their first occurrence. The abundance of Florinites and smallest forms of Laevigatosporites and Latosporites is characteristic of this palynozone.

Cadiospora magna-Potonieisporites palynozone is restricted to the Jívka Member, i.e. about 304-303 Ma. This palynozone corresponds to the upper part of the Crenulopteris lamuriana and the lower part of the Alethopteris zeileri plant zones (Wagner \& AlvárezVásques 2010). Some species including Aumancisporites striatus Alpern, Cadiospora magna f. maior, C. magna f. minor, C. magna f. plicata, Gillespieisporites discoideus (Kosanke) Kalibová, Guthoerlisporites magnificus Bharadwaj, Illinites unicus Kosanke, Latensina triletus Alpern, Lundbladispora gigantea Alpern, Punctatosporites oculus Smith \& Butterworth, Speciososporites plicatus Alpern, Thymospora thiessenii (Kosanke) 
Wilson \& Venkatachala and genera Disaccites Cookson and Lueckisporites are restricted to only here. Several species make their first appearance here including $E$. globiformis (Ibrahim) Schopf et al., Kosankeisporites elegans (Kosanke) Bharadwaj and Potonieisporites elegans (Wilson \& Kosanke) Wilson \& Venkatachala. The most prominent feature is the increasing percentage of the smallest monoletes (Punctatosporites, Thymospora, Speciososporites, Torispora and small forms of Laevigatosporites and Latosporites).

Lastly, the Spinosporites spinosus-Potonieisporites novicus palynozone is restricted to the Vernérovice Member, i.e. 299-301 Ma. This palynozone corresponds to the lower part pf the Autunia conferta plant zone (Wagner \& Alvárez-Vásques 2010). Both key species and Punctatisporites baccatus Hoffmeister et al. and $P$. provectus Kosanke make their first appearance here. The species Apiculatisporites baccatus, A. baccatus f. trebechovensis Kalibová, Florinites piérartii Kalibová, Punctatisporites provectus, Spinosporites spinosus and Thymospora verrucosa (Alpern) Wilson \& Venkatachala are restricted to only here.

It is not possible to assign the assemblages of the Petrovice and Olivětín members to any palynozone due to very poor miospore and pollen record.

The dispersed miospore and pollen assemblages from CPISB were compared with those described from the Polish part of the same basin. This comparison included assemblages described by Górecka (1968, 1969), Górecka \& Górecka-Nowak (1990). A local palynozonation framework was not proposed and these authors employed the palynozones suggested by Clayton et al. (1977). The Yeadonian FR palynozone is characterised by the abundance of Crassispora kosankei, Stenozonotriletes triangulatus Neves, Schulzospora rara Kosanke and the appearance of Reticulatisporites reticulatus (Ibrahim) Ibrahim. Only the genus Laevigatosporites and the species Crassispora kosankei (Potonié \& Kremp) Smith $\&$ Butterworth also occur in the Czech part of the basin. The lower Langsettian RR palynozone contains the first appearance of Cingulizonates loricatus and Dictyotriletes bireticulatus, the genus Florinites and the species Cirratriradites saturni are common. Only the genus Laevigatosporites and the species Dictyotriletes bireticulatus and Cirratriradites saturni occur in the lower part of the Lampertice Member in the Czech part of the basin. The Langsettian RA palynozone is characterised by the appearance of the species Endosporites globiformis and the genus Punctatosporites. Florinites mediapudens (Loose) Potonié and Kremp, Raistrickia fulva Kosanke and Radiizonates aligerens Knox are common. Endosporites globiformis appears in stratigraphically younger sediments in the Czech part of the basin and Radiizonates has not been recorded.
The Duckmantian NJ palynozone is characterised by the appearance of Triquitrites sculptilis and Punctatosporites granifer. The character of this assemblage is similar to that in the Czech part of the basin. The Bolsovian SL palynozone contains the first occurrences of several taxa, including Torispora securis, Vestispora fenestrata and Westphalensisporites irregularis. Only Vestispora fenestrata and Westphalensisporites irregularis also occur in the Petrovice Member in the Czech part of the basin.

The OT palynozone includes Asturian and Barruelian strata, and the species Triquitrites bransonii and T. exiguus and the genus Thymospora first appearance in this zone. This assemblage also occurs in strata of the same age in the Czech part of the basin. The ST palynozone spans the latest Stephanian A and the entire Stephanian B, and is characterised by the first appearance of Polymorphisporites Alpern, Spinosporites spinosus, Latensina, Cadiospora magna and Thymospora verrucosa. A similar assemblage also occurs in age equivalent strata in the Czech part of the basin. The uppermost NBM palynozone of Stephanian $\mathrm{C}$ and $\mathrm{D}$ age is similar to the underlying palynozone, and can be broadly compared to both equivalents in the Czech part of the basin. On the whole, the dispersed miospore and pollen assemblages from the Polish part of the IntraSudetic basin are similar to those from the Czech part, particularly in stratigraphically younger members (i.e. from the level of the NJ palynozone, equivalent to the Prkenný Důl-Žd'árky Member).

Clayton et al. (1977) proposed twenty-five palynozones from the Famennian to the Autunian of Western Europe. Later this scheme was slightly changed, e.g. by Owens et al. (2005). The lower part of Yeadonian FR Raistrickia fulva-Reticulatisporites reticulatus palynozone is marked by appearance of e.g. Ahrensisporites beeyleyensis Neves, Dictyotriletes muricatus, Reticulatisporites reticulatus and Bellispores nitidus. Other typical species are Cirratiradites saturni, Mooreisporites fustis Neves and Spelaeotriletes arenaceus Neves \& Owens. All of these species are absent in the lower part of the Lampertice Member. SS Triquitrites sinani-Cirratriradites saturni palynozone covers the lower part of Langsettian and the most typical is the occurrence of genera Ahrensisporites, Triquitrites and Cirratriradites saturni, and increasing number of Latosporites. The first two genera occur in a low numbers in stratigraphically comparable strata in the Czech part of the Intra-Sudetic Basin, but higher a percentage of Latosporites is recorded in younger strata here. Radiizonates aligerens (RA) palynozone is restricted to the upper Langsettian. The key species appear for the first time here together with Punctatosporites minutus Ibrahim and an increased percentage of the whole genus. Other typical taxa included Kraeuselisporites ornatus (Neves) Owens et al., Dictyotriletes bireticulatus and the genus Disaccites. Only 
Punctatosporites minutus is recorded in stratigraphically comparable strata in the Czech part of the Intra-Sudetic Basin. Microreticulatisporites nobilis-Florinites junior (NJ) palynozone covers the whole Duckmantian and lowermost Bolsovian. Both of the key species appeared here for the first time, and the most typical is abundance of Lycospora, Densosporites, Vestispora cancellata (Dybová \& Jachowicz) Wilson \& Venkatachala and maximum of Dictyotriletes bireticulatus and Cirratriradites saturni. This characteristic is similar to assemblages of the same stratigraphical level in the Czech part of the Intra-Sudetic Basin. Torispora securis-T. laevigata (SL) palynozone is restricted almost to the whole Bolsovian. The species Vestispora fenestrata, Potonieisporites gelriaensis Bless et al., Disaccites striatiti and Lundbladispora gigantea Alpern appear for the first time and Lycospora, Torispora and Punctatosporites are abundant. Vestispora fenestrata makes its first appearance in stratigraphically older strata in the Czech part of the Intra-Sudetic Basin, Disaccites striatiti Pant and Potonieisporites gelriaensis Bless et al. never been described here. Thymospora obscura-T. thiessenii (OT) palynozone is restricted to the uppermost Bolsovian, the whole Asturian and lower Barruelian strata. Typical is the increasing number of the smallest monoletes, together with a common occurrence of Lundbladispora gigantea, Vestispora fenestrata and Westphalensisporites irregularis. Increasing number of smallest monoletes appears in stratigraphically younger strata in the Czech part of the Intra-Sudetic Basin. Angulisporites splendidus-Latensina trileta (ST) palynozone covers upper part of the Barruelian and almost the whole Saberian. The smallest monoletes are still abundant together with Lycospora and Densosporites. The genera Cheiledonites Doubinger and Vittatina appear for the first time and typical are Westphalensisporites irregularis, Disaccites non striatiti, Candidispora spp. and Lundbladispora gigantea. Cheiledonites and Disaccites are not recorded in the Czech part of the Intra-Sudetic Basin but other taxa occur in the Jívka Member. Potonieisporites novicus-bhardwajii-Cheiledonites major (NBM) palynozone is restricted to the uppermost Saberian and to middle and upper Autunian. Smallest monoletes are again abundant and Triquitrites, Lundbladispora gigantea, Potonieisporites, Cheiledonites and Polymorphisporites Alpern occur regularly. The smallest monoletes are rarely recorded in stratigraphically comparable strata in the Czech part of the Intra-Sudetic Basin and generally these assemblages are not similar to that of the Vernérovice Member because only a few of above-mentioned taxa also occur here. Vittatina costabilis (VC) palynozone covers lower Autunian but the number of miospore and pollen taxa in the Czech part of the Intra-Sudetic Basin at this stratigraphically level is too small to allow any useful comparison. Generally, it is possible to state that only dispersed miospore and pollen assemblages of NJ palynozone as described by Clayton et al. (1977) is similar to those from stratigraphically comparable strata in the Czech part of the Intra-Sudetic Basin, the characteristics of the other palynozones are different.

Generally, it is possible to conclude that dispersed miospore and pollen assemblages from Yeadonian to Autunian of Europe are not easily comparable with those in CPISB, except for assemblages from the Polish part of the basin and surprisingly those reported from the Limburg area in the Netherlands (Wijhe \& Bless 1974).

\section{Vegetation patterns estimated from quantitative palynological data}

In the "grey" coal-bearing intervals the number of miospores per sample was often high enough to quantify percentages of genera (electronic supplement 2) and in turn of major plant groups which produced them. Although these quantified palynological spectra cannot be directly interpreted in term of abundancy of populations of parent plant species (Willard 1993, Willard \& Phillips 1993), fluctuation of their values throughout the studied succession may reflect temporal vegetation changes of local (e.g. basinal) and regional scales. This, in turn provides a base for estimations of vegetation patterns and for comparison with similar data from other coalfields of tropical Pangea. Only a brief comparison is provided; a more detailed one is outside the scope of the paper.

The study by Peppers (1996) for the North American coalfields shows a prominent palynological change just above the Middle-Late Pennsylvanian boundary, expressed mainly as a change in the percentage of spores of arborescent lycopsids versus tree ferns. In Pepper's data, the Lycospora produced by lepidodendrid lycopsids clearly dominate the Langsettian to Duckmantian palynological assemblages (usually 70-90\%), starting slowly and irregularly decreasing in the Bolsovian and especially in Asturian, and suddenly dropping nearly to zero just above the Middle-Late Pennsylvanian boundary. The decrease in Lycospora is mainly compensated by the increase in miospores of tree ferns that become dominant during the Late Pennsylvanian in the Appalachian and Interior coalfields (Peppers 1996, Eble 2002, Eble et al. 2013). This trend agrees with floral changes at this boundary as identified from plant compressions and coal balls (Pfefferkorn \& Thompson 1982, Phillips et al. 1985, Pfefferkorn et al. 2008, DiMichele 2014).

A slightly different scenario shows coalfields in Europe and North Turkey. Their Langsettian to Asturian palynofloras are very similar to those in the Appalachian and Interior coalfields (Cleal et al. 2010). Coals of this age 
in the Ruhr (Jasper et al. 2010, Hartkopf-Fröder 2015), Saar (Peppers 1996), Pennines (Smith \& Butterworth 1967), South Wales (Dimitrova et al. 2005), Upper Silesia (Górecka 1968, 1969; Górecka \& Górecka-Nowak 1990; Bek 2008), Dobrogea (Dimitrova \& Cleal 2007), Zonguldak-Amasra (Ergönül 1960, Opluštil et al. 2018) and Polish part of the Intra-Sudetic basins (Nowak \& Górecka-Nowak 1999) are also dominated by spores of arborescent lycopsids, mainly by Lycospora. Although the precise percentage of palynomorphs produced by major plant groups may differ spatially and temporarily, the available data suggest an ecologically stable condition during the humid part of glacial/interglacial cycles, which supported the formation of extensive peat swamps across most of tropical Pangea (Falcon-Lang \& DiMichele 2010, Cecil et al. 2014, DiMichele 2014, Opluštil et al. 2019). There is, however, a change from the Peppers (1996) scenario for the Appalachian and Interior coalfields of the USA at the Middle-Late Pennsylvanian boundary. Although an existing palynological data from European coalfields may differ in percentage of individual palynological taxa around the Middle-Late Pennsylvanian transition, they commonly show a drop in content of arborescent lycopsid spores (mainly in Lycospora) in spore and pollen assemblages. However, the decrease is not so drastic and Lycospora still remains quite a common part of palynological assemblages in many upper Pennsylvanian European coals till the end of Pennslyvanian (e.g. Châteauneuf et al. 1992, Pešek 2004). However, the main part of the palynological assemblages still consists of spores of tree ferns and in middle to late upper Pennsylvanian coals and lacustrine horizons number of conifer pollen grains increases.

Examination of our Pennsylvanian palynological data from the Intra-Sudetic Basin shows a similar trend to North American and European coalfields from Yeadonian to Asturian. Differences in the percentage of miospores between basins and within individual basins, however, exist. As an example, in the Yeadonian and Langsettian part of the succession of the Intra-Sudetic Basin the Lycospora content varies between 10 and $90 \%$ of the palynological assemblages of discrete coals with the common values within an interval from 20 to $40 \%$ (Fig. 6). In Duckmantian coals, the percentage of Lycospora varies between 5 and $40 \%$ being $20 \%$ in average. At the Westphalian-Stephanian boundary (broadly correlated with the Middle-Late Pennsylvanian boundary in the North America) in the Svatoňovice Member, there is a decrease in the Lycospora content to values around $10 \%$, but no disappearance like in the United States coalfields (Figs 7,12 ). Values $\sim 15 \%$ are typical for samples from the Saberian Radvanice coal group, our youngest quantified data. The miospores produced by marattialean tree ferns are often absent in the palynological samples through the
Yeadonian to the lower Duckmantian coals, except for the $13^{\text {th }}$ coal of the upper subgroup (Jan Šverma Mine coal group) where their content reaches $30 \%$ (Figs 7, 12). However, these miospores become more common in the upper Duckmantian Strážkovice coal group although most values still vary between 10 and $20 \%$. In the upper Pennsylvanian coals of the Svatoňovice and Radvanice groups the percentage of miospores of marattialean ferns oscillates between 10 and $35 \%$ being $24 \%$ in average. This increase is accompanied by the first appearance of conifer pollen grains in the Radvanice coal group (Saberian), although their content is in few percent only (see Fig. 12). Palynological data from the Czech part of the Intra-Sudetic Basin, therefore fit much better to similar data from European coalfields that to those in the North America, where lepidodendrid lycospid disappear from the macrofloral and microfloral records.

\section{Temporal changes in miospores, pollen grains, and plants during Pennsylvanian and early Permian}

We attempt to reconstruct temporal changes in vegetation patterns within $\sim 21 \mathrm{Ma}$ interval between 318 and $297 \mathrm{Ma}$ from the middle Bashkirian to lower Asselian in the Czech part of the Intra-Sudetic Basin, based on combination of palynomorph and macrofloral data. Their comparison (Figs 4, 5) shows not only two to five times higher diversity of miospores and pollen (except the Asselian), but also reveals prominent differences in diversities between coalbearing or lacustrine strata and coal-barren red beds. The former represents major windows of preservation when the basin landscape was colonized by flora of peat-forming wetlands populated by evolutionarily conservative plant lineages (DiMichele 2014, Looy et al. 2014). The latter are intervals of dominantly oxidative conditions unfavourable for fossilization of plant remains (Gastaldo \& Demko 2011, Opluštil et al. 2017). The macroflora in the red beds is, therefore very poor, and palynomorphs are absent and only interpolated by the palynological data currently available for these intervals. However, these interpolated palynological data records implies wetland taxa surviving the period of more or less pronounced climatic seasonality between adjacent coal-bearing intervals bracketing red bed succession. It supports the idea that these wetland floras are characterised by a compositional conservatism (DiMichele \& Phillips 1996). In contrast, cordaitalean leaves and conifer shoots dominate poorly preserved plant impressions found in red beds, and are accompanied only with subordinate wetland elements, mostly calamites (Opluštil et al. 2017). The predominance of gymnosperms in red beds suggests existence of dryland habitats in the basin lowland. However, interpolated palynological 
data show also an unexpectedly high diversity of free sporing plants typical of wetlands in adjacent coal-bearing windows. Therefore, we assume that during these intervals of increased climatic seasonality enhancing well-drained/ dryland habitats and excluding significant peat formation, wetland flora probably survived in small refugia scattered along rivers running through basin lowland (Falcon-Lang \& DiMichele 2010). This is supported by exceptional findings of lepidodendrid leafy shoots (Opluštil et al. 2017). In addition, occasional palynological data from similar red bed successions elsewhere in the tropical Pangea provided palynological spectra dominated by gymnosperm (cordaitalean and conifer) pollen and thus also confirming colonization of basin lowland by dryland plant biome (Dolby et al. 2011, Hoof et al. 2013).

Keeping all these facts in mind, the following model of temporal changes in composition of floras, and their vegetation patterns in the Intra-Sudetic Basin can be suggested.

Palynological data across the Yeadonian to early upper Duckmantian coal-bearing interval (Lampertice and most of the Prkenný Důl-Žd'árky members except its top) shows high species stability with only minor changes between neighboring coal beds (Fig. 13). The changes in number of palynological taxa usually do not exceed $10 \%$ ( $<8$ species) but may increase to $15 \%$ in upper part of this interval. Most of them represent origination of new species resulting in increase in diversity of palynomorphs similar to that observed in macrofloral data (Figs 13, 14). It suggests that this $\sim 6 \mathrm{Ma}$ interval is a period of ecological and species stability and highest species diversity dominated by conservative plant lineages centred to widespread wetland habitats. Arborescent lycopsids reached their highest species diversity and their populations were

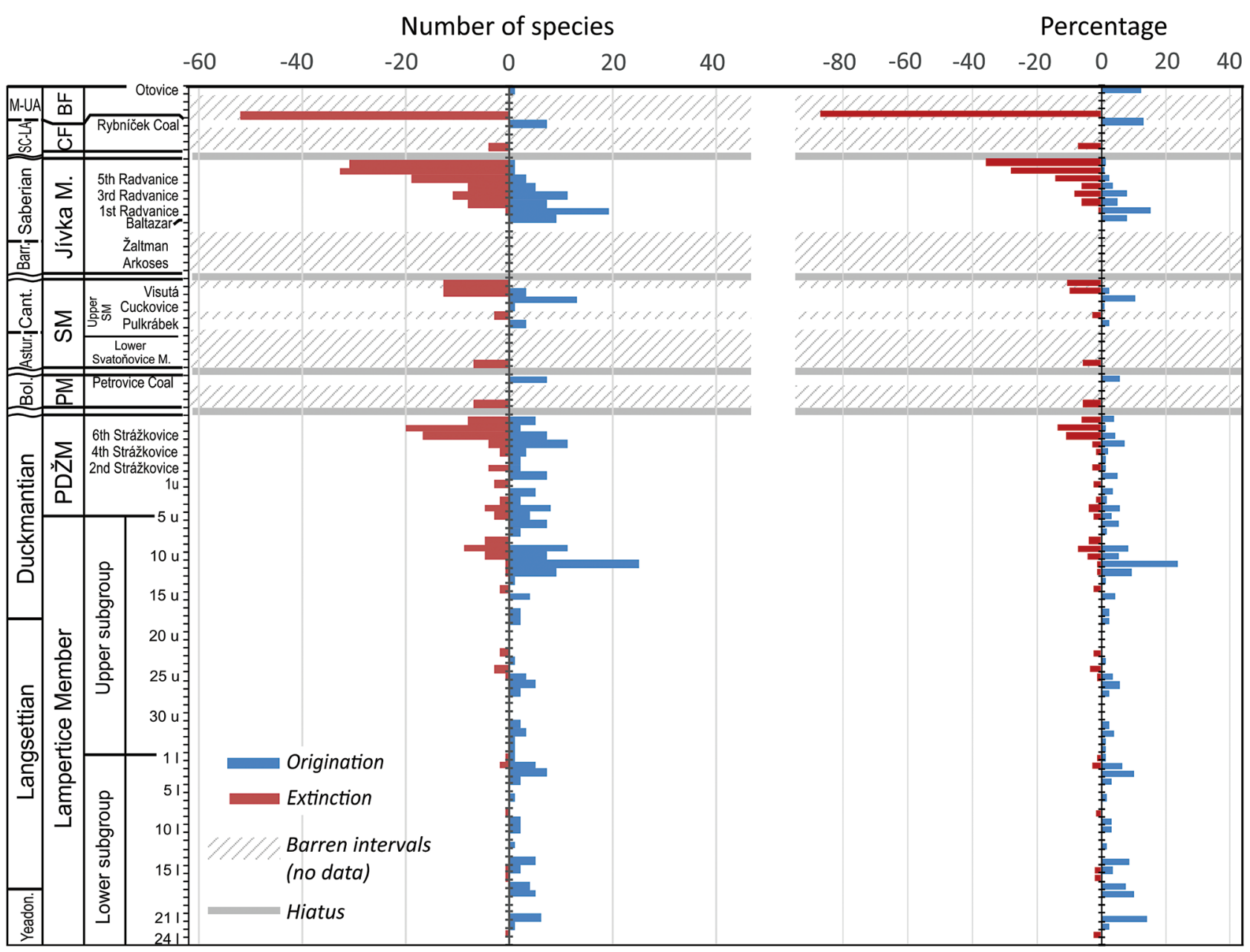

Figure 13. Origination and extinction of miospore taxa expressed in number of species (left) and in percentage of overall diversity (right) in the Czech part of the Intra-Sudetic Basin. Abbreviations: Yeadon. - Yeadonian; PDŽM - Prkenný Důl-Žd'árky Member; PM - Petrovice Member; SM - Svatoňovice Member; M. - member; CF - Chvaleč Formation; BF - Broumov Formation; Bol. - Bolsovian; Astur. - Asturian; Cant. Cantabrian; Barr. - Barruelian; Saber. - Saberian; SC-LA - Stephanian C-lower Autunian; M-UA - middle-upper Autunian. 
at the maximum, as indicated by abundancy of their remains in compressions (Šetlík 1977, Libertín et al. 2009, Opluštil et al. 2017) and in quantified palynological record (Figs 7, 12). They dominated the landscape together with pteridosperms and calamites. However, the small sphenopteroid ferns and sphenophylls (Fig. 4) were also very diverse. The palynological data also indicates the presence of sub-arborescent and herbaceous, e.g. lycopsids either not reported (e.g. Omphalophloios and Selaginella types) or very rare (Polysporia Newberry) in the macrofloral record (Bek et al. 2008, Opluštil et al. 2017). This interval also hosts the highest diversity of miospores of unknown affinity (electronic supplement 1 ; Figs 4, 5). There is, however, no indication of conifers in this interval or other plants typical of Late Pennsylvanian and Early Permian landscape dryland biome (Looy at al. 2014, Opluštil et al. 2017).

The decline in species diversity in both, palynological and macrofloral records in upper part of the Strážkovice coal group (Figs 4, 13 and 14) suggests that this might be a natural process possibly driven by an onset of a shift to more seasonal climate (Roscher \& Schneider 2006). It affected mostly populations and diversity of lycopsids (in both types of fossil records) and was less pronounced among sphenopsids, ferns and pteridosperms (Fig. 4). A similar drop in plant diversity at corresponding levels also occurs in the central Pennines (Cleal 2005). Palynological data at the top of this interval also show similar decline in diversity mainly affecting lycopsid- and fern-derived species and taxa of unknown affinity.

Following the lower Bolsovian hiatus, deposition continued in the middle Bolsovian by bedload-dominated fluvial red beds of the Petrovice Member, terminated by locally developed Petrovice Coal (Fig. 1). There are uncommon macrofloral remains throughout the member suggesting the persistence of relatively significant proportion of wetland taxa including arborescent lycopsids. Their diversity is, however, low (Opluštil et al. 2017). Species that continue from the Prkenný Důl-Žd'árky to the Petrovice members mostly disappear in this latter unit, whereas some new taxa typical of Asturian (e.g. Sphenophyllum emarginatum Brongniart, Annularia sphenophylloides Zenker and A. spinullosa reported as A. stellata Schlotheim) appear for the first time. Mostly extrapolated palynological data (except the Petrovice Coal) show less pronounced drop in diversity comparing to macrofloral record (Figs 4, 5) and persistence of number of miospore taxa into the Cantabrian (Fig. 4). The presence of easily identifiable Vittatina pollen of possibly peltaspermalean origin is surprising and may indicate a stronger ecological gradient in basinal lowland during middle Bolsovian times. It allowed coexistence of scattered small-scale wetlands including peat swamps and well-drained habitats colonized by the plants typical for latest Pennsylvanian and early Permian (DiMichele et al. 2008, Pfefferkorn et al. 2008, DiMichele 2014).

Overlying interval of deposition is separated from the Petrovice Member by $\sim 3$ my long hiatus and comprises upper Asturian floodplain-dominating red beds of the lower Svatoňovice Member followed by the Cantabrian Svatoňovice coal group in the Upper Svatoňovice Member (Fig. 1). The scarce macrofloral remains from the red beds are represented by calamites, tree fern foliage, pteridosperms and exceptional findings of the earliest known walchian conifer shoots (Opluštil et al. 2017). The red color of strata and a mixture of dryland and wetland taxa suggest an existence of a prominent ecological gradient and a co-existence of well- and poorly-drained habitats in basin lowland, the former being probably more extensive. This landscape contrasts with the Svatoňovice coal group in top of the Svatoňovice Member, dominated by compressions of wetland plants, mostly tree ferns, calamites and medullosalen pteridosperms and subordinate lepidodendrids and sigillarian lycopsids. Similarly to macrofloral record, also palynological data show predominance of miospores produced by marattialean tree ferns, followed by calamite and lycopsid spores (Figs 11, 12). The predominance of tree ferns and subdominant calamites over arborescent lycopsids in both types of fossil records agrees with general reorganization of wetland biome in the tropical Pangea around the Middle and Late Pennsylvanian (DiMichele \& Phillips 1996, Pfefferkorn et al. 2008, Cleal et al. 2010). Early Late Pennsylvanian wetlands were dominated by tree ferns, calamites, medullosalean pteridosperms with only small populations of arborescent lycopsids, the species composition of which differs from Duckmantian taxa (Němejc 1958, Opluštil et al. 2017).

Another interval of deposition, the Jívka Member (Fig. 1), follows the upper Cantabrian to lower Barruelian hiatus. Its major part consists of upper Barruelian coarse-grained red beds (Žaltman Arkoses) capped by the Radvanice coal group of Saberian age. The red beds provided poorly preserved plant impressions in mudstone intercalations dominated by cordaitaleans leaves, and walchian shoots, whereas in the arkoses there are rich silicified gymnosperm woods (Mencl et al. 2009, Opluštil et al. 2017). Sedimentological data and macrofloral record suggests the presence of well-drained habitats on braid plain colonised dominantly by cordaitalean or walchian conifers. However, interpolated palynological data (Fig. 4) and exceptional findings of lycopsid shoot and some sphenopsid and fern foliage suggest co-existence of poorly-drained habitats serving as refugia for wetland flora during periods of pronounced seasonality of climate. Radvanice coal group represents an interval favouring peat formation under more humid conditions. Comparing 


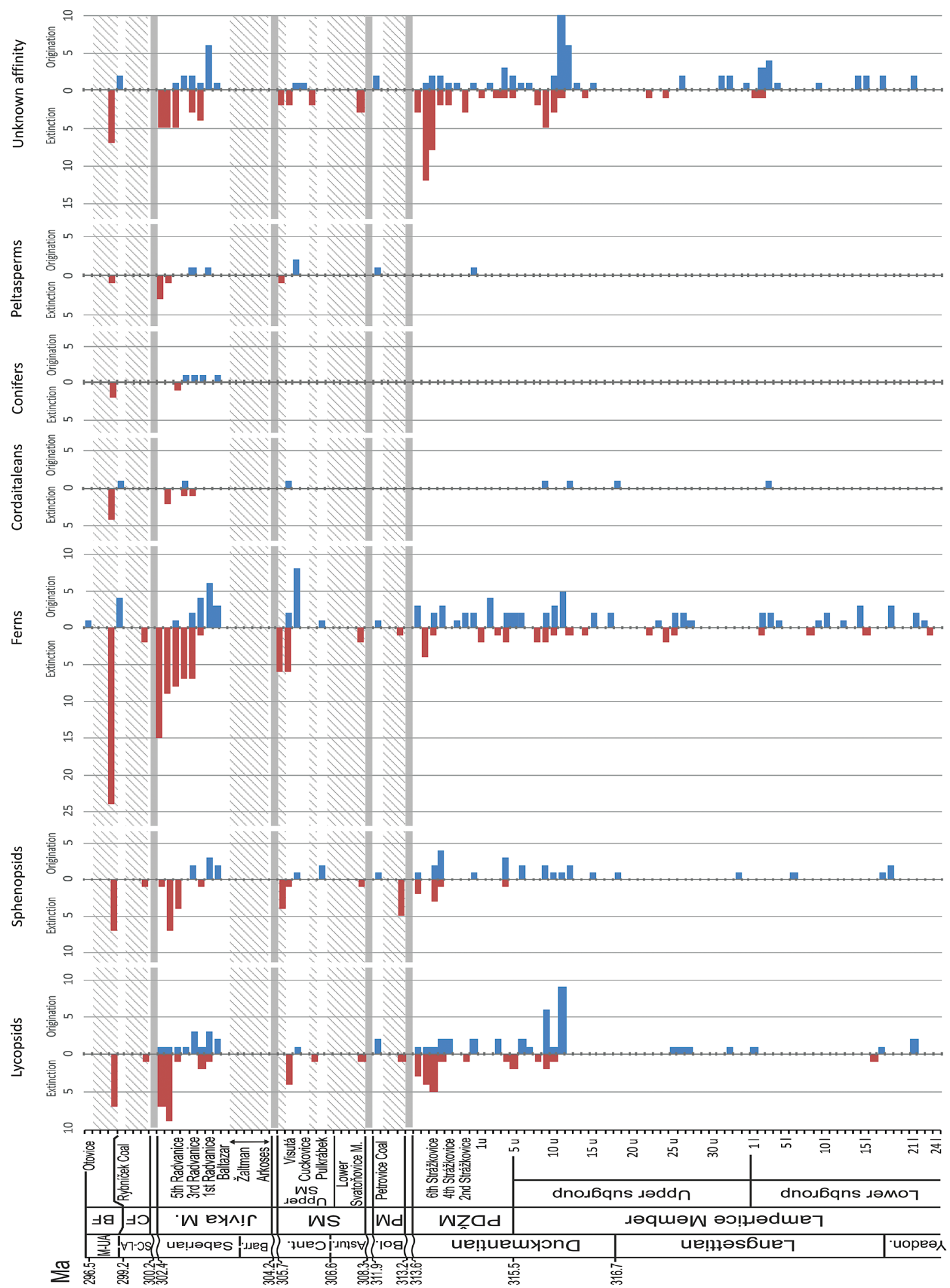

Figure 14. Origination and extinction of miospore taxa within major plant groups expressed in number of species in the Czech part of the IntraSudetic Basin. Abbreviations: Yeadon. - Yeadonian; PDŽM - Prkenný Důl-Žd'árky Member; PM - Petrovice Member; SM - Svatoňovice Member; M. - member; CF - Chvaleč Formation; BF - Broumov Formation; Bol. - Bolsovian; Astur. - Asturian; Cant. - Cantabrian; Barr. - Barruelian; Saber. - Saberian; SC-LA - Stephanian C-lower Autunian; M-UA - middle-upper Autunian. 
to earlier coal-bearing intervals, however, this is the first time when walchian conifers enter the fossil record both as pollen (electronic supplement 1; Figs 4, 12) and plant compressions in coal seams or mudstones directly associated with them (Opluštil et al. 2017). It indicates that even during formation of these relatively extensive peat swamps there were well-drained habitats colonized by dryland conifer flora in basinal lowland. In contrast, during formation of peat in pre-Saberian times, habitats in the basinal lowland of the Intra-Sudetic Basin were still dominated by extensive wetlands generally unfavourable for colonization by walchian conifers. However, during the deposition of the Asturian red beds the basinal lowland was a well-drained alluvial plain colonized by gymnosperms including conifers (Opluštil et al. 2017). The earliest palynological record of conifers in the Radvanice coal group (Saberian) coincides with the first occurrence of walchian foliage in mudstones directly associated with coal seams (Šetlík 1977, Opluštil et al. 2017), probably as a consequence of stronger ecological gradient in basinal lowland comparing to earlier peat-forming intervals. Present in palynological record are also peltaspermales and gingkoales pollens Guthoerlisporites and Wilsonites that extend diversity of dryland biome. However, it is assumed that wetland habitats still prevailed the basin being colonized dominantly by marattialean tree ferns, sphenopsids and subdominant arborescent lycopsids. The latter were represented by Sigillaria brardii Brongniart, Asolanus camptotaenia Wood and few lepidodendrid species (Němejc 1958, Opluštil et al. 2017).

Following another hiatus, deposition continued by the upper Stephanian lower Permian Chvaleč Formation, a red beds succession interrupted by two lacustrine intervals (Fig. 1). Red beds bear only rare impressions of cordaitalean and especially walchian remains (Tásler et al. 1979). However, the Vernéřovice Horizon with locally developed Rybníček Coal provided macroflora and about 60 miospore and pollen species, the former dominated by marattialen tree ferns with subordinate sphenopsid and even lycopsid miospores, mostly of the genus Lycospora (Fig. 4). Present are also pollen of cordaitalean, walchian and peltasperm seed plants. In contrast, macrofloral record provided remains of calamites and pteridosperms (Medullosales, Callystophytales and Peltaspermales) but no ferns (Šetlík in Tásler et al. 1979). We conclude that Rybníček coal swamp located along lake coast was dominated by wetland taxa, mostly ferns and sphenopsids with subordinate lycopsids including Polysporia, lepidodendrids and Sigillaria brardii. Common part of the peat swamp and clastic wetlands was also medullosalean and callistophytalean pteridosperms, not recorded in palynomorph assemblage. Drier habitats but probably still not far from the wetlands were possibly colonised by pteridosperms of peltaspermales affinity, whereas dryland habitats further away (not recorded in macroflora) were colonised dominantly by cordaitaleans and walchian conifers. This dryland biome predominated during deposition of the red beds part of the Chvaleč Formation.

The lower Permian red beds provided only very sparse and poorly preserved plant impressions dominated by walchian conifers. However, lacustrine horizons in the Olivětín Member bear relatively rich and diverse macrofloral record. In contrast, only few miospore taxa were obtained. Plant compressions suggest the existence of landscape dominated by conifers and pteridosperms (mostly peltasperms) with subordinate ferns, sphenopsids and cordaitalens (Opluštil et al. 2017). Lycopsids are represented only by Sigillaria brardii. However, the occurrence of Lycospora may indicate survival of very small populations of lepidodendrid lycopsids until Asselian times. They are, however, so far unknown in macrofloral record. This is not so unusual, in the late Autunian (= early Asselian) strata of the Autun Basin in France there also contains several Lycospora species (Châteauneuf et al. 1992).

\section{Summary}

The Intra-Sudetic Basin is a small continental basin situated along Czech-Polish border with a depositional history ranging from late Mississippian to Triassic times. Evaluation of a huge amount of previously unpublished palynological data from boreholes and coal mines provided a consistent overview on miospore and pollen diversity and stratigraphic ranges of all identified taxa from late Baskhirian to early Asselian times in a resolution of up to individual cyclothems. This, in turn, allowed the comparison of miospores and pollen ranges and diversities with recently published macrofloral record. The major results and conclusions are as follows:

(1) Palynological record is affected by the potential for preservation that varied throughout the studied interval, mainly due to shifts between more humid and drier (more seasonal) climate. These shifts controlled the groundwater table, and in turn, preservation/decomposition of plant remains and miospores and pollen. As a result, the palynological data derive from coal-bearing intervals, whereas in coal-barren red beds "data" are a mere interpolation of taxa between adjacent coal-bearing strata.

(2) Palynological samples are primarily coal and carbonaceous mudstones representing originally peat or mixed peat-clastic swamp environments, i.e. dominantly wetland flora composed of plant lineages, mainly of free-sporing plants. 


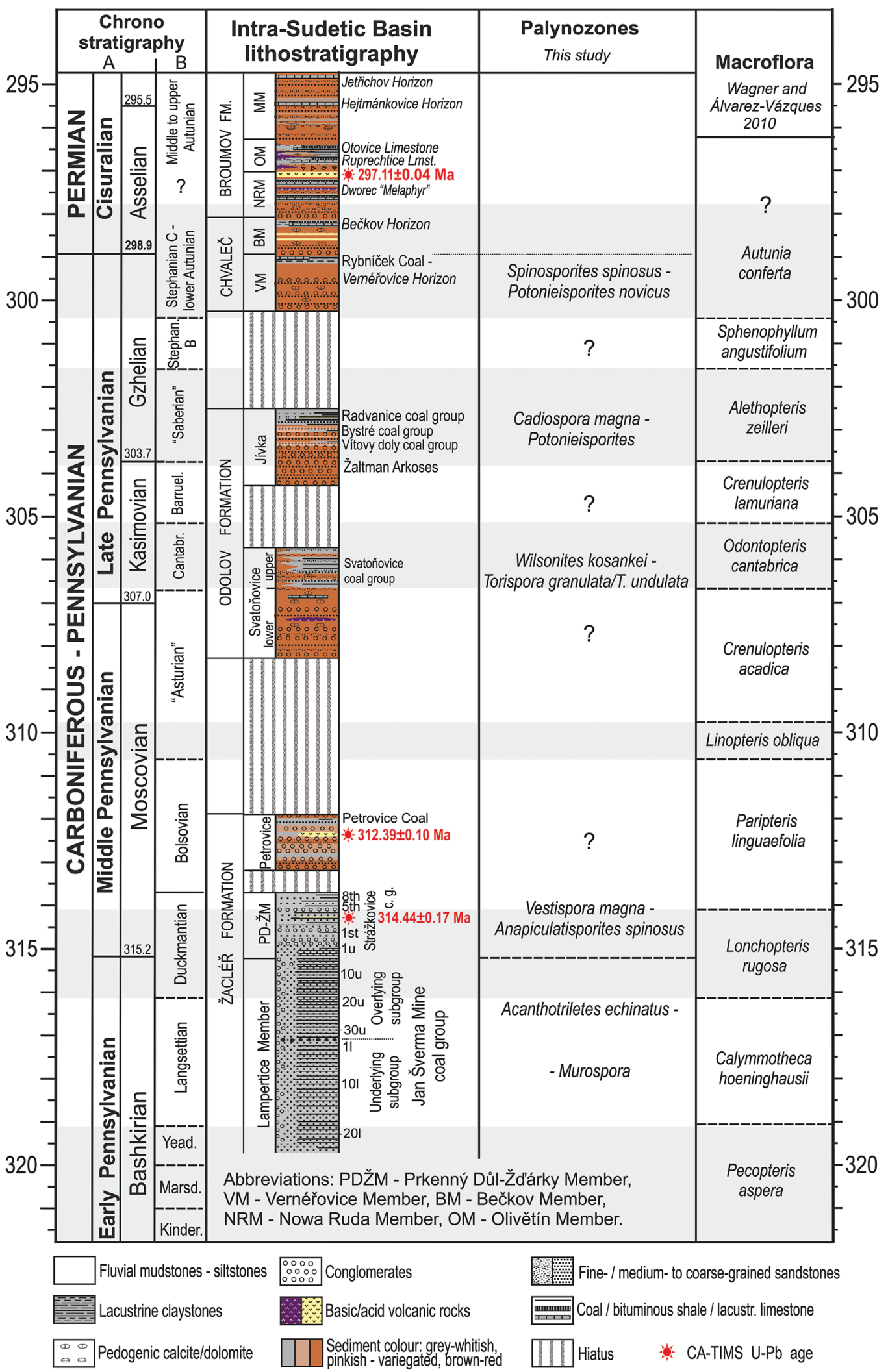

Figure 15. Palynological zones defined in this study and their comparison with macrofloral zones. Abbreviations: Kinder - Kinderscoutian; Marsd. Marsdenian; Yead. - Yeadonian; Cantabr. - Cantabrian; Barruel. - Barruelian; Stephan. - Stephanian; FM. - formation; PD-ŽM - Prkenný Důl-Žd’árky Member; VM - Vernéřovice Member; BM - Bečkov Member; NRM - Nowa Ruda Member; OM - Olivětín Member; MM - Martínkovice Member. 
(3) In all, 78 genera and 322 species have been identified. These are mostly miospores; pollen of seed plants is very rare, represented mainly by cordaitaleans, walchian conifers and rare peltaspermalean and/or cycadalean plant producers. Pollen of other pteridosperms (e.g. medullosaleans) are absent, although these plants dominate in abundance and diversity compression floras associated with coals.

(4) Five new palynozones (Fig. 15) are proposed based on first occurrences of stratigraphically important and morphologically prominent spore and pollen taxa. These taxa include Acanthotriletes echinatus, Alatisporites hexalatus Kosanke, Cirratriradites flabelliformis, Vestispora magna, Wilsonites kosankei Bharadwaj, Torispora granulata, T. undulata, Cadiospora magna, Spinosporites spinosus and genera Murospora and Potonieisporites. Each palynozone corresponds to one member; only for the Petrovice and Olivětín members it was not possible to suggest any palynozone due to very poor dispersed record with very low number of specimens.

(5) Two main trends through the basin succession can be recognised. The first is increased percentage of monolete (sphenophyllalean origin) miospores (more than $35 \mu \mathrm{m}$ ) and pollen from the late Baskhirian to early Asselian and the second is a prominent increased number (not first occurrence) of smallest (marratialean origin) monoletes (less than $35 \mu \mathrm{m}$ ) within the Jívka Member. The boundary between the Svatoňovice and Jívka members represented the most important change because dispersed spore and pollen assemblages significantly differ mainly in the appearance of coniferalean and gingkoalean pollen together with rapid abundance of marattialean miospores.

(6) Some groups of miospores and pollen increased from the Lampertice to the Jívka members, i.e. sphenopsid, marattialean, coniferalean, cordaitalean, cycadalean and unknown affinity and others have a decreasing curve, i.e. spores of lycopsid, zygopterid and botryopterid genera.

(7) The comparison of European dispersed miospore and pollen assemblages from late Baskhirian to early Asselian interval shows that the most similar are those from the Polish part of the Intra-Sudetic Basin. But this similarity is not absolute because some taxa described in the Polish part of the basin (e.g. Florinites junior Potonié \& Kremp and Radiizonates) have never been described in the Czech part and other taxa [e.g. Punctatosporites bechlinensis Kalibová and Gillespieisporites spinosus (Kosanke) Kalibová] never described in the Polish part. Other taxa (e.g. Endosporites globiformis) appear later in one part of the basin than in the second one. Such differences may be influenced by the fact that almost all samples from the Czech part are from coal seams but not all samples from the Polish part are from the coal.

(8) Comparison with contemporaneous basins in Europe also shows that massively increased percentage of smallest monoletes of genera Punctatosporites, Laevigatosporites, Latosporites, Torispora, Thymospora and Speciososporites appears in several European basins and coalfields including Polish part of the Upper Silesian Basin (Górecka 1968, 1969; Górecka \& Górecka-Nowak 1990) Zwickau-Oelsnitz (Hartkopf-Fröder 2005), Saxony and Saar-Nahe Basin in Germany (Hartkopf-Fröder 2005), UK (Smith \& Butterworth 1967), Saar-Lorraine in France (Liabeuf et al. 1967, Alpern et al. 1969, Liabeuf \& Alpern 1970, Loboziak 1971) and Portugal (Pereira 1999) and the Western Europe palynozonation (Clayton et al. 1977) earlier than in the Czech part of the Intra-Sudetic Basin. This prominent higher occurrence of smallest monoletes is recorded within the Asturian in these countries, but later in early Stephanian in the Czech part of the IntraSudetic Basin. On the other hand, e.g. assemblages from the Netherlands (Wijhe \& Bless 1974) yielded a similar character at this stratigraphic level as those from the Czech part of the Intra-Sudetic Basin.

(9) Combined palynological and previously published macrofloral data suggest alternation of dominantly wetland and dryland floras (biomes) that follow basinwide alternation of coal-bearing intervals and coal-barren red beds, driven by shifts between humid and drier seasonal climates.

(10) Yeadonian to Duckmantian represents a $\sim 6 \mathrm{Ma}$ coal-bearing interval of ecological and species stability when wetland habitats including peat swamps dominated basin lowlands. Changes in species composition between neighbouring cyclothems were mostly below 10 of all miospore and pollen taxa. Basin landscape was colonized by free-sporing plants. Arborescent lycopsids were at the maximum of their diversity and abundance. Pteridosperms and ferns were also diverse. There are no indications of the presence of dryland floras in this interval neither in miospores and pollen nor in plant compressions.

(11) Since the Bolsovian, ecological gradient increases allowing for the co-existence of poorly-drained wetland and well-drained dryland habitats in the basin even during coal-bearing intervals. The proportion of dryland habitats in coal-bearing intervals increases during late Pennsylvanian. Dryland flora is first recorded by the presence of Vittatina pollen in late Bolsovian strata. Earliest evidence of conifers is from plant impressions 
in late Asturian red beds. In the Saberian coal-bearing window conifer shoots and pollens occur in sediments directly associated with coals.

(12) Palynological data indicates possible survival of lepidodendrid lycopsids into early Asselian times, although the macrofloral remains have not been found so far.

\section{Acknowledgement}

The authors dedicate this paper to P. Valterová, who spent most of her career doing palynological analysis as a part of systematic exploration of Late Palaeozoic coal-basins in the Czech Republic between the sixties and eighties. Her data provided a base for this article and we would like to stress that without her effort this paper would not be possible to prepare. This paper was prepared with the financial support of the Grant Agency of the Czech Republic (project no. 19-06728S) and the research plan of the Institute of Geology of the Czech Academy of Sciences, v.v.i., RVO67985831. Authors thank to both reviewers, G. Lopes, University of Algarve, Portugal and G. Machado, ChronoSurveys, Almada, Portugal for helpful remarks and suggestions. A special thanks to J. Wittry, the Field Museum of Natural History, Chicago, USA for corrections of English.

\section{References}

Alpern, B., Choffé, M., Lachkar, G. \& Liabeuf, J.J. 1969. Synthèse des zonation palynologiques des bassins houillers de Lorraine et de Sarre. Revue de Micropaléontologie 11, 217-221.

Alpern, B. \& Liabeuf, J.J. 1966. Zonation palynologique du Bassin houiller Lorraine. Zeitschrift der Deutschen Gesellschaft für Geowissenschaften 117, 162-177. DOI 10.1127/zdgg/117/1966/162

Balme, B.A. 1995. Fossil in situ spores and pollen grains: an annotated catalogue. Review of Palaeobotany and Palynology 87, 81-323. DOI 10.1016/0034-6667(95)93235-X

$\mathrm{BEK}$, J. 1998. Spore populations of some plants of groups Lycophyta, Sphenophyta, Pteridophyta and Progymnospermophyta from Carboniferous limnic basins of the Czech Republic. 505 pp. Ph.D. thesis, Geological Institute of the Academy of Sciences of the Czech Republic, Prague.

BeK, J. 2008. Late Mississippian-early Pennsylvanian (Serpukhovian-Bashkirian) miospore assemblages of the Bohemian part of the Upper Silesian Basin, Czech Republic. Review of Palaeobotany and Palynology 152, 40-57. DOI 10.1016/j.revpalbo.2008.04.008

BEK, J. 2017. Paleozoic in situ spores and pollen. Lycopsida. Palaeontographica B 296(1-3), 127-161. DOI 10.1127/palb/296/2017/1

Bek, J., Drábková, J., Dašková, J. \& Libertín, M. 2008. The sub-arborescent lycopsid genus Polysporia NewBerry and its spores from the Pennsylvanian (Bolsovian-Stephanian B) continental basins of the Czech Republic. Review of Palaeobotany and Palynology 152, 176-199.

DOI 10.1016/j.revpalbo.2008.05.002

BeK, J., Libertín, M. \& DrÁBKovÁ, J. 2009. Spencerites leismanii sp. nov., a new sub-arborescent compression lycopsid and its spores from the Pennsylvanian of the Czech Republic. Review of Palaeobotany and Palynology 155, 116-132. DOI 10.1016/j.revpalbo.2007.12.007

BeK, J. \& Opluštil, S. 1998. Some lycopsid, sphenopsid and pteropsid fructifications and their miospores from the Upper Carboniferous basins of the Bohemian Massif. Palaeontographica B 248, 127-161.

BeK, J. \& Opluštil, S. 2004. Palaeoecological constraints of some Lepidostrobus cones and their parent plants from the Late Palaeozoic continental basins of the Czech Republic. Review of Palaeobotany and Palynology 131, 49-89.

Bek, J., Opluštil, S., DrÁbkovÁ, J. \& PŠeničKa, J. 2015. The sub-arborescent lycopsid Omphalophloios feistmantelii (O. Feistmantel) comb. nov. emend. from the Middle Pennsylvanian of the Czech Republic. Bulletin of Geosciences 90(1), 227-279. DOI 10.3140/bull.geosci.1505

Châteauneuf, J.J., Farjanel, G., Pacaud, G. \& Broutin, J. 1992. The Autun Permian Basin, the Autunian stratotype. Cahiers de Micropaléontologie, Nouvelle série 7(1-2), 122-139.

Cecil, C.B., DiMichele, W.A. \& Elrick, S.D. 2014. Middle and Late Pennsylvanian cyclothems, American Midcontinent: Iceage environmental changes and terrestrial biotic dynamics. Compte Rendus Geoscience 346, 159-168. DOI 10.1016/j.crte.2014.03.008

Clayton, G., Coquel, R., Doubinger, J., Gueinn, K.J., Loboziak, S., Owens, B. \& Streel, M. 1977. Carboniferous miospores of Western Europe: illustration and zonation. Mededelingen Rijks Geologische Dienst 29, 1-71.

Cleal, C.J. 2005. The Westphalian macrofloral record from the cratonic central Pennines Basin, UK. Zeitschrift der Deutschen Gesellschaft für Geowissenschaften 156, 387-410. DOI 10.1127/1860-1804/2005/0156-0387

Cleal, C.J. 2018. The Carboniferous coal swamp floras of England: a window on an ancient tropical ecosystem. Proceedings of the Geologists' Association 129, 329-351. DOI 10.1016/j.pgeola.2017.05.005

Cleal, C.J., Opluštil, S., Thomas, B.A. \& Tenchov, Y. (eds) 2010. Late Moscovian terrestrial biotas and palaeoenvironments of Variscan Euramerica. Netherlands Journal of Geosciences 88(4), 181-278. DOI 10.1017/S0016774600000846

Cleal, C.J., Uhl, D., Cascales-Miñana, B., Thomas, B.A., Bashforth, A.R., King, S.C. \& Zodrow, E.L. 2012. Plant biodiversity changes in Carboniferous tropical wetlands. Earth-Science Reviews 114, 124-155. DOI 10.1016/j.earscirev.2012.05.004

Coquel, R., Doubinger, J. \& Loboziak, S. 1976. Les microspores-guides duWestphalien à l'Autunien d'Europe occidentale. Revue de Micropaléontologie 18, 200-212.

Davydov, V.I., Crowley, J.L., Schmitz, M.D. \& Poletaev, V.I. 2010. High-precision $\mathrm{U}-\mathrm{Pb}$ zircon age calibration of the global Carboniferous timescale and Milankovitch band 
cyclicity in the Donets Basin, eastern Ukraine. Geochemistry, Geophysics, Geosystems 11(2), 1-22.

DOI 10.1029/2009GC002736

Dettmann, M.E. 1963. Upper Mesozoic microfloras from southeastern Australian Proceedings of Royal Society of Victoria. New series 77(1), 1-148.

DiMichele, W.A. 2014. Wetland-Dryland Vegetational Dynamics in the Pennsylvanian Ice Age Tropics. International Journal of Plant Sciences 175(2), 123-164. DOI 10.1086/675235

DiMichele, W.A. \& Phillips, T.L. 1996. Climate change, plant extinctions and vegetational recovery during the Middle-Late Pennsylvanian Transition: the Case of tropical peatforming environments in North America, 201-221. In HART, M.B. (ed.) Biotic Recovery from Mass Extinction Events. Geological Society London, Special Publication 102.

DOI 10.1144/GSL.SP.1996.001.01.14

DiMichele, W.A., Kerp, H., Tabor, N.J. \& Looy, C.V. 2008. The so-called 'Paleophytic-Mesophytic' transition in equatorial Pangea - multiple biomes and vegetational tracking of climate change through geological time. Palaeogeography, Palaeoclimatology, Palaeoecology 268, 152-163.

DOI 10.1016/j.palaeo.2008.06.006

Dimitrova, T.K. 2004. Microfloral biostratigraphy and vegetation change in the late Westphalian of the Dobrudzha Basin, NE Bulgaria. Geologica Balcanica 34(1-2), 21-27.

Dimitrova T.K., Cleal, C.J. \& Thomas, B.A. 2005. Palynology of late Westphalian early Stephanian coal-bearing deposits in the eastern SouthWales Coalfield. Geological Magazine 142, 809-821. DOI 10.1017/S001675680500107X

Dimitrova, T.K. \& Cleal, C.J. 2007. Palynological evidence for late Westphalian-early Stephanian vegetation change in the Dobrudzha Coalfield, NE Bulgaria. Geological Magazine 144(3), 513-524. DOI 10.1017/S0016756807003378

Dimitrova, T., Cleal, C.J. \& Thomas, B.A. 2011. Palynological evidence for Pennsylvanian extra-basinal vegetation in Atlantic Canada. Journal of Geological Society London 168, 559-569. DOI 10.1144/0016-76492010-028

Dolby, G. 1988. Palynological analysis of the No. 3 and Rodney seams, Springhill and other samples from the Cumberland Basin, Nova Scotia. 70 pp. Nova Scotia Department of Mines and Energy Report.

Dolby, G., Falcon-Lang, H.J. \& Gibling, M.R. 2011. A coniferdominated palynological assemblage from Pennsylvanian (late Moscovian) alluvial drylands in Atlantic Canada: implications for the vegetation of tropical lowlands during glacial phases. Journal of the Geological Society London 168, 571-584. DOI 10.1144/0016-76492010-061

EBLE, C.F. 2002. Palynology of late Middle Pennsylvanian coal beds in the Appalachian Basin. International Journal of Coal Geology 50, 73-88.

DOI 10.1016/S0166-5162(02)00114-3

Eble, C.F., Pierce, B.S. \& Grady, W.C. 2003. Palynology, petrography and geochemistry of the Sewickley coal bed (Monongahela Group, Late Pennsylvanian), Northern Appalachian Basin, USA. International Journal of Coal Geology 55, 187-204.

DOI 10.1016/S0166-5162(03)00110-1
Eble, C.F., Grady, W.C. \& Blake, B.M. 2013. Dunkard Group coal beds: Palynology, coal petrography and geochemistry. International Journal of Coal Geology 119, 32-40.

DOI 10.1016/j.coal.2013.07.023

ERGÖNÜL, Y. 1960. The Palynological Investigation of Carboniferous Coal Measures in the Amasra Basin. Bulletin of the Mineral Research and Exploration 55, 1-16.

Falcon-Lang, H.J. \& DiMichele, W.A. 2010. What happened to the coal forests during Pennsylvanian glacial phases? Palaios 25, 601-617. DOI 10.2110/palo.2009.p09-162r

Gastaldo, R.A. \& DemKo, T.M. 2011. Long-term hydrology controls the plant fossil record, 249-286. In Allison, P.A. \&BotTJER, D.J. (eds) Taphonomy: processes and bias through time, $2^{\text {nd }}$ edition. Topics in Geobiology 32.

DOI 10.1007/978-90-481-8643-3_7

Gastaldo, R.A., Purkyñová, E., Šimưnek, Z. \& Schmitz, M.D. 2009. Ecological persistence in the late Mississippian (Serpukhovian, Namurian A) megafloral record of the Upper Silesian Basin, Czech Republic. Palaios 24, 336-350.

DOI 10.2110/palo.2008.p08-084r

Gomankov, A. \& Meyen, S. 1986. Tatarinian flora (taxonomic composition and distribution in the Late Permian of Eurasia). 174 pp. Nauka, Moscow. [in Russian]

GóreCKA, T. 1968. Problem granicy namur-westfal w północnozachodniej części depresji śródsudeckiej. Kwartalnik Geologyczny 12(1), 51-64.

GóreCKA, T. 1969. Stratigraphy of the Biały Kamien beds in the north-western part of the Intra-Sudetic through on the ground of palynological research. Biuletin Instytutu Geologycznego 230, 167-292.

Górecka, T. \& Górecka-NowaK, A. 1979. Palynostratigraphic studies of Upper Carboniferous deposits from the IntraSudetic Basin, SW Poland. Review of Palaeobotany and Palynology 65, 287-292.

DOI 10.1016/0034-6667(90)90078-W

Górecka, T. \& Górecka-NowaK, A. 1990. Palynostratigraphic studies of Upper Carboniferous deposits from the IntraSudetic Basin, southwestern Poland. Review of Palaeobotany and Palynology 65(1-4), 287-292.

DOI 10.1016/0034-6667(90)90078-W

Grebe, H. 1972. Die Verbreitung der Miosporen in Ruhrkarbon von den Bochumer Schichten bis zu den Dorstener Schichten (Westfal A-C). Palaeontographica B 140(1-3), 27-115.

HartKopf-FröDER, C. 2005. Palynostratigrafie des Pennsyvanium in Deutschland. Courier Forschungsinstitut Senckenberg 254, 133-160.

Hoof T.B. van, Falcon-Lang, H.J., Hartkopf-Fröder, C. \& KERP, H. 2013. Conifer-dominated palynofloras in the Middle Pennsylvanian strata of the De Lutte- 6 borehole, The Netherlands: Implications for evolution, palaeoecology and biostratigraphy. Review of Palaeobotany and Palynology 188, 18-37. DOI 10.1016/j.revpalbo.2012.09.003

KAISERovÁ, M. 1960. Zpráva o palynologických výzkumech $v$ oblasti žacléřské. 16 pp. Archiv Českého geologického ústavu, Praha.

Jasper, K., Hartkopf-Fröder, C., Flajs, G. \& Littke, R. 2010. Palaeoecological evolution of Duckmantian wetlands in 
the Ruhr Basin (western Germany): A palynological and coal petrographical analysis. Review of Palaeobotany and Palynology 162, 123-145.

DOI 10.1016/j.revpalbo.2010.06.009

KмIECIK, H. 1978. Carboniferous palynostratigraphy of Polish Coals Basins. Przegład Geołogiczny 35, 247-259.

Liabeuf, J.J. \& Alpern, B. 1970. Le gisement Houiller de Decise. Etude palynologique. $6^{\text {th }}$ International Congress de Carbonifére Stratigraphie et Geologie. Compe Rendu 3, 1083-1101.

Liabeuf, J.J., Doubinger, J. \& Alpern, B. 1967. Caractêres Palynologiques des Charbons du Stéphanien de quelques Gisements Français. Revue Micropaléontologie 10(1), 3-14.

Libertín, M., Bek, J. \& DrábKová, J. 2014. Two new Carboniferous fertile sphenophylls and their spores from the Czech Republic. Acta Palaeontologica Polonica 53(4), 723-732. DOI 10.4202/app.2008.0414

Libertín, M., DašKová, J., Opluštil, S. \& Edress, N. 2009. A palaeoecological model for a vegetated early Westphalian intramontane valley (Intra-Sudetic Basin, Czech Republic), 175-203. In Bek., J. \& Kerp H. (eds) Late Palaeozoic Palaeobotany and Palynology in Central Europe: New Contributions from the Czech Republic. Review of Palaeobotany and Palynology 155(3-4).

DOI 10.1016/j.revpalbo.2008.07.002

Loboziak, S. 1971. Les micro et mégaspores de la partie occiden-tale du bassin houiller du Nord de la France. Palaeontographica B 132, 1-127.

Looy, C.V., Kerp, H., Duijnstee, I.A.P. \& DiMichele, W.A. 2014. The late Paleozoic ecological-evolutionary laboratory, a land-plant fossil record perspective. The Sedimentary Record 12(4), 4-10. DOI 10.2110/sedred.2014.4.4

McLean, D., Owens, B. \& Neves, R. 2005. Carboniferous miospore biostratigraphy of the North Sea, 13-24. In Collinson, J.D., Evans, D.J., Holiday, D.W. \& Jones, N.S. (eds) Carboniferous hydrocarbon geology: the nortern North Sea and surrounding onshore areas. Occasional Publications, Series Yorkshire Geological Society 7.

Mencl, V., Matysová, P. \& Sakala, J. 2009. Silicified woods from the Czech part of the Intra Sudetic Basin (Late Pennsylvanian, Bohemian Massif, Czech Republic): systematics, silicification and palaeoenvironment. Neues Jahrbuch für Geologische und Paläontologische Abhandlungen 252(3), 269-288. DOI 10.1127/0077-7749/2009/0252-0269

Meyen, S.V. 1987. Fundamentals in palaeobotany. 432 pp. Chapman and Hall, New York.

DOI 10.1007/978-94-009-3151-0

NĚMEJC, F. 1958. Biostratigraphical studies in the Carboniferous of the Bohemian part of the Intrasudetic Basin. Rozpravy Československé Akademie Věd, rada matematických a prírodnich věd 68(6), 1-67.

Nowak, G.J. \& Górecka-Nowak, A. 1999. Peat-forming environments of Westphalian A coal seams from the Lower Silesian Coal Basin of southwest Poland. International Journal of Coal Geology 40, 327-351.

DOI 10.1016/S0166-5162(99)00007-5

Opluštil, S., BeK, J. \& DrÁBKovÁ, J. 2009. A new bisporangiate lycopsid cone genus Thomasostrobus gen. nov. from the Late Pennsylvanian of the Intra-Sudetic Basin (Czech Republic). Bulletin of Geosciences 84(2), 283-300.

DOI 10.3140/bull.geosci.1127

Opluštil, S., LoJka, R., PšeničKa, J., Yilmaz, C. \& Yilmaz, M. 2018. Sedimentology and stratigraphy of the Amasra coalfield (Pennsylvanian), NW Turkey - New insight from a $1 \mathrm{~km}$ thick section. International Journal of Coal Geology 195, 317-346. DOI 10.1016/j.coal.2018.06.013

Opluštil, S., Lojka, R., Rosenau, N., Strnad, L. \& Kędzior, A. 2019. Climatically-driven cyclicity and peat formation in fluvial setting of the Moscovian - Early Kasimovian Cracow Sandstone Series, Upper Silesia (Poland). International Journal of Coal Geology 212, art. 103234.

DOI 10.1016/j.coal.2019.103234

Opluštil, S., Schmitz, M., Kachlík, V. \& Štamberg, S. 2016 a. Re-assessment of lithostratigraphy, biostratigraphy, and volcanic activity of the Late Paleozoic Intra-Sudetic, Krkonoše-piedmont and Mnichovo Hradiště basins (Czech Republic) based on new U-Pb CA-ID-TIMS ages. Bulletin of Geosciences 91(2), 399-432. DOI 10.3140/bull.geosci.1603

Opluštil, S., Schmitz, M., Cleal, C.J. \& Martínek, K. 2016 b. A review of the Middle-Late Pennsylvanian west European regional substages and floral biozones, and their correlation to the Global Time Scale based on new U-Pb ages. Earth Science Review 154, 301-335.

DOI 10.1016/j.earscirev.2016.01.004

Opluštil, S., ŠimưneK, Z., PŠEničKa, J., BeK, J. \& Libertín, M. 2017. A 25 million year macrofloral record (CarboniferousPermian) in the Czech part of the Intra-Sudetic Basin; biostratigraphy, plant diversity and vegetation patterns. Review of Palaeobotany and Palynology 244, 241-307.

DOI 10.1016/j.revpalbo.2016.11.011

Opluštil, S., ŠimưneK, Z., Zajíc, J. \& Mencl, V. 2013. Climatic and biotic changes around the Carboniferous/Permian boundary recorded in the continental basins of the Czech Republic. International Journal of Coal Geology 119, 114-151. DOI 10.1016/j.coal.2013.07.014

Peppers, R.A. 1996. Carboniferous chronostratigraphic boundaries in the Illinois and other coal seams. Geological Society of America Memoir 118, 1-111.

PeŠEK, J. 2004. Late Palaeozoic limnic basis and coal deposits of the Czech Republic. Folia Musei Rerum Naturalium Bohemiae Occidentalis, Geologica 1, 1-188.

Pešek, J., Holub, V., Jaroš, J., Malý, L., Martínek, K., Prouza, V., Spudil, J. \& TÁsler, R. 2001. Geologie a ložiska svrchnopaleozoických limnických pánvi České republiky. 243 pp. Český geologický ústav, Praha.

Pereira, Z. 1999. Palynostratigraphy of the South-west Portugal, South Portuguese Zone. Comunicações do Instituto Geológico e Mineiro 96, 25-58.

Pfefferkorn, H.W. \& Thomson, M.C. 1982. Changes in dominance patterns in Upper Carboniferous plant-fossil assemblages. Geology 10(12), 641-644.

DOI 10.1130/0091-7613(1982)10<641:CIDPIU>2.0.CO;2

Pfefferkorn, H.W., Gastaldo, R.A., Dimichele, W.A. \& Phillips, T.L. 2008. Pennsylvanian tropical floras from the 
United States as a record of changing climate, 305-316. In Fielding, C.R., Frank, T.D. \& Isbell, J.L. (eds) Resolving the Late Paleozoic Ice Age in time and space. Geological Society of America Special Paper 441.

DOI 10.1130/2008.2441(21)

Phillips, T.L., Peppers, R.A. \& DiMichele, W.A. 1985. Stratigraphic and interregional changes in Pennsylvanian coal swamp vegetation: environmental inferences. International Journal of Coal Geology 5, 43-109.

DOI 10.1016/0166-5162(85)90010-2

Poort, R.J. \& Kerp, H. 1990. Aspects of Permian palaeobotany and palynology. XI. On the recognition of true peltasperms in the Upper Permian of Western and Central Europe and a reclassification of species formerly included in Peltaspermum Harris. Review of Palaeobotany and Palynology 63, 197-225. DOI 10.1016/0034-6667(90)90100-W

Potonié, R. \& KRemp, G. 1954. Die Gattungen der Palaözoischen Sporae dispersae und ihre Stratigraphie. Geologische Jahrbuch 69, 111-193.

Potonié, R. \& Kremp, G. 1955. Die Sporae dispersae des Ruhrkarbons ihre Morphographie und Stratigraphie mit Ausblicken auf Arten anderer Gebiete und Zeitabschnitte. Teil I. Palaeontographica B 98, 1-136.

Roscher, M. \& Schneider, J.W. 2006. Permo-Carboniferous climate: Early Pennsylvanian to Late Permian climate development of central Europe in a regional and global context. Geological Society London, Special Publication 265, 95-136. DOI 10.1144/GSL.SP.2006.265.01.05

Schneider, J.W., Lucas, S.G., Scholze, F., Voigt, S., Marchetti, L., Klein, H., Opluštil, S., Werneburg, R., Golubev, V.K., Barrick, J.E., Nemyrovska, T., Ronchi, A., Day, M.O., Silantiev, V.V., Rössler, R., Saber, H., Linnemann, U., Zharinova, V. \& Shen, S.Z. 2020. Late Paleozoic-early Mesozoic continental biostratigraphy - links to the Standard Global Chronostratigraphic Scale. Palaeoword 29, 186-238. DOI 10.1016/j.palwor.2019.09.001

ŠEtLí, J. 1977. Results on recent investigation on the Carboniferous flora of Bohemia, 315-340. In Holub, V. \& Wagner, R.H. (eds) Symposium on Carboniferous Stratigraphy. Czechoslovakian Geological Survey (Prague).

ŠIMŮNeK, Z. 2007. New classification of the genus Cordaites from the Carboniferous and Permian of the Bohemian Massif, based on cuticle micromorphology. Sbornik Národniho musea, ̌̌ada B, prírodní vědy 62(3-4), 97-210.

ŠImŮneK, Z. \& Libertín, M. 2006. Cordaites schatzlarensis sp. nov. and Samaropsis newberryi (Andrews) Seward from the Westphalian (Carboniferous) of the Žaclér area (Czech Republic). Review of Palaeobotany and Palynology 138, 43-62. DOI 10.1016/j.revpalbo.2005.10.001

Smith, A.H.V. \& Butterworth, M.A. 1967. Miospores in the coal seams of the Carboniferous of Great Britain. Special Papers in Palaeontology 1, 1-324.

TÁsler, R., Čadková, Z., Dvořík, J., Fediuk, F., ChaloupskÝ, J., Jetel, J., Kaiserová-Kalibová, M., Prouza, M., SchovÁNKovÁ-HrdličKovÁ, D., StŘEdA, J. \& Šetlík, J. 1979. Geology of the Bohemian part of the Intra-Sudetic Basin. 269 pp. Academia, Praha.
Valterová, P. 1965. Palynologický rozbor vzorků z Dolu Nejedlý. 6 pp. Geofond, Praha.

Valterová, P. 1967a. Palynologický posudek k lokalitě VSD Důl Zdeněk Nejedlý. 16 pp. Geofond, Praha.

VAlterová, P. 1967b. Závěrečná zpráva o palynologickém výzkumu radvanických slojí kúkolu Stachanov. 24 pp. Geofond, Praha.

VALTEROVÁ, P. 1967c. Zpráva a palynologickém výzkumu radvanických slojí ve vnitrosudetské pánvi. Zprávy o geologických výzkumech v roce 1966, 165-166.

Valterová, P. 1967d. Palynologický posudek $k$ vrtu Vd-3 (Vernérovice). 5 pp. Geofond, Praha.

Valterová, P. 1967e. Palynologický posudek $k$ vrtu Re-5 (Radvanice). 4 pp. Geofond, Praha.

Valterová, P. 1967f. Palynologický posudek $k$ vrtu Re-6 (Radvanice). 5 pp. Geofond, Praha.

Valterová, P. 1967g. Palynologický posudek k vrtu Hd-1 (Hodkovice). 6 pp. Geofond, Praha.

Valterová, P. 1967h. Palynologický posudek k vrtu Ja-1 (Janovice). 5 pp. Geofond, Praha.

Valterová, P. 1967i. Palynologický posudek k vrtu V-3 (Jivka). 7 pp. Geofond, Praha.

VAlterovÁ, P. 1968a. Palynologický posudek k lokalitě Vnitrosudetská deprese II. č. ú. 5120201052.28 pp. Geofond, Praha.

VAlterová P. 1968b. Palynologický posudek k vrtu Š-2 (ŠvermaLampertice). 6 pp. Geofond, Praha.

Valterová, P. 1968c. Palynologický posudek $k$ vrtu $\breve{S}-10$ (Šverma-Lampertice). 10 pp. Geofond, Praha.

ValterovÁ, P. 1968d. Palynologický posudek k vrtu Lh-2 (Lhota). 8 pp. Geofond, Praha.

Valterová, P. 1969a. Palynologická zpráva k úkolu ŠvermaLampertice. 27 pp. Geofond, Praha.

Valterová, P. 1969b. Palynologický posudek k vrtu ̌́-1 (ŠvermaLampertice). 8 pp. Geofond, Praha.

Valterová, P. 1969c. Palynologický posudek $k$ vrtu $\check{S}-12$ (Šverma-Lampertice). 7 pp. Geofond, Praha.

Valterová, P. 1969d. Palynologický posudek $k$ vrtu $\check{S}-15$ (Šverma-Lampertice). 5 pp. Geofond, Praha.

Valterová, P. 1970. Palynologický posudek k úkolu Bečkovložisková studie. 16 pp. Geofond, Praha.

ValterovÁ, P. 1972. Palynologicko-stratigrafický výzkum českého kř́dla vnitrosudetské pánve. 38 pp. Geofond, Praha.

VAlterová, P. 1974. Palynologicko-stratigrafická zpráva k úkolu Šverma-Lampertice. 29 pp. Geofond, Praha.

Valterová, P. 1976. Palynologicko-stratigrafický posudek k úkolu Bohdašín-Velké Svatoňovice. 36 pp. Geofond, Praha.

Valterová, P. 1977a. Palynologicko-stratigrafické zhodnoceni radvanických slojí. 28 pp. Geofond, Praha.

Valterová, P. 1977b. Palynologické zhodnocení vzorků z Dolu Zdeněk Nejedlý. 18 pp. Geofond, Praha.

VAlterová, P. 1978. Stratigrafické zhodnocení rostlinných mikrofosilii ve vrtu Š-9 (Šverma). Součást závěrečné zprávy úkolu Šverma-Lampertice-kotlina. 8 pp. Geofond, Praha.

Valterová, P. 1979a. Palynologické zhodnocení vrtu Š-11 (Šverma). 6 pp. Geofond, Praha.

Valterová, P. 1979b. Stratigrafické zhodnocení vrtu Š-13 (Šverma). 8 pp. Geofond, Praha. 
VALTEROVÁ, P. 1979c. Stratigrafické zhodnocení rostlinných mikrofosilii ve vrtu Š-14 (Šverma). 9 pp. Geofond, Praha.

VAlterovÁ, P. 1979d. Stratigrafické zhodnoceni rostlinných mikrofosilii z uhelného sousloji Dolu Jan Šverma v Lamperticich. 28 pp. Geofond, Praha.

Valterová, P. 1979e. Přehled palynologických výzkumů ve vnitrosudetské pánvi. 86 pp. Kandidátské minimum. Př́rodovědecká fakulta UK, Praha.

VAlterovÁ, P. 1979f. Paleopalynologicko-stratigrafický výzkum českého krídla vnitrosudetské pánve. 127 pp. thesis, Geoindustria, Praha.

Valterová, P. 1979g. Stratigrafické zhodnocení vrtu Š-14 (Šverma). 8 pp. Geofond, Praha.

VAlterová, P. 1979h. Dodatek ke stratigrafickému zhodnoceni rostlinných mikrofosilii z uhelného sousloji Dolu Jan Šverma $v$ Lamperticich. 18 pp. Geofond, Praha.

Valterová, P. 1980a. Palynologické zhodnocení vrtu Re-8 (Radvanice). 8 pp. Geofond, Praha.

Valterová, P. 1980b. Palynologické zhodnoceni vrtu Re-7 (Radvanice). 10 pp. Geofond, Praha.

Valterová, P. 1980c. Palynologické zhodnoceni vrtu Ja-3 (Janovice). 9 pp. Geofond, Praha.

Valterová, P. 1980d. Palynologické zhodnoceni vrtu č. 781. 5 pp. Geofond, Praha.

Valterová, P. 1980e. Palynologické zhodnocení vrtu č. 782. 6 pp. Geofond, Praha.

Valterová, P. 1981a. Palynologický posudek $k$ vrtu Bh-2 (Bohdašin). 6 pp. Geofond, Praha.

Valterová, P. 1981b. Palynologický posudek k vrtu By-3 (Bystré). 7 pp. Geofond, Praha.

Valterová, P., 1981c. Palynologický posudek $k$ vrtu By-4 (Bystré). 5 pp. Geofond, Praha.

Valterová, P. 1982a. Palynologický posudek k vrtu Chv-4 (Chvaleč). 8 pp. Geofond, Praha.

Valterová, P. 1982b. Palynologický posudek k vrtu Chv-2 (Chvaleč). 7 pp. Geofond, Praha.

Valterová P. 1982c. Palynologický posudek k vrtu Hd-2 (Hodkovice). 6 pp. Geofond, Praha.

Valterová, P. 1982d. Palynologický posudek k vrtu Chv-3 (Chvaleč).7 pp. Geofond, Praha.

Valterová, P. 1982e. Palynologický posudek $k$ vrtu By-5 (Bystré). 8 pp. Geofond, Praha.

Valterová, P. 1984a. Palynologický posudek $k$ vrtu By-7 (Bystré). 9 pp. Geofond, Praha.

Valterová, P. 1984b. Palynologický posudek k vrtu Bh-3 (Bohdašin).6 pp. Geofond, Praha.

Valterová, P. 1986a. Palynologický posudek k vrtu Bh-8 (Bohdašín). 7 pp. Geofond, Praha.

Valterová, P. 1986b. Palynologický posudek k vrtu Rt-8 (Rtyně). 10 pp. Geofond, Praha.

Valterová, P. 1986c. Palynologický posudek k vrtu Rt-9 (Rtyně). 9 pp. Geofond, Praha.
Valterová, P. 1986d. Palynologický posudek k vrtu Rt-11 (Rtyně). 8 pp. Geofond, Praha.

Valterová, P. 1986e. Palynologický posudek $k$ vrtu Rt-12 (Rtyně). 11 pp. Geofond, Praha.

Valterová, P. 1986f. Palynologický posudek $k$ vrtu Bh-7 (Bohdašin). 10 pp. Geofond, Praha.

Valterová, P. 1986g. Palynologický posudek k vrtu Rt-10 (Rtyně). 8 pp. Geofond, Praha.

Valterová, P. 1986h. Palynologický posudek k vrtu By-6 (Bystré). 9 pp. Geofond, Praha.

Valterová, P. 1986i. Palynologický posudek $k$ vrtu Rt-13 (Rtyně). 9 pp. Geofond, Praha.

Valterová, P. 1986j. Palynologický posudek $k$ vrtu Bh-5 (Bohdašin). 10 pp. Geofond, Praha.

Valterová, P. 1986k. Palynologický posudek $k$ vrtu Bh-6 (Bohdašín). 7 pp. Geofond, Praha.

Valterová, P. 19861. Palynologický posudek $k$ vrtu By-8 (Bystré). 11 pp. Geofond, Praha.

Valterová, P. $1986 \mathrm{~m}$. Palynologický posudek $k$ vrtu By-9 (Bystré). 10 pp. Geofond, Praha.

Valterová, P. 1986n. Palynologický posudek k vrtu By-10 (Bystré). 9 pp. Geofond, Praha.

Wagner, R.H. 1984. Megafloral Zones of the Carboniferous. Compte rendu 9e Congrès International de Stratigraphie et de Géologie du Carbonifère (Washington, 1979) 2, 109-134.

Wagner, R.H. \& Álvarez-VÁzquez, C. 2010. The Carboniferous floras of the Iberian Peninsula: a synthesis with geological connotations. Review of Palaeobotany and Palynology 162, 239-324. DOI 10.1016/j.revpalbo.2010.06.005

Wijhe, D.H. \& Bless, M.J.M. 1974. The Westphalian of the Netherlands with special reference to miospore assemblages. Geologische Mijnbow 53, 295-328.

Willard, D.A. 1993. Vegetational patterns in the Springfield Coal (Middle Pennsylvanian, Illinois Basin): Comparison of miospore and coal-ball records. Geological Society of America Special Paper 286, 139-152.

DOI 10.1130/SPE286-p139

Willard, D.A. \& Phillips, T.L. 1993. Paleobotany and palynology of the Bristol Hill Coal Member (Bonnd Formation) and Friendsville Coal Member (Mattoon Formation) of the Illinois Basin (Upper Pennsylvanian). Palaios 8, 574-586. DOI $10.2307 / 3515033$

Willard, D.A., Phillips, T.L., Lesnikowska, A.D. \& DiMichele, W.A. 2007. Paleoecology of the Late Pennsylvanian-age Calhoun coal bed and implications for long-term dynamics of wetland ecosystems. International Journal of Coal Geology 69, 21-54. DOI 10.1016/j.coal.2006.03.011

Zerndt, J. 1937. Megaspory z westfalu i stefanu w Czechach. Megasporen aus dem Westfal und Stefan in Böhmen. Bulletin International de l'Académie polonaise des Sciences et des Lettres, 9-10A, 583-599. 


\section{Appendix}

Alphabetical list of dispersed miospore and pollen taxa recorded in the CPISB with their maximum (max.) and average (ø) percentage. Abbreviations: L - occurrence at the Lampertice Member; PZ - Prkenný Důl-Žd’árky Member; P - Petrovice Mamber; S - Svatoňovice Member; J - Jívka Member; V - Vernéřovice Member; O - Olivětín Member. Thick letters mean where the taxon is the most abundant.

Acanthotriletes acerosus Naumova, 1937. L.

Acanthotriletes echinatus (Knox) Potonié \& Kremp, 1954. L. ø 4\% max. 15\% - 24 ${ }^{\text {th }}$ upper Sub-Group of the Lampertice Coal Seam. Acanthotriletes falcatus (Knox) Potonié \& Kremp, 1954. L. ø 0.2\%.

Acanthotriletes microspinosus (Ibrahim) Potonié \& Kremp, 1954. L.

Acanthotriletes spp. L, PZ, P, S, J, V, O.ø 4\%.

Acanthotriletes triquetrus Smith \& Butterworth, 1967. PZ. ø 3\%; max. 8\% - $5^{\text {th }}$ Žd'árky Coal Seam.

Ahrensisporites angulatus (Kosanke) Dybová \& Jachowicz, 1957. L, PZ, P, S, J, O. ø 5.3\%; max. 15\% - base of PZ. Ahrensisporites guerickei (Horst) Potonié \& Kremp, 1954. L, PZ, P, S.

Ahrensisporites minutus Alpern, 1959. L, PZ, P, S.

Ahrensisporites spp. L, PZ, P, S, J, O.

Alatisporites hexalatus Kosanke, 1950. PZ.

Alatisporites pustulatus Ibrahim, 1933. L.

Alatisporites spp. L, PZ, P, S.

Alatisporites trialatus Kosanke, 1950. L.

Anapiculatisporites cf. spinosus (Kosanke) Potonié \& Kremp, 1955. L, PZ.

Anapiculatisporites minor (Butterworth \& Williams) Smith \& Butterworth, 1967. L, PZ, P, S, J. ø 2.5\%.

Anapiculatisporites spinosus (Kosanke) Potonié \& Kremp, 1955. PZ. ø 1.5\%.

Anapiculatisporites spp. L, PZ, P, S, J. ø $0.5 \%$.

Anaplanisporites globosus (Butterworth \& Williams) Smith \& Butterworth, 1967. L. ø 1.5\%.

Angulisporites splendidus Bharadwaj, 1957. J, V. ø 2.9\%, max. 5\% - Radvanice coal seams.

Apiculatasporites spinulistratus (Loose) Ibrahim, 1933. L, PZ, P, S, J. ø 4.2\%; max. 17\% - Petrovice Coal Seam.

Apiculatasporites spp. L. ø 5\%, max. 10\% 9'h underlying coal seam.

Apiculatisporites abditus (Loose) Potonié \& Kremp, 1955. PZ. ø 2\%.

Apiculatisporites aculeatus (Ibrahim) Smith \& Butterworth, 1967. L.

Apiculatisporites baccatus Hoffmeister, Staplin \& Malloy, 1955. V.

Apiculatisporites baccatus var. trebechovensis Kalibová, 1974. V.

Apiculatisporites conatus Kalibová, 1974. J. ø 4.1\%.

Apiculatisporites latigranifer (Loose) Potonié \& Kremp, 1955. PZ, P, S, J. ø 2\% (only two records).

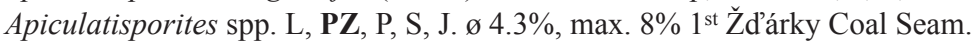

Aumancisporites spp. V.

Aumancisporites striatus Alpern, 1959. J. ø 1\% (one record).

Bellispores nitidus (Horst) Sullivan, 1964. L, PZ. ø 7.4\%; max. 22\% - Lampertice coal seams.

Bellispores spp. L, PZ. ø 2.3\%; max. 10\% - Lampertice coal seams.

B. radiatus Dybová \& Jachowicz, 1957. L, PZ.

Cadiospora spp. J, V.

Cadiospora bohemica Boháčová, 1962. J.

Cadiospora magna f. maior Kalibová-Kaiserová, 1972. J.

Cadiospora magna f. minor Kalibová-Kaiserová, 1972. J.

Cadiospora magna f. plicata Kalibová-Kaiserová, 1972. J.

Cadiospora magna Kosanke, 1950. J, V.

Cadiospora sphaera Butterworth \& Williams, 1958. J.

Calamospora breviradiata Kosanke, 1950. S, J.

Calamospora cf. laevigata Schopf, Wilson \& Bentall, 1944. J.

Calamospora hartungiana (Schopf) Schopf, Wilson \& Bentall, 1944. J.

Calamospora laevigata (Ibrahim) Schopf, Wilson \& Bentall, 1944. L, PZ.

Calamospora liquida Kosanke, 1950. L, PZ, P, S, J.

Calamospora microrugosa (Ibrahim) Schopf, Wilson \& Bentall, 1944. L, PZ, P, S, J.

Calamospora minuta Bharadwaj, 1958. PZ.

Calamospora mutabilis (Loose) Schopf, Wilson \& Bentall, 1944. L, PZ, P, S, J.

Calamospora pallida (Loose) Schopf, Wilson \& Bentall, 1944. L, PZ, P, S, J.

Calamospora pedata Kosanke, 1950. L, PZ, S, J, V. 
Calamospora perrugosa (Loose) Schopf, Wilson \& Bentall, 1944. L, PZ.

Calamospora saariana Bharadwaj, 1957. J.

Calamospora spp. L, PZ, P, S, J, V.

Calamospora straminea Wilson \& Kosanke, 1950. PZ, P, S, J, V.

Camptotriletes bucculentus (Loose) Potonié \& Kremp, 1955. L, PZ.

Camptotriletes juglandilis Horst, 1955. L.

Cingulizonates loricatus (Loose) Butterworth \& Williams, 1958. L.

Cingulizonates radiatus Dybová \& Jachowicz, 1957. L.

Cingulizonates spp. L, PZ. ø 3.8\%; max. 10\% - Lampertice coal seams.

Cingulizonates tuberosus Dybová \& Jachowicz, 1957. PZ.

Cirratriradites annulatus Kosanke \& Brokaw in Kosanke, 1950. S.

Cirratriradites flabelliformis Wilson \& Kosanke, 1944. S.

Cirratriradites rarus (Ibrahim) Schopf, Wilson \& Bentall, 1944. L. Only one occurrence; 17\% at the upper Lampertice Coal Seam.

Cirratriradites saturni (Ibrahim) Schopf, Wilson \& Bentall, 1944. L, PZ, P, S. ø 4.2\%; max. 10\% - $11^{\text {th }}$ overlying coal seam.

Cirratriradites spp. L, PZ. ø 2\%, max. 3\% PZ.

Converrucosisporites armatus (Dybová \& Jachowicz) Smith \& Butterworth, 1967. L. ø 2\% (only two records).

Converrucosisporites spp. L, PZ, P, S, J, O. ø 5\%; max. 35\% - $9^{\text {th }}$ underlying seam and $29 \%-16^{\text {th }}$ underlying seam.

Convolutispora florida Hoffmeister, Staplin \& Malloy, 1955. L.

Convolutispora jugosa Smith \& Butterworth, 1967. PZ. ø 0.5\%.

Convolutispora spp. L, PZ, P, S, J, V.ø $2 \%$; max. $5 \%-25^{\text {th }}$ and $2^{\text {nd }}$ overlying coal seams.

Convolutispora tessellata Hoffmeister, Staplin \& Malloy, 1955. L. ø 3\% (only two records).

Convolutispora varicosa Butterworth \&Williams, 1958. L, ø 1\% (only one record).

Crassispora kosankei (Potonié \& Kremp) Bharadwaj, 1957. L, PZ, P, S, J. ø 2\%.

Crassispora maculosa (Knox) Sullivan, 1964. L. ø 1\% (only one record).

Crassispora ovalis Bharadwaj, 1957. J.

Crassispora plicata Peppers, 1970. J. ø 2.5\%; max. 6\% - Radvanice coal seams.

Crassispora spp. PZ, P, S, J. ø 3\%; max. - 11\% Radvanice coal seams.

Cristatisporites indignabundus (Loose) Potonié \& Kremp, 1955. PZ. ø 26\%; max. 30\% $-5^{\text {th }}$ overlying coal seam.

Cristatisporites saarensis Bharadwaj, 1957. P.

Cristatisporites spp. L, PZ, ø 7.5\%; max. 24\% - base of PZ.

Cristatisporites solaris (Balme) Butterworth et al., 1964. L, PZ. ø 5.5\%; max. 10\% $-5^{\text {th }}$ overlying seam.

Cyclogranisporites aureus (Loose) Potonié \& Kremp, 1955. L, PZ, P, S, J. ø 4.5\%; max. 23\% - Radvanice coal seams.

Cyclogranisporites densus Bharadwaj, 1957. J, V. ø 4.2\%; max. 16\% - Radvanice coal seams.

Cyclogranisporites jelenicensis Kalibová, 1978. PZ, S, J, V. ø 6.5\%; max. 26\% - Radvanice coal seams.

Cyclogranisporites leopoldii (Kremp) Potonié \& Kremp, 1955. L, PZ, S.

Cyclogranisporites minutus Bharadwaj, 1957. L, PZ, S, J.

Cyclogranisporites orbicularis (Kosanke) Potonié \& Kremp, 1955. L, PZ, S, J. ø 5\%; max. 30\% - Radvanice coal seams.

Cyclogranisporites pergranulus Alpern, 1959. J. ø 1\% (one record).

Cyclogranisporites pressoides Potonié \& Kremp, 1955. L.

Cyclogranisporites spp. L, PZ, P, S. ø 4.6\%; max. 16\% at S.

Densosporites anulatus (Loose) Schopf, Wilson \& Bentall, 1944. L, PZ, P. ø 5\%; max. 13\% - base of P.

Densosporites lobatus Kosanke, 1950. L, PZ.

Densosporites sphaerotriangularis Kosanke, 1950. P, S. ø 8\%; max. 14\% - base of S.

Densosporites spp. L, PZ, P, S, J. ø 20\%; max. 100\% - 3 $3^{\text {rd }}$ Žd'árky Coal Seam, 97\% - $1^{\text {st }}$ Žd'árky Coal Seam, $78 \%-2^{\text {nd }}$ Žd'árky Coal Seam.

Densosporites triangularis Kosanke, 1950. L.

Densosporites verrucosus Dybová \& Jachowicz, 1957. L, PZ.

Dictyotriletes bireticulatus (Ibrahim) Potonié \& Kremp, 1955. L, PZ. ø 4.4\%; max 8\% - $6^{\text {th }}$ Žd'árky Coal Seam.

Dictyotriletes densoreticulatus Potonié \& Kremp, 1955. L, PZ. ø 5\%; max. 10\% - $2^{\text {nd }}$ overlying coal seam.

Dictyotriletes falsus Potonié \& Kremp, 1955. PZ. ø 1\% (only one record).

Dictyotriletes muricatus Kosanke, 1950. PZ, P, S, J. ø 2\%; max. 4\% - 5

Dictyotriletes spp. L, PZ, P, S, J. ø 3.5\%; max. 30\% - Radvanice coal seams.

Dictyotriletes triangulatus Dybová \& Jachowicz, 1957. L, PZ, P, S, J.

Disaccites spp. J. ø $0.1 \%$ (only one record).

Endosporites formosus Kosanke, 1950 PZ, P, S, J, V. ø 7.5\%; max. 43\% - Radvanice coal seams.

Endosporites globiformis (Ibrahim) Schopf, Wilson \& Bentall, 1944. J, V. ø 2\%; max. 4\% - Radvanice coal seams.

Endosporites grandisaccatus Kalibová, 1978. J. ø 0.5\% (only one record).

Endosporites ornatus Wilson \& Coe, 1940. L, PZ, P, S, J. ø 7\%; max. 25\% - lower part of S. 
Endosporites spp. PZ, P, S. ø $1.8 \%$; max. $5 \%$.

Endosporites zonalis Loose in Potonié, Ibrahim \& Loose, 1932. L, PZ, ø 5\%; max. 33\% - PZ.

Euryzonotriletes spp. L.

Florinites antiquus Schopf in Schopf, Wilson \& Bentall, 1944. L, PZ, P, S, J. ø 2.5\%; max. 7\% - Baltazar Coal Seam.

Florinites mediapudens (Loose) Potonié \& Kremp, 1955. L, PZ, P, S, J. ø 4.2\%; max. 12\% - Main Svatoňovice Coal Seam.

Florinites millotii Butterworth \& Williams, 1958. PZ, P, S, J.

Florinites minutus Bharadwaj, 1958. S, J. ø 3.5\%; max. 5\% - "Visutá" Coal Seam.

Florinites piérarti Kalibová, 1964. V.

Florinites pumicosus (Ibrahim) Schopf, Wilson \& Bentall, 1944. L, PZ, P, S, J, V. ø 5\% (only two measured records)

Florinites similis Kosanke, 1950. J, V.

Florinites spp. L, PZ, P, S, J, V. ø 3.9\%; max. 21\% - Pulkrábek Coal Seam.

Foveosporites spp. L. ø 1\% (only two records).

Gillespieisporites discoideus (Kosanke) Kalibová, 1989. J. ø 3.2\%; max. 10\% - Radvanice coal seams.

Gillespieisporites spinosus (Kosanke) Kalibová, 1989. J.

Gillespieisporites spp. J., O. ø 2.6\%; max. 29\% - Baltazar Coal Seam.

Granulatisporites granulatus Ibrahim, 1933. L, PZ. ø 5.5\%; max. 47\% - $9^{\text {th }}$ overlying Coal Seam.

Granulatisporites gulaferus Potonié \& Kremp, 1955. L, PZ, P, S. ø 4.5\%; max. 25\% - lower part of S.

Granulatisporites microgranifer Ibrahim, 1933. L, PZ. ø $3.6 \%$; max. 13\% - $12^{\text {th }}$ overlying coal seam.

Granulatisporites minutus Potonié \& Kremp, 1955. L, PZ, P, S, J. ø 8\%; max. 40\% - Štrambach Coal Horizon.

Granulatisporites parvus (Ibrahim) Potonié \& Kremp, 1955. L, PZ, P. ø 3\%; max. 5\% - Petrovice Coal Seam.

Granulatisporites piroformis (Loose) Potonié, Ibrahim \& Loose, 1932. L, PZ, P, S, J. ø 4.5\%; max. 15\% - $17^{\text {th }}$ overlying coal seam.

Granulatisporites spp. L, PZ, P, S, J. ø 5\%; max. 17\% - PZ.

Grumosisporites spp. L, PZ. ø 1.3\%; max. 3\% - 1 $1^{\text {st }}$ Žd'árky Coal Seam.

Güthoerlisporites magnificus Bharadwaj, 1957. J.

Guthoerlisporites spp. J. ø 4\%; max. 8\% - Radvanice coal seams.

Illinites spp. J. ø 4\% (only one record).

Illinites unicus (Kosanke) Bharadwaj, 1957. J. ø 1\%.

Knoxisporites polygonalis (Ibrahim) Potonié \& Kremp, 1955. L, PZ, P. ø 4.3\%; max. 12\% - between $14^{\text {th }}$ and $13^{\text {th }}$ Lampertice coal seams.

Knoxisporites spp. L, PZ. ø $1 \%$; max. 3\% - $9^{\text {th }}$ overlying coal seam.

Kosankeisporites elegans (Kosanke) Bharadwaj, 1957. J, V. ø 1.4\%; max. 5\% - Radvanice coal seams.

Kosankeisporites spp. S, J, O. ø 2.5\%; max. 4\% - Na Rybníčku Coal Seam.

Kuhlensisporites spp. PZ. ø 1\% (only one measured record).

Laevigatosporites costatus Alpern, 1959. J.

Laevigatosporites densus Alpern, 1959. J, V.

Laevigatosporites desmoinesensis (Wilson \& Coe) Schopf, Wilson \& Bentall, 1944. L, PZ, P, S, J, V. ø 17\%; max. 54\% - Pulkrábek Coal Seam.

Laevigatosporites maximus (Loose) Potonié \& Kremp, 1955. L, PZ, P, S, J, V. ø 2.3\%; max. 5\% - Radvanice coal seams.

Laevigatosporites medius Kosanke, 1950. L, PZ, P, S, J, V. ø 12\%; max. 82\% - Radvanice coal seams.

Laevigatosporites minimus (Wilson \& Coe) Schopf, Wilson \& Bentall, 1944. L, PZ, S, J, V. ø 14\%; max. 77\% - Baltazar Coal Seam.

Laevigatosporites striatus Alpern, 1959. S, J, V. ø 0.5\% (only one record).

Laevigatosporites vulgaris Ibrahim, 1933. S, J. ø 4.9\%; max. 16\% - Baltazar Coal Seam.

Latensina spp. J. ø 2.8\%; max. 7\% - Radvanice coal seams.

Latensina triletus Alpern, 1959. J. ø 3\%; max. 4\% - Radvanice coal seams.

Latosporites globosus Schemel, 1950. J. ø 9\% (only two records); max. 16\% - Radvanice coal seams.

Latosporites latus (Loose) Potonié \& Kremp, 1955. L, PZ, P, S, J, V. ø 4.2\%; max. 16\% - 9 $9^{\text {th }}$ overlying coal seam.

Latosporites melnicensis Kalibová, 1989. J.

Latosporites robustus (Kosanke) Potonié \& Kremp, 1955. P, S, J. ø 1.8\%; max. 3\% - Radvanice coal seams.

Latosporites saarensis Bharadwaj, 1955. J, V. ø 6.1\%; max. 19\% - Radvanice coal seams.

Latosporites spp. L, PZ. ø 1.8\%; max. 3\% - S.

Leiotriletes adnatoides Potonié \& Kremp, 1955. L, PZ, P, S, J. ø 4.5\%; max 20\% - Petrovice Coal Seam.

Leiotriletes adnatus Kosanke, 150. L, PZ, P. ø 12\% (only two occurrences); max. $13^{\text {th }}-14^{\text {th }}$ overlying seam.

Leiotriletes convexus (Kosanke) Potonié \& Kremp, 1955. L, PZ, P, S. ø 5\%; max. 25\% at the base of P.

Leiotriletes gulaferus Potonié \& Kremp, 1955. L, PZ, P, S, J. ø 4.3\%; max. 25\% at the base of P.

Leiotriletes minutus (Knox) Potonié \& Kremp, 1955. L, PZ, P, S. ø 8\%; max. 3\% - $10^{\text {th }}$ underlying seam.

Leiotriletes sphaerotriangulus (Loose) Potonié \& Kremp, 1955. L, PZ, P, S, J. ø 4.3\%; max. 11\% - 2 $2^{\text {nd }}$ Ždárky Coal Seam.

Leiotriletes spp. L, PZ, P, S, J. ø 4.7\%; max. 17\% - P.

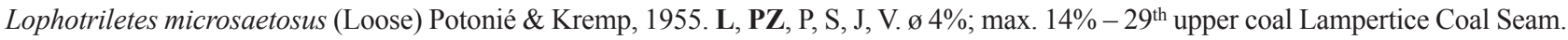


Lophotriletes cf. microsaetosus (Loose) Potonié \& Kremp, 1955. PZ, P, S, J.

Lophotriletes commisuralis (Kosanke) Potonié \& Kremp, 1955. L PZ, P, S, J. ø 3.5\%; max. 6\% - the "Visutá" Coal Seam.

Lophotriletes f. gulaferus. L, PZ, P, S. J, V.

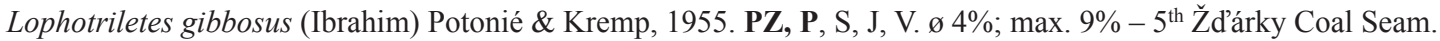

Lophotriletes insignitus (Ibrahim) Potonié \& Kremp, 1955. L, V. ø 2.5\%; max. 5\% - $9^{\text {th }}$ Lampertice Coal Seam (only two measured records).

Lophotriletes mosaicus Potonié \& Kremp, 1955. L, PZ, P, S, J, V, O. ø 3.5\%; max 9\% - Petrovice Coal Seam.

Lophotriletes pseudaculeatus Potonié \& Kremp, 1955. PZ, P, S, J. ø 1\%.

Lophotriletes spp. L, PZ, P, S, J. ø 3.5\%; max. 14\% - 11 $1^{\text {th }}$ Lampertice Coal Seam.

Lophozonotriletes spp. L, PZ, ø $0.5 \%$ (only one measured record).

Lueckisporites spp. J. ø 0.3\% (only one record).

Lundbladispora gigantea (Alpern) Doubinger, 1961. J.

Lycospora brevijuga Kosanke, 1950. L, PZ, P, S, J. ø 9.5\%; max. 36\% - Radvanice coal seams.

Lycospora brevis Bharadwaj, 1957. L, PZ, P, S, J. ø 10\%; max. 33\% - 9 $9^{\text {th }}$ Lampertice Coal Seam.

Lycospora granulata Kosanke, 1950. PZ, P, S, J, V. ø 4.6\%.

Lycospora microgranulata Bharadwaj, 1957. S. ø 1\%.

Lycospora noctuina Butterworth \& Williams, 1958. L, PZ, P, S, J, V. ø 4.8\%; max. 2\% - Jan Šverma Mine.

Lycospora parva Kosanke, 1950. L.

Lycospora pellucida (Wicher) Schopf, Wilson \& Bentall, 1944. L, PZ, S. ø 1.8\%; max. 10\% - Jan Šverma Mine.

Lycospora pseudoannulata Kosanke, 1950. L, PZ, S, J, V.ø 12\%; max. 31\% - $1^{\text {st }}$ Žd'árky Coal Seam.

Lycospora punctata Kosanke, 1950. L, PZ, P, S, J, V. ø 20\%; max 96\% - Jan Šverma Mine.

Lycospora pusilla (Ibrahim) Potonié \& Kremp, 1955. L, PZ, P, S, J. ø 18\%; max. 75\% - base S.

Lycospora rotunda Bharadwaj, 1957. L. ø 17\% (only one record).

Lycospora spp. L, PZ, P, S, J, V, O. ø 25\%, max. 91\% 33 rd overlying Coal Seam, $100 \% 2^{\text {nd }}$ overlying coal seam.

Lycospora subjuga Bharadwaj, 1957. L, PZ, P, S, J. ø 5.5\%; max. 34\% - 3 ${ }^{\text {rd }}$ Žd'árky Coal Seam.

Lycospora triangulata Bharadwaj, 1957. PZ, P. ø 3\%; max. 6\% - 5

Microreticulatisporites fistulosus (Ibrahim) Potonié \& Kremp, 1955. L, PZ, P, S, J, V. ø 3\%; max. 14\% - $11^{\text {th }}$ Lampertice Coal Seam.

Microreticulatisporites nobilis (Wicher) Knox, 1950. PZ, P, S, J. ø 3\%; max. 7\% - Main Svatoňovice Seam.

Microreticulatisporites punctatus Knox, 1950. L. ø 2.5\%; max. 12\% - Jan Šverma Mine.

Microreticulatisporites reticuloides (Kosanke) Potonié \& Kremp, 1955. L.

Microreticulatisporites sulcatus (Wilson \& Kosanke) Smith \& Butterworth, 1967. L, PZ.

Microreticulatisporites spp. L, PZ, P, S, J.

Mooreisporites cf. inusitatus (Kosanke) Neves, 1961. PZ.

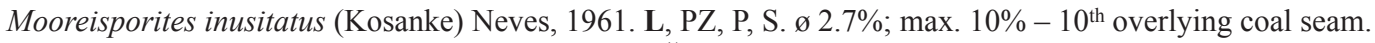

Mooreisporites spp. L, PZ. ø 4.9\%; max. 17\% - Jan Šverma Mine.

Murospora spp. L, PZ. ø 4.5\%; max. 20\% - $6^{\text {th }}$ underlying coal seam.

Murospora sulcata (Waltz) Jachowicz, 1972. L. ø 5\% (only one measured record).

Planisporites spp. L, PZ, P, S, J.ø 2.7\%; max. 16\% - upper Lampertice Coal Seam.

Polymorphisporites spp. L, PZ, P, S, J. ø 0.5\%.

Potonieisporites novicus Bharadwaj, 1957. J, V, O. ø 1.2\% max. 2\% - Radvanice coal seams.

Potonieisporites spp. J, V. ø 2\%; max 9\% - Radvanice coal seams.

Potoniesporites elegans (Wilson \& Kosanke) Wilson \& Venkatachala, 1964. J, V. ø 0.3\%.

Punctatisporites aerarius Butterworth \& Williams, 1958. L. ø 1\% (only one record).

Punctatisporites minutus Kosanke, 1950. L, PZ, P, S, J, V. ø 2\%; max. 7\% - 25 $5^{\text {th }}$ overlying seam.

Punctatisporites obesus (Loose) Potonié \& Kremp, 1955. PZ, P, S. ø 1\%.

Punctatisporites obliquus Kosanke, 1950. L, PZ, P, S, J, V. ø 2\%; max. 5\% - $2^{\text {nd }}$ Žd'árky Coal Seam.

Punctatisporites provectus Kosanke, 1950. V. ø 1\%.

Punctatisporites punctatus Ibrahim, 1933. L, PZ, P, S. ø 2.5\%; max. 4\% - "Visutá" Coal Seam.

Punctatisporites spp. L, PZ, P, S, J, V. ø $2.3 \%$; max. $10 \%-8^{\text {th }}$ overlying coal seam.

Punctatosporites bechlinensis Kalibová, 1989. J. ø 1.5\%; max. 2\% - Radvanice coal seams.

Punctatosporites granifer Potonié \& Kremp, 1955. PZ, P, S, J. ø 7\%; max. 23\% - Main Svatoňovice Coal Seam.

Punctatosporites granulatus Bharadwaj, 1957. S, O. ø 4\% (only one measured record).

Punctatosporites minutus Ibrahim, 1933. L, PZ, S, J, V. ø 6\%; max. 32\% - $8^{\text {th }}$ Žd'árky Coal Seam.

Punctatosporites oculus Smith \& Butterworth, 1967. J. ø 2.5\%; max. 6\% - Baltazar Coal Seam.

Punctatosporites punctatus (Kosanke) Potonié \& Kremp, 1955. PZ, P, S, J. ø 5.5\%; max. 18\% - 8 Žd'árky Coal Seam.

Punctatosporites pygmaeus (Imgrund) Potonié \& Kremp, 1955. S, J. ø 24\% (only one measured record).

Punctatosporites rotundus (Bharadwaj) Dybová \& Jachowicz, 1957. S, J. ø 3\% (only one measured record). 
Punctatosporites speciosus Kalibová, 1989. J. ø 2\%; max. 4\% - Radvanice coal seams.

Punctatosporites spp. L, PZ, P, S, J, V.ø 9\%; max. 50\% - Jan Šverma Mine.

Pustulatisporites pustulatus Potonié \& Kremp, 1955. L, PZ, P, S, J. ø 3.8\%; max. 8\% - 5 th $^{\text {Z }}$ d'árky Coal Seam.

Pustulatisporites spp. L, PZ, P, S, J. ø 1.3\%; max. 3\% - Jan Šverma Mine.

Radiizonates spp. L.

Raistrickia aculeata Kosanke, 1950. J.

Raistrickia aculeolata Kosanke, 1950. J, V.

Raistrickia carbondalensis Peppers, 1970. L.

Raistrickia crinita Kosanke, 1950. L, PZ, P, S. ø 2.2\%; max. 3\% - "Visutá" Coal Seam.

Raistrickia fulva Artüz, 1957. L.

Raistrickia microhorrida (Horst) Potonié \& Kremp, 1955. L.

Raistrickia saetosa (Loose) Schopf, Wilson \& Bentall, 1944. L, PZ, P, S, J. ø 1.7\%; max. 5\% - 5 $5^{\text {th }}$ Ždárky Coal Seam.

Raistrickia spp. L, PZ, P, S, J. ø 2\%; max. 12\% - 2 $2^{\text {nd }}$ Žd'árky Coal Seam.

Raistrickia superba (Imgrund) Schopf, Wilson \& Bentall, 1944. L, PZ, P, S. ø 2.8\%; max. 16\% - upper part of L.

Reinschospora magnifica Kosanke, 1950. L, PZ.

Reinschospora spp. L, PZ. ø $0.5 \%$.

Remysporites magnificus (Horst) Potonié \& Kremp, 1955. L.

Reticulatasporites facetus Ibrahim, 1933. L, PZ. ø 5\%; max. 11\% - base of P.

Reticulatasporites spp. PZ, P, S.

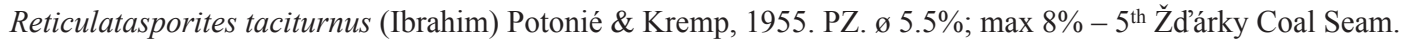

Reticulatisporites adhaerens Kosanke, 1950. L, PZ.ø 2\% (only one measured record).

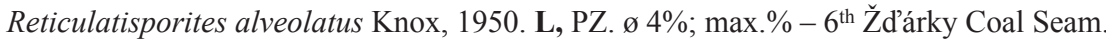

Reticulatisporites castaneaeformis (Horst) Sullivan, 1964. L, PZ. ø 4.5\%; max. 14\% - 2 $2^{\text {nd }}$ Žd'árky Coal Seam.

Reticulatisporites reticulatus Ibrahim, 1933. PZ, P, S, J, V. ø 2\% (only one measured record).

Reticulatisporites reticulocingulum (Loose) Ravn, 1986. L, PZ, P, S, J, V.

Reticulatisporites spp. L, PZ, P, S, J, V, O. ø $3.5 \%$.

Savitrisporites camptotus (Alpern) Doubinger, 1974. L, PZ. 3.5 ; max. 11\% - L.

Savitrisporites cingulatus (Alpern) Bharadwaj, 1962. L, PZ, P. ø 4.2\%; max. 11\% - 2 ${ }^{\text {nd }}$ Žd'árky Coal Seam.

Savitrisporites concavus Marshall \& Smith, 1965. L, PZ. ø 7.5\%; max. 24\% - 6 $6^{\text {th }}$ underlying coal seam.

Savitrisporites majus Bharadwaj, 1958. L.

Savitrisporites minor Jachowicz, 1972. L, PZ, P, S. ø 12\%; max. 53\% - 2nd overlying coal seam.

Savitrisporites nux (Butterworth \& Willimas) Smith \& Butterworth, 1967. L, PZ. ø 8.8\%; max. 45\% - 17 $7^{\text {th }}$ underlying coal seam.

Savitrisporites spp. L, PZ, P, S. ø 4.5\%; max. 31\% - upper part of L.

Simozonotriletes clarus Dybová \& Jachowicz, 1957. PZ.

Simozonotriletes intortus (Waltz) Potonié \& Kremp, 1955. L, PZ.

Simozonotriletes spp. L, PZ. ø 2.6\%; max. 7\% - between $22^{\text {nd }}$ and $23^{\text {rd }}$ underlying coal seams.

Sinuspores sinuatus (Artüz) Ravn, 1986. L, PZ. ø 3.5\%; max. 20\% - $18^{\text {th }}$ underlying coal seam.

Speciososporites laevigatus Alpern, 1959. S, J. ø 3.5\%; max. 16\% - Radvanice coal seams.

Speciososporites minor Alpern, 1957. J, V. ø 4.5\%; max. 7\% - Radvanice coal seams.

Speciososporites plicatus Alpern, 1957. J. ø 2.3\%; max. 3\% - Radvanice coal seams.

Speciososporites spp. S, J, V. ø 3\%; max. 14\% - Radvanice coals seams.

Speciososporites triletoides Alpern, 1959. J.

Spinosporites spinosus Alpern, 1959. V. ø 4\% (only one measured record).

Stellisporites cf. inflatus Alpern, 1959. L, PZ.

Stellisporites inflatus Alpern, 1959. L, PZ.

Stellisporites spp. L, PZ. ø $1.2 \%$.

Stenozonotriletes commendatus Ischenko, 1956. L. ø 1\%.

Stenozonotriletes lycosporoides (Butterworth \& Williams) Smith \& Butterworth, 1967. PZ.

Stenozonotriletes reticulatus Naumova, 1953. L. ø 1\% (only one measured record).

Stenozonotriletes spp. L. ø $2 \%$; max. $3 \%-27^{\text {th }}$ overlying and $21^{\text {st }}$ underlying coal seams.

Thymospora obscura (Kosanke) Wilson \& Venkatachala, 1964. P, S, J. ø 1\% (only one measured record).

Thymospora spp. L, PZ, P, S, J. ø 2.4\%; max. 11\% - Radvanice coal seams.

Thymospora thiessenii (Kosanke) Wilson \& Venkatachala, 1964. J. ø 1\%.

Thymospora verrucosa (Alpern) Wilson \& Venkatachala, 1964. V. ø 1\% (only one measured record).

Torispora granulata Alpern, 1959. S. ø 5\%.

Torispora securis Balme, 1952. PZ, P, S, J. ø 4\%; max. 14\% - lower part of the Radvanice coal seams.

Torispora spp. S, J. ø 9\%, max. 50\% lower part of S. 
Torispora undulata Dybová \& Jachowicz, 1957. S. ø 2\%.

Tripartites spp. PZ. ø 1\% (only one record).

Triquitrites auriculatus Bharadwaj, 1957. L.

Triquitrites bransonii Wilson \& Hoffmeister, 1956. S, J. ø 4.6\%.

Triquitrites exiquus Wilson \& Kosanke, 1944. S, J. ø 6\%; max. 14\% - Main Svatoňovice Coal Seam.

Triquitrites minutus Alpern, 1959. L, PZ, P, S, J. ø 4.5\%; max. 16\% - middle of P.

Triquitrites pulvinatus Kosanke, 1950. S. ø 5\%; max. 10\% - base of S.

Triquitrites sculptilis Balme, 1952. L, PZ, P, S, J. ø 4.5\%; max. 17\% - Petrovice Coal Seam.

Triquitrites spp. L, PZ, P, S, J. ø 4.1\% max. 50\% - lower part of S.

Triquitrites tribullatus (Ibrahim) Schopf, Wilson \& Bentall, 1944. PZ.

Triquitrites tricuspis (Horst) Potonié \& Kremp, 1955. L, PZ. $\varnothing .7 \%$; max. $-17 \% 16^{\text {th }}$ underlying coal seam.

Triquitrites tripartitus Alpern, 1959. L, PZ, P, S. ø 4\%; max. 5\% - 10 th overlying coal seam.

Triquitrites triturgidus (Loose) Potonié \& Kremp, 1955. L, PZ, P, S, J, V. ø 2\% (only one measured record).

Tuberculatosporites sp. A Kalibová, 1989. J, V.

Variouxisporites plicatus Alpern, 1959. S, J, V.

Variouxisporites spp. P, S, J, V.ø 3\%; max. 17\% - Petrovice Coal Seam.

Verrucosisporites donarii Potonié \& Kremp, 1955. J. ø 3\%; max. 4\% - Radvanice coal seams.

Verrucosisporites grandiverrucosus (Kosanke) Smith et al. 1964. J. ø 3.3\%.

Verrucosisporites microtuberosus (Loose) Potonié \& Kremp, 1955. L, PZ, P, J. ø 3\%; max. 11\% - base of P.

Verrucosisporites sinensis Imgrund, 1960. S, J, V.ø 4\%; max. 13\% - Radvanice coal seams.

Verrucosisporites spp. L, PZ, P, S, J, V. ø 3\%; max. 14\% - S.

Verrucosisporites verrucosus Ibrahim, 1933. J. ø 2\% (only one record).

Vestispora cancellata Dybová \& Jachowicz, 1957. L, PZ. ø 4.6\%; max. 10\% - $4^{\text {th }}$ Žd'árky Coal Seam.

Vestispora costata (Balme) Bharadwaj, 1957. L, PZ, P, S. ø 4\%.

Vestipora fenestrata (Kosanke \& Brokaw) Spode in Smith \& Butterworth, 1967. L, PZ, P, S. ø 9\%; max. 18\% - Main Svatoňovice Coal Seam.

Vestispora laevigata Wilson \& Venkatachala, 1963. PZ.

Vestispora magna (Butterworth \& Williams) Spode in Smith \& Butterworth, 1967. PZ. $\varnothing \%$ (only one measured record).

Vestispora pseudoreticulata Spode in Smith \& Butterworth, 1967. L, PZ. ø 7\%; max. 11\% - 2 $2^{\text {nd }}$ Žd'árky Coal Seam.

Vestispora quaesita (Kosanke \& Brokaw) Wilson \& Venkatachala, 1963. PZ, P, S. ø 4\%; max. 12\% - "Visutá" Coal Seam.

Vestispora spp. L, PZ, P, S, J, V, O. ø $1.3 \%$; max. 5\% - $17^{\text {th }}$ underlying coal seam.

Vestispora tortuosa (Balme) Bharadwaj, 1957. PZ. ø 3\% (only one measured record).

Vittatina spp. P, S, V, J.

Waltzispora spp. L. ø 1\% (only one measured record).

Westphalenisporites spp. PZ, P. ø 1.8\%; max. 3\% - P.

Westphalensisporites irregularis Alpern, 1959. PZ, P, S, J. ø 8\%; max. 52\% - Petrovice Coal Seam.

Wilsonites delicatus Kosanke, 1950. S, J, V.ø 2.5\%; max. 5\% - Radvanice coal seams.

Wilsonites kosankei Bharadwaj, 1957. S.

Wilsonites spp. PZ, P, S, J. ø 2\%; max. 11\% - Radvanice coal seams.

Wilsonites vesicatus Kosanke, 1950. J. ø 3\%; max. 5\% - Radvanice coal seams.

\section{Electronic supplement 1}

The occurrence of dispersed miospores and pollen in the Czech part of the Intra-Sudetic Basin. Palynospecies are plotted against the stratigraphic column with resolution of individual fossiliferous horizons. Legend: 1 - presence of the taxon; $0-$ absence of the taxon. Empty fields between the first and last occurrence of any the taxon were filled by 1 , based on assumption of continuous presence of the species in the study area, although it has not been found.

\section{Electronic supplement 2}

The percentage of dispersed miospore and pollen genera in the Czech part of the Intra-Sudetic Basin. Legend: 0 - genus does not occur or reaches less than $1 \%$. 